IZA DP No. 9260

Reducing Risks in Wartime Through

Capital-Labor Substitution:

Evidence from World War II

Chris Rohlfs

Ryan Sullivan

Thomas J. Kniesner

August 2015 


\title{
Reducing Risks in Wartime Through Capital-Labor Substitution: Evidence from World War II
}

\author{
Chris Rohlfs \\ Morgan Stanley \\ Ryan Sullivan \\ Naval Postgraduate School \\ Thomas J. Kniesner \\ Claremont Graduate University, \\ Syracuse University (Emeritus) and IZA
}

Discussion Paper No. 9260

August 2015

\author{
IZA \\ P.O. Box 7240 \\ 53072 Bonn \\ Germany \\ Phone: +49-228-3894-0 \\ Fax: +49-228-3894-180 \\ E-mail: iza@iza.org
}

Any opinions expressed here are those of the author(s) and not those of IZA. Research published in this series may include views on policy, but the institute itself takes no institutional policy positions. The IZA research network is committed to the IZA Guiding Principles of Research Integrity.

The Institute for the Study of Labor (IZA) in Bonn is a local and virtual international research center and a place of communication between science, politics and business. IZA is an independent nonprofit organization supported by Deutsche Post Foundation. The center is associated with the University of Bonn and offers a stimulating research environment through its international network, workshops and conferences, data service, project support, research visits and doctoral program. IZA engages in (i) original and internationally competitive research in all fields of labor economics, (ii) development of policy concepts, and (iii) dissemination of research results and concepts to the interested public.

IZA Discussion Papers often represent preliminary work and are circulated to encourage discussion. Citation of such a paper should account for its provisional character. A revised version may be available directly from the author. 


\section{ABSTRACT}

\section{Reducing Risks in Wartime Through Capital-Labor Substitution: Evidence from World War II}

Our research uses data from multiple archival sources to examine substitution among armored (tank-intensive), infantry (troop-intensive), and airborne (also troop-intensive) military units, as well as mid-war reorganizations of each type, to estimate the marginal cost of reducing U.S. fatalities in World War II, holding constant mission effectiveness, usage intensity, and task difficulty. If the government acted as though it equated marginal benefits and costs, the marginal cost figure measures the implicit value placed on soldiers' lives. Our preferred estimates indicate that infantrymen's lives were valued in 2009 dollars between $\$ 0$ and \$0.5 million and armored troops' lives were valued between $\$ 2$ million and \$6 million, relative to the efficient $\$ 1$ million to $\$ 2$ million 1940s-era private value of life. We find that the reorganizations of the armored and airborne divisions both increased efficiency, one by reducing costs with little increase in fatalities and the other by reducing fatalities with little increase in costs.

JEL Classification: H56, J17, N42, D24, J24, L11

Keywords: $\quad$ cost of saving lives, World War II, military cost functions, military capital-labor substitution, European theater of operation

Corresponding author:

Thomas J. Kniesner

Claremont Graduate University

Harper East 216

Claremont, CA 91711

USA

E-mail: thomas.kniesner@cgu.edu

\footnotetext{
* The views expressed here are those of the authors and do not reflect the official policy or position of the Department of Defense or the U.S. Government. Distribution for this article is unlimited. Special thanks for generous financial assistance from the National Bureau of Economic Research and the Maxwell School of Syracuse University and for data generously provided by The Dupuy Institute. Thanks also for expert research assistance provided by Jeremy Goucher, Siddhartha Gottipamula, Caleb Sheldon, Melanie Zilora, the National Archives and Records Administration, and Santosh Gurlahosur and Ashim Roy of Comat Technologies. This paper benefited very much from help and guidance from people too numerous to list but particularly from Michael Greenstone, Mark Duggan, Steve Levitt, and Casey Mulligan, and from Richard Anderson, Marty Feldstein, Rodney Row, Chris Lawrence, and an anonymous referee.
} 


\section{Introduction}

Governments spend large amounts each year to increase the safety and effectiveness of ground combat troops; however, little is known about the degree to which their expenditures translate into measureable improvements in survival or combat success. Our research uses data from multiple archival sources to understand the economics of ground combat and tradeoffs made by American military planners between expenditures and U.S. deaths in one important historical context -the Western Front of World War II (WWII). The cost per life saved is estimated and used to infer the dollar value that the U.S. government placed on avoiding military deaths and determine how that valuation compared with the private Value of a Statistical Life (VSL) at the time - citizens' willingness to pay for reductions in fatality risk (Thaler and Rosen, 1975; Viscusi, 1993, 1996).

U.S. Army Ground Forces were organized into divisions, military units consisting of 8,000 to 20,000 troops, that were infantry (troop-intensive), armored (tank-intensive), or airborne (paratrooper, also troop-intensive). In late 1943, Army policies reduced the size of the armored division and slightly reduced the size of the infantry division. In early 1945, another Army policy increased the size of the airborne division. Our research considers the effects of substitution across the different pre- and post-reorganization division types. Tank-intensive units were expensive in dollars, but troop-intensive units put more human targets on the battlefield; hence, an increase in tank-intensity would raise dollar costs and reduce fatalities. If the U.S. government acted as though it equated marginal benefits and marginal costs, the marginal cost per reduction in fatalities measures the implicit value the government placed on soldier's lives.

We compiled the data set we use from multiple sources, and it constitutes the most extensive set of quantitative information available on military operations in a single war. 
Included are individual-level data on all 144,534 deaths to American ground divisions in WWII that were hand-typed from archival lists and combined with casualty rosters obtained from multiple government agencies. All Allied and Axis units' movements come from campaign histories and historical atlases to identify terrain, geographical progress, and which Allied and Axis units met in combat. Another set of archival sources we compiled measure the costs of raising and operating different U.S. divisions in WWII. Finally, we also use data compiled by The Dupuy Institute from U.S. and German archival sources on both sides' combat experiences for 162 engagements.

The results from our research indicate that, at the tank-intensity levels of the infantry and airborne divisions, the marginal cost in 2009 dollars per life saved by increasing tank intensity was $\$ 0.5$ million or less, as compared to VSL estimates of \$1 million to \$2 million for young men in 1940 (Costa and Kahn, 2004). At the higher tank-intensity level of the armored division, we find a higher cost per life saved that is generally greater than $\$ 2$ million. Thus, our results suggest that the U.S. government implicitly undervalued infantrymen's lives and slightly overvalued armored personnel's lives relative to the private value of citizens at the time. We find that the reorganization of the armored division increased efficiency by reducing dollar costs with little increase in fatalities and that the reorganization of the airborne division increased efficiency by generating a large reduction in fatalities at a low cost.

It is important to recognize that our research does not directly estimate the VSL for U.S. military personnel during WW II. It is more akin to the cost per life saved estimates used for various government regulations (Morrall III 2003). It is unclear whether military members at the time valued their lives differently in comparison to non-military workers. Given the widespread reach of the draft, it is likely that they were roughly the same. There does not appear to be any 
previous research on estimating the VSL for WW II military personnel. As for other conflicts, Rohlfs (2012) estimates an upper bound on the VSL for military recruits during the Vietnam era and finds values ranging from $\$ 7$ million to $\$ 12$ million (in 2009 dollars). In addition, recent estimates from Greenstone et al. (2014) suggest that modern day military members tend to implicitly value their lives at levels lower than average citizens. Also, given the limited amount of applicable research, it is not entirely clear whether military members have traditionally been under- or over-valued by the U.S. government relative to private citizens. Recent estimates in Rohlfs and Sullivan (2013), for modern day warfare, suggest that the U.S. government likely over-values military members in comparison to average citizens for certain types of armament programs. Recent relative over-valuation of life saving in the military may or may not be the case historically, and our research provides context for issues related to the economics of military decisions where soldiers' lives are at stake. ${ }^{1}$

\section{Key Institutional Factors}

After World War I, British military theorists advocated increasing the use of tanks to avoid the casualty-intensive stalemate of trench warfare (Fuller, 1928, pp. 106-151; Liddell Hart, 1925, pp. 66-77; Wilson, 1998, pg. 120). The British theorists' ideas were influential in the U.S. Army and in Congress (U.S. Congress, 1932, pg. 9932). However, the Army was slow to adopt tanks due to conservatism among high-ranking officers and Congressional budget cuts (Greenfield, Palmer, and Wiley, 1947, pp. 334-335; Steadman, 1982; Watson, 1950, pp. 15-50).

\footnotetext{
${ }^{1}$ In addition to addressing the U.S. government's implicit valuation of soldiers' lives, our study adds to the tools available for empirical research in national defense. The WWII data used here describe a wide variety of combat situations and are unique among datasets from modern wars in that they include detailed first-hand information from both sides. Casualty forecasts using previously available WWII data have been more accurate than those based on less data-driven approaches (Economist, 2005), and the data and techniques we introduce here could help to further improve the accuracy of many types of military resource deployment policy evaluations.
} 


\section{A. Determinants of Army-Wide Capital Intensity During World War II}

During the war, military procurement was constrained by the size of the U.S. economy and population (Smith, 1959, pp. 136; 154-158); however, the procurement process was driven more by planners' perceived tradeoffs than by responses to immediate shortages (Harrison, 1988, pp. 181, 188-9). Constraints that the War Production Board imposed on materiel procurement were denominated in dollars and took into account "the needs of the civilian and industrial economy" (Smith, 1959, pg. 154-8). Most materiel purchases involved large contracts whose prices were monitored to curb war profiteering (Smith, 1959, pp. 216-412) but appear to have been somewhat higher than prices in the civilian economy. ${ }^{2}$

As with equipment, troop procurement involved a variety of tradeoffs. The Army adjusted its new soldiers' physical and intellectual competency requirements depending on the need for troops, and Congress restricted the drafting of 18 -year-olds and fathers in response to public sympathy but varied draftee restrictions depending on the needs of the war effort (Greenfield, Palmer, and Wiley, 1947, pp. 246-251; Palmer, Wiley, and Keast, 1959, pp. 45, 85, 201-207, 400).

\section{B. Division Types and the Reorganizations}

The division was the primary level at which U.S. Army Ground Forces were organized. Roughly two to four divisions comprised a corps, which was the next higher level of organization. Divisions from the same corps were rarely more than a few miles apart. Divisions'

\footnotetext{
${ }^{2}$ With all prices in 2009 dollars, in 1942, the Army paid \$18,300 for a four-door sedan and $\$ 16,000$ for a $1 / 4$-ton jeep (U.S. Army Service Forces, 1942). One source shows a new two-door sedan selling in the civilian economy in 1940 for $\$ 11,300$; comparable new and used cars sold in nearby years for similar prices. In 1935, a used half-ton pickup truck was selling for $\$ 7,300$, and in 1956 , a new jeep was selling for $\$ 10,800$ (Morris County Library, 2009).
} 
corps affiliations changed frequently over the course of the war, and a corps sometimes included divisions from multiple countries (Greenfield, Palmer, and Wiley, 1947, pg. 332; Kahn and McLemore, 1980, pp. 192-199).

The Army sent 16 armored divisions, 47 infantry divisions, and 4 airborne divisions to the Western Front. Offensively, armor use could exploit penetrations generated by infantry and often operated behind enemy lines but required large amounts of gasoline and had difficulty on wet or rugged terrain. A wide set of both offensive and defensive operations used infantry, and airborne divisions parachuted behind enemy lines to disrupt communications and supplies and to initiate surprise attacks (Evans, 2002, pg. 49; Gabel, 1985a, pg. 4-6, 24; 1985b, pg. 4, 1986, pp. 4, 8, 12, 23; Rottman, 2006, pp. 6, 24-7; Stanton, 1984, pg. 8, 11; Zaloga, 2007, pp. 9-12).

Technological progress at the time allowed U.S. commanders to advance and maneuver their troops much faster during WW II than in previous wars. The degree of movement, however, was largely dictated by the terrain, combat environment, and unit capabilities. The initial entry of U.S. forces into the war began in November, 1942 in Algeria and Morocco. Units traveled east across Africa, up to Tunis and Sicily, and continued up the length of Italy for the duration of the war. Additional Allied units invaded Northern France in June 1944 and Southern France in August 1944, both traveling eastward to Germany.

When the U.S. first entered the war, the number of troops in a standard infantry division was 15,514 , and the number in a standard armored division was slightly lower, at 14,643; the armored division also included 390 tanks. The airborne division was first introduced in October 1942 and included 8,505 troops, making it considerably smaller than the other division types. The actual numbers of troops and tanks in a division varied over time as subordinate units, such as regiments and battalions, were attached to and detached from different divisions. Attaching 
units was more common than detaching them, so that the numbers of troops and tanks in a division tended to be larger than the standard levels. Troops and tank levels also varied due to the lag between combat losses and the arrival of replacement troops and equipment.

In July 1943 the Army slightly reduced the size of the infantry division to 14,253 . In September 1943 the Army reduced the troops and tanks in the armored division to 10,937 and 263. In December 1944 the Army increased the number of troops in an airborne division to 12,979 (Wilson, 1998, pp. 162-9, 183-5, 197). The new structures help identify the military's implicit value of soldiers' lives.

All armored and infantry divisions that were raised after the reorganizations were given the new structure. All six infantry divisions already in the theater were reorganized in late 1943 or early 1944 . Of the three armored divisions that were already in the theater, the $1^{\text {st }}$ was reorganized in June, 1944. The $2^{\text {nd }}$ and $3^{\text {rd }}$ were kept under the old structure to avoid disrupting their preparation for the D-Day invasion and were not reorganized until after the end of the war. The airborne reorganizations all took place on March 1, 1945. Of the four airborne divisions -the $13^{\text {th }}, 17^{\text {th }}, 82^{\text {nd }}$, and $101^{\text {st }}$-that were sent to the Western Front, the attachments to the $82^{\text {nd }}$ and $101^{\text {st }}$ were sufficiently large prior to the reorganization that they were effectively under the larger structure since the start of the war (Stanton, 1984, pp. 5-19; Wilson, 1998, pp. 182-96).

\section{Descriptive Results}

The datasets we use here include a daily panel constructed by us and a team of research assistants. The data include information about the overseas experiences of every U.S. division sent to the Western Front and a sample obtained from The Dupuy Institute of a more detailed set of variables for 289 division days from 162 engagements between U.S. and German forces. In 
addition, our research team compiled data from archival sources on the costs of raising and operating divisions of different types. Descriptions and summary statistics for all our datasets appear in the Appendix.

Figure 1 shows numbers of U.S. troops, tanks, estimated cost, and combat outcomes by division type. Panels A and B show actual troop and tank levels from the engagement data. Within each panel the left three bars are pre-reorganization levels and the right three bars are post-reorganization. The black bars correspond to armored divisions, the white bars to infantry divisions, and the gray bars to airborne divisions. The $2^{\text {nd }}$ and $3^{\text {rd }}$ Armored Divisions are always treated as pre-reorganization, and the $82^{\text {nd }}$ and $101^{\text {st }}$ Airborne Divisions are always treated as post-reorganization.

As the engagement data illustrate, reorganization led to considerably smaller armored divisions. The reorganization reduced the typical armored division's numbers of troops and tanks from 20,000 and 467 to 15,100 and 218 . This was in stark contrast to the impact of the reorganization's effect on the size of other division types. For instance, the reorganization appears to have had little impact on the size of infantry divisions. The engagement data do not include information on the size of the pre-reorganization airborne units. We do find, however (in results not shown), that the standard and authorized troop level data indicate that the reorganization led to considerably larger airborne divisions.

Panel C combines the per troop and per tank estimates from the cost data with the troop and tank levels from panels A and B to estimate the cost of a 10.8-month deployment by division type. ${ }^{3}$ From the engagement data, we find that the 1943-1944 armored reorganization reduced

\footnotetext{
${ }^{3}$ Light, medium, and heavy tanks are all treated equally in the cost calculations. The U.S. Army increased its percentage of medium versus light tanks over the course of the war and introduced a heavy tank design near the end of the war (Stubbs and Connor, 1969, pp. 63-6). In the engagement data, considering light tanks separately from medium and heavy tanks has little effect on the estimates in this study, as shown in the Appendix.
} 
the cost of an armored division from $\$ 5.14$ billion to $\$ 2.93$ billion (\$2009) and that the infantry reorganization slightly increased the cost of an infantry division from $\$ 2.20$ billion to $\$ 2.29$ billion (\$2009) for a 10.8 month deployment.

Panels D, E, and F present various measures illustrating how well U.S. troops performed in combat. Success measures include kilometers $(\mathrm{km})$ of progress along the attacker's axis of advance, U.S. killed in action (KIA), and a zero to one subjective index of mission success from The Dupuy Institute (2001b, 2005) for each of the division types. The differences between armored and infantry divisions in the panels suggest that armor was more effective than infantry in combat. ${ }^{4}$ The two best proxy measures that we use for "mission accomplishment" $-\mathrm{km}$ advanced and the mission success index -tend to be higher for the armored divisions than for infantry. Also of interest (in results not shown) is that task difficulty appears to have been higher for armored divisions as well. Although the number of troops in the opposing division was similar between pre-reorganization armor and infantry and somewhat lower for postreorganization armor, the number of tanks in the opposing division was considerably higher for armor in both cases. U.S. KIA is slightly higher for armor than for infantry, which could be attributable to higher task difficulty or usage intensity for armor. Despite the decrease in the armored division's troops and tanks, we observe a slight increase in $\mathrm{km}$ of progress and little effect on U.S. KIA. We see a negative effect of the armored reorganization on the index of mission success in panel $\mathrm{F}$, however, suggesting that mission effectiveness may have declined in a way that is not captured by geographical progress. For the infantry reorganization we observe slight increases in the mission success measure and in U.S. KIA.

Figure 2 illustrates the effects of the 1943-1944 reorganizations on usage in combat, geographical progress, and U.S. KIA in our second data set, the division by day panel. Panel A

\footnotetext{
${ }^{4}$ Regression results that duplicate the information in Figures 1 and 2 appear in the Appendix.
} 
shows the average number of Axis divisions in the same $0.25 \times 0.25$-coordinate (about 15 by 15 mile) cell as the division, and panel B shows the fraction of division days with five or more U.S. KIA. Airborne divisions had relatively high rates of exposure to Axis divisions, and infantry divisions had high numbers of days with five or more U.S. KIA. According to both definitions of days of combat, the armored and airborne reorganizations came with decreases in combat days for the two division types, and the infantry reorganization came with an increase in combat days for the infantry division type. The changes in combat days are reflected in the outcome measures, $\mathrm{km}$ of progress and U.S. KIA, for the full sample in panels C and D. The armored reorganization is associated with a slight increase in progress and a large decrease in fatalities for the armored division type, a result that is consistent with a decline in days of combat or the difficulty of tasks for which the armored division was used. A similar and more pronounced pattern can be seen for the reorganization of the airborne division, a result consistent with a decline in combat days or task difficulty for the airborne division type as well. The opposite pattern can be seen for the infantry reorganization, which shows a decline in progress and an increase in KIA, a finding that is consistent with an increase in combat days or task difficulty for infantry.

Panels E and F show the same outcome variables as in panels C and D; however, the sample is restricted to days in which the U.S. division was in the same geographic cell as one or more Axis divisions. For the division days with nearby Axis units in panels $\mathrm{E}$ and $\mathrm{F}$, progress is similar for armored and airborne and is slightly lower for infantry divisions. Also, for division days with nearby Axis units, the results show U.S. KIA is highest for airborne units, followed by infantry and armored units. The findings are consistent with armor having the highest combat effectiveness, followed by infantry, and finally by airborne; however, the results are also consistent with task difficulty being the lowest for armor and the highest for airborne. 
Notably, we see little effect of the decrease in armored division resources on progress or KIA. Although this could indicate that the change in troop and tank levels had no effect on usefulness in combat, it is also consistent with simultaneous declines in the armored division's usefulness in combat and the difficulty of tasks assigned to it. We see little effect of the infantry reorganization on progress or KIA during days of combat, which is unsurprising, given that the reorganization had little effect on the infantry division's resources. For the airborne division the 1943-1944 reorganization is associated with a slight decline in progress and a large decline in KIA. This is consistent with a decline in usage intensity of the airborne division and either an increase in combat effectiveness or a decrease in task difficulty.

\section{Model}

We now present the conceptual framework to guide us in investigating observed differences among division types in costs, success, and fatalities and the implied government's valuation of soldiers' lives. The cost function model used here is adapted from Rohlfs (2006a). Consider a country (or government) waging a war with $M$ total missions or campaigns. For each mission $m$, the government observes a vector $\mathbf{x}_{\mathbf{m}}^{\mathbf{g}}$ of pre-determined correlates of task difficulty and selects one of $S$ unit organizational structures $s_{m}$ and a usage intensity level $i_{m}$. For simplicity let the production functions for mission success $Y_{m}$ and own fatalities $F_{m}$ be the linear functions

(1) $Y_{m}=\alpha_{s_{m}}^{Y}+\alpha_{i}^{Y} * i_{m}+\mathbf{x}_{\mathbf{m}}^{\mathbf{g}} \boldsymbol{\beta}^{\mathbf{Y}}+\varepsilon_{m}^{Y}$, and

(2) $F_{m}=\alpha_{s_{m}}^{F}+\alpha_{i}^{F} * i_{m}+\mathbf{x}_{\mathbf{m}}^{\mathbf{g}} \boldsymbol{\beta}^{\mathbf{F}}+\varepsilon_{m}^{F}$, where $\alpha_{s_{m}}^{Y}$ and $\alpha_{s_{m}}^{F}$ are constant terms that are specific to organizational structure $s_{m}$, and $\varepsilon_{m}^{Y}$ and $\varepsilon_{m}^{F}$ are error terms representing unobserved determinants of difficulty. 
Organizational structure helps determine usage intensity, which the researcher does not observe. Let $i_{m}=\gamma_{s_{m}}+\mathbf{x}_{\mathbf{m}}^{\mathbf{g}} \boldsymbol{\beta}^{i}$ denote the usage intensity that the country would select for structure $s_{m}$ and vector $\mathbf{x}_{\mathbf{m}}^{\mathbf{g}}$, a function that we take as linear. Suppose that $\mathbf{x}_{\mathbf{m}}^{\mathbf{g}}$ can be partitioned into vectors $\mathbf{x}_{\mathbf{m}}^{\mathbf{o}}$ and $\mathbf{x}_{\mathbf{m}}^{\mathbf{u}}$, where the researcher observes $\mathbf{x}_{\mathbf{m}}^{\mathbf{o}}$. Substituting, we obtain

(1') $Y_{m}=\alpha_{s_{m}}^{* Y}+\mathbf{x}_{\mathbf{m}}^{\mathbf{o}} \boldsymbol{\beta}^{* \mathbf{o Y}}+\varepsilon_{m}^{* Y}$, and

(2') $F_{m}=\alpha_{s_{m}}^{* F}+\mathbf{x}_{\mathbf{m}}^{\mathbf{o}} \boldsymbol{\beta}^{* \mathbf{o F}}+\varepsilon_{m}^{* F}$ where $\boldsymbol{\beta}^{A^{\prime}}=\left[\begin{array}{ll}\boldsymbol{\beta}^{\mathbf{o} A^{\prime}} & \boldsymbol{\beta}^{\mathbf{u} A^{\prime}}\end{array}\right]$ for each $A \in\{i, F, Y\}, \alpha_{s_{m}}^{* A}=\alpha_{s_{m}}^{A}+\alpha_{i}^{A} * \gamma_{s_{m}}, \boldsymbol{\beta}^{* \mathbf{o} A}=\boldsymbol{\beta}^{\mathbf{o} i}+\boldsymbol{\beta}^{\mathbf{o} A}$, and $\varepsilon_{m}^{* A}=\alpha_{i}^{A} * \mathbf{X}_{\mathbf{m}}^{\mathbf{u}} \boldsymbol{\beta}^{\mathbf{u} i}+\mathbf{x}_{\mathbf{m}}^{\mathbf{u}} \boldsymbol{\beta}^{\mathbf{u} A}+\varepsilon_{m}^{A}$ for $A \in\{F, Y\}$. The coefficients $\alpha_{s_{m}}^{* Y}$ and $\alpha_{s_{m}}^{* F}$ can be interpreted as the reduced-form effects of a change in organizational structure that include the direct effects of the physical inputs and the indirect effects of changing usage intensity. ${ }^{5}$

The government's/military's utility here increases with $Y_{m}$ and decreases with $F_{m}$ and dollar costs $C_{m}$. It is convenient in the current setting to consider expected costs given expected levels of mission success and fatalities:

(3) $E\left[C_{m} \mid \bar{Y}, \bar{F}, \mathbf{x}_{\mathbf{m}}^{\mathbf{g}}\right]=E\left[C_{m} \mid \mathbf{x}_{\mathbf{m}}^{\mathbf{g}}\right]$ such that $E\left[Y_{m} \mid \mathbf{x}_{\mathbf{m}}^{\mathbf{g}}\right] \geq \bar{Y}$ and $E\left[F_{m} \mid \mathbf{x}_{\mathbf{m}}^{\mathbf{g}}\right] \geq \bar{F}$. Let $\tilde{C}_{m}\left(\bar{Y}, \bar{F}, \mathbf{x}_{\mathbf{m}}^{\mathbf{g}}\right)$ denote the expected expenditure required to obtain expected threshold levels $\bar{Y}$ and $\bar{F}$ of success and own fatalities. The total cost equation is analogous to the cost function in a producer's problem that depends on prices and output. Although wages and capital prices do not vary across missions the vector $\mathbf{x}_{\mathbf{m}}^{\mathbf{g}}$ of correlates of task difficulty plays a similar role as prices. Mission success and fatalities can be viewed as two different products whose output levels enter into the government's objective function. Let $P_{m}$ and $V$ equal the marginal values to the

\footnotetext{
${ }^{5}$ Strictly speaking, because the two production functions are initially simplified to be linear the subsequent cost function will also be linear so that the two marginal costs are constants, and there is no unique dual outcome cost minimum. The consequence is that the levels of mission success and fatalities will be determined by their marginal values to the military decision maker. We explore possible non-linear cost functions empirically in Section V.
} 
government of a unit of expected success and a unit reduction in expected fatalities. $V$ is the parameter of our empirical interest and is assumed constant across missions. The first-order conditions of the military's optimization are $P_{m}=E\left[\frac{\partial \tilde{C}_{m}\left(\bar{Y}, \bar{F}, \mathbf{x}_{\mathbf{m}}^{\mathbf{g}}\right)}{\partial \bar{Y}}\right]$ and $V=-E\left[\frac{\partial \tilde{C}_{m}\left(\bar{Y}, \bar{F}, \mathbf{x}_{\mathbf{m}}^{\mathbf{g}}\right)}{\partial \bar{F}}\right]$. $\tilde{C}_{m}(., .,$.$) is linear here and is then$

(4) $\tilde{C}_{m}=P_{m} * E\left[Y_{m} \mid \mathbf{x}_{\mathbf{m}}^{\mathbf{g}}\right]-V * E\left[F_{m} \mid \mathbf{x}_{\mathbf{m}}^{\mathbf{g}}\right]+\mathbf{x}_{\mathbf{m}}^{\mathbf{g}} \boldsymbol{\beta}^{\tilde{C}}+\varepsilon_{m}^{\tilde{C}}$,

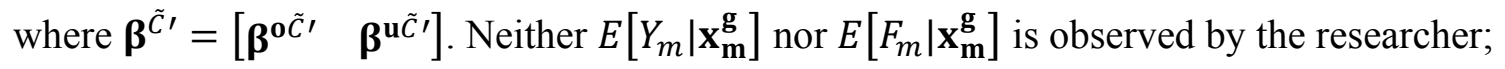
however, substituting Equations (1') and (2') into Equation (4), we obtain:

$$
\text { (4') } \tilde{C}_{m}=\bar{P} * Y_{m}-V * F_{m}+\mathbf{x}_{\mathbf{m}}^{\mathbf{o}} \boldsymbol{\beta}^{\mathbf{o} \tilde{C}}+\varepsilon_{m}^{* \tilde{C}},
$$

where $\bar{P}=\frac{1}{M} \sum_{m=1}^{M} P_{m}$ and $\varepsilon_{m}^{* \tilde{C}}=\left(P_{m}-\bar{P}\right) * Y_{m}+\mathbf{x}_{\mathbf{m}}^{\mathbf{u}} \boldsymbol{\beta}^{\mathbf{u} \tilde{C}}+\varepsilon_{m}^{\tilde{C}}-P_{m} * \varepsilon_{m}^{Y}+V * \varepsilon_{m}^{F}$. Note that we do not allow usage intensity $i_{m}$ to affect costs directly, which may lead to an upward bias in the estimation of $V$; however, the bias is probably not very large. ${ }^{6}$

Both $Y_{m}$ and $F_{m}$ are endogenous variables that are correlated with components of $\varepsilon_{m}^{* \tilde{C}}$, such as $P_{m}, \varepsilon_{m}^{Y}$, and $\varepsilon_{m}^{F}$. Hence, $V$ cannot be consistently estimated with an Ordinary Least Squares (OLS) regression of Equation (4'). ${ }^{7}$ Instead we use a Two-Stage Least Squares (2SLS) strategy in which $Y_{m}$ and $F_{m}$ are endogenous regressors whose values are predicted using equations (1') and (2') as first-stage regressions with indicators for the different organizational structures as excluded instruments.

\footnotetext{
${ }^{6}$ Higher levels of $i_{m}$ probably led to higher ammunition costs and capital losses. However, the cost data take into account differences across division types in ammunition usage and tank losses; hence, the cost differences will be reflected in the comparisons across division types. Depreciation of capital other than tanks was a relatively minor cost, making up only 3 per cent and 4 per cent of the costs of the 1942 standard infantry and armored divisions. Hence, the largest differences in equipment losses among division types are accounted for in our regressions. ${ }^{7}$ In particular, OLS estimates of the marginal costs of mission success and fatality reductions will be biased toward zero because shocks to the cost structure will lead to choosing fewer, shorter missions (less success) and fewer soldier safety measures (more fatalities) if the two outcomes are endogenous in (4').
} 
For the coefficients in Equation (4') to have a structural interpretation, it is essential that organizational structure $s_{m}$ is a choice variable that is endogenous to the model. Thus, the estimation strategy proposed here uses instruments that are not exogenous. Instead, we impose the weaker assumption of conditional exogeneity that, after controlling for $\mathbf{x}_{\mathbf{m}}^{\mathbf{o}}$, the organizational structure indicators are uncorrelated with unobserved determinants of task difficulty, and $P_{m}$, the importance of the mission. Hence, none of the division types can have been used more than others in tasks that were especially difficult in some unobservable way.

The main defense for imposing the conditional exogeneity assumption is that both the division by day panel and the engagement data include many control variables, among them detailed descriptors of enemy characteristics. Additionally, the sequential nature of the geographic targets limited the degree to which the Army could pick certain division types for certain tasks. Although Army doctrine recommended using each division type for a specific type of task, the main differences across tasks were the numbers and types of nearby ally and enemy units, factors that appear in $\mathbf{x}_{\mathbf{m}}^{\mathbf{o}}$. Some of our econometric specifications focus on within-division variation in organizational structure and control for U.S. division fixed effects, an approach that provides an even stronger way to control for battlefield strategy effects. Nevertheless, we note that the need for control variables and the possibility that the controls are incomplete represent limitations to our study.

One advantage of the 2SLS procedure here is that it combines the results from multiple margins of adjustment into a single measure of the rate at which the government made tradeoffs between dollars and U.S. fatalities. The procedure also has the unfortunate feature that it lacks transparency. To address improve transparency, we present the first-stage and reduced-form 
regressions in graphical form to illustrate the separate roles of each of the division types in the final estimates, and we present the 2SLS results separately for different sets of divisions. ${ }^{8}$

\section{A. Strategy and Endogenous Enemy Characteristics}

We include enemy units' characteristics in the set of controls, but the model does not allow enemy units' characteristics to respond to the U.S. unit's division type or usage intensity. For the division by day panel, the enemy unit assumption is probably reasonable. The division by day panel dataset's controls for enemy characteristics come from information on long-range movements. The measures of enemy locations probably responded to large-scale events such as the success of the overall war effort; however, they are too coarse to detect responses to a single U.S. unit's division type.

In the engagement data the controls for enemy characteristics include enemy troops, tanks, aerial sorties, and in some cases, Axis division fixed effects. At the division level, attacking units had the ability to choose their opponents; however, the U.S. was the attacker in 90 per cent of the combat days considered. The primary way that a defending force could respond is through retreat or withdrawal, actions that are treated as endogenous and are not included in the controls. So, for a given engagement it is not unreasonable to assume that the U.S. treated the German force's starting troop and tank levels as fixed quantities that did not

\footnotetext{
${ }^{8}$ The focus of our 2SLS approach is not the variation in the dependent variable but instead as a way to combine the various reduced-form coefficients into a summary measure of cost per life saved. In the just identified case where the sample includes only three division types and only two organizational structure indicators appear in the set of excluded instruments, the 2SLS procedure here is identical to measuring the effects of a weighted sum of the two policies (switching from type one to type two and partially switching from type two to type three), where the second policy is implemented in the exact proportion necessary to hold mission accomplishment constant. In our context, $V$ is the estimated effect of the weighted sum of policies on dollar costs divided by the effect on fatalities. (See Rohlfs (2006b) and the Appendix.)
} 
respond to the attacking unit's division type. ${ }^{9}$ German troops and tanks may have responded to American organizational structure for the one per cent of cases in which the German unit was the attacker, and German air sorties may have responded in the 17 per cent of cases in which there was German air support. Dropping observations with possible German responses to U.S. actions has little effect on the estimates, as does dropping the Axis inputs from the set of controls (results shown in the Appendix).

In some cases, a unit's actions in one engagement could generate benefits to other engagements. For instance, a U.S. unit's success could reduce the task difficulty for the next Allied unit facing the same enemy. In the current framework the government's value $P_{m}$ of the mission meters subsequent benefits to other U.S. units. Treating enemy characteristics as predetermined correlates of task difficulty in $\mathbf{x}_{\mathbf{m}}^{\mathbf{o}}$ helps to avoid double-counting of benefits in other engagements.

\section{B. Spillover Effects of Nearby Units}

Because multiple divisions usually traveled together as a corps, a given Allied division probably had spillover effects on the geographical progress of other nearby Allied divisions. The main specifications address spillover effects by including the numbers of nearby divisions of different types as control variables in the regressions. Hence, the benefits of the positive spillovers generated by a unit, while valued by the country, are not counted in the mission effectiveness of the unit. An alternative formulation that takes benefits into account is to model progress as a corps-by-day level phenomenon and to estimate Equation (4') at the higher level of

\footnotetext{
${ }^{9}$ Troop and tank levels in the engagement data measure the military strengths at the start of each engagement. If significant reinforcements arrived, the data treat this as two engagements, one before the reinforcements arrived and one after the reinforcements arrived (Dupuy, 1987, pg. 65).
} 
aggregation. Estimates using the corps level approach appear in the Appendix and, while less precise, yield generally similar results to results presented.

\section{$\underline{\text { C. Troop and Tank Regressions }}$}

One alternative formulation of the first-stage equations used in some of the specifications replaces the organizational structure indicators with continuous regressors measuring the numbers of troops and tanks of the U.S. unit together with their interaction. Implementing the troop-tank interaction approach involves the following substitutions into Equations (1') and (2'):

(5) $\alpha_{s_{m}}^{* A}=\alpha_{\text {Troops }}^{* A} *$ Troops $_{m}+\alpha_{\text {Tanks }}^{* A} *$ Tanks $_{m}+\alpha_{\text {TT }}^{* A} *$ Troops $_{m} *$ Tanks $_{m}$, for $A \in\{F, Y\}$. The approach summarized in (5) is in some formulations involving the engagement data, for which there are direct measures of U.S. troops and tanks, and it is the one used by Rohlfs (2006a, 2006b). The procedure has the disadvantages that many of the crosssectional differences in U.S. troops and tanks reflect differences in attachments or detachments (which the Army could change quickly depending on the needs of a given mission) or recent combat losses, increasing the likelihood that the differences are caused by unobserved determinants of mission difficulty. The equation (5) approach has the advantage, however, that it can be implemented with U.S. and Axis division fixed effects together with the full set of controls from the engagement data.

\section{Empirical Results}

We now present our main empirical findings. First, we show estimates from Equations (1') and (2') in such a way as to illustrate how the estimated cost per life saved varies across different policies and regression specifications. Due to the large number of pre- and post- 
reorganization division types and the complex interactions between combat effectiveness and usage intensity, the first-stage regressions of Equations (1') and (2') are cumbersome to present in tabular form. So, for simplicity the first-stage estimates appear graphically in Figure 3. The corresponding regression tables appear in the Appendix.

\section{A. Graphical Summaries}

In Figure 3 the variables that we treat as exogenous are division type (Armored, Infantry, or Airborne) and pre-post reorganization during 1943-1944. The combination of the two organization variables sorts the data into six or fewer distinct groups, depending upon data availability, which varies across the graphs shown. Each of the unit types had a certain cost, a certain rate of fatalities, and a certain level of mission accomplishment, which vary by model and which explain the existence of the eight different graphs.

The axes of the graphs in Figure 3 show only two dimensions, cost and fatalities, which we plot along the vertical and horizontal axes,. To illustrate the third dimension, mission success, in a way that is easily identifiable for readers, we plot the dashed isoquant curves shown. The curves are hand-drawn -- they are not the result of an estimation process -- and they are generated to be consistent with the ordering of the mission accomplishment levels achieved by the different unit types shown on the graph. Each of the resulting curves is the simplest, smoothest one that we could draw given the ordering of mission accomplishment levels observed in the data across the six or fewer points.

Within each of the eight panels in Figure 3 the estimated dollar cost of a 10.8-month deployment of that division type appears on the vertical axis. The cost estimates are the same as in Figure 1. We use the European Theater of Operations (ETO) costs in panels A through D and 
$\mathrm{G}$ and $\mathrm{H} .{ }^{10}$ The costs for the actual troop and tank levels appearing in panels $\mathrm{E}$ and $\mathrm{F}$ are also the same as in Figure 1. The estimated number of fatalities that the division would incur over that 10.8 months appears on the horizontal axis. The average levels of mission success as shown in the isoquants are predicted values by division type from Equation (1'), where the control variables are set equal to the averages over the sample being used. The isoquants show alternative combinations of dollar costs and U.S. fatalities that generate equivalent levels of mission effectiveness. Division types on the upper left of the graph were expensive in dollars but experienced few fatalities. Moving downward and to the right along an isoquant the dollar cost of the unit decreases. To maintain the same level of effectiveness, usage intensity increases, leading to higher numbers of fatalities. The slope of the curve is an estimate of the rate of tradeoff between expenditures and fatalities. In some cases, the curves could be steeper or flatter and still agree with the observed levels of success; however, the range of possible slopes is fairly narrow at many key points on the graphs.

Although the slopes of the isoquants in Figure 3 are not the result of a formal estimation process the placement of the different points in terms of cost, fatalities, and mission accomplishment is surprisingly restrictive in terms of what the isoquants might look like. In panels $\mathrm{A}, \mathrm{B}$, and $\mathrm{C}$, for instance, any isoquant that is consistent with the data must have a steep portion in the upper left part of the graph (to match the ordering of the two black points) and a flat portion in the lower right-hand part (to match the ordering of the two gray points).

To estimate fatalities we first computed predicted values from Equation (2'), where U.S. KIA is the dependent variable and the control variables are set to their sample averages. For the regressions using the division by day panel, total estimated KIA for a 10.8-month deployment

\footnotetext{
${ }^{10}$ The estimated cost for pre-reorganization infantry, which is missing in Figure 1, assumes that the percentage change in costs generated by the infantry reorganization was the same as in the engagement data. Additional information on the ETO costs presented in Figure 3 appears in the Appendix.
} 
comes from multiplying predicted KIA per combat day by the average division's number of combat days and dividing by the fraction of U.S. KIA that occurred on the combat days. To convert from KIA to fatalities, we divided the 10.8-month KIA totals by 0.84 , the fraction of U.S. deaths that were KIA. Hence, a division type's fatalities over the deployment are taken as proportional to KIA for that division type on an average combat day.

Panels A through D show results from the division by day longitudinal data; panels A and B use the sample of division days with nearby Axis divisions, and panels $\mathrm{C}$ and $\mathrm{D}$ use the sample of division days with five or more U.S. KIA. Panels E through $\mathrm{H}$ show results from the engagement data. In panels $\mathrm{G}$ and $\mathrm{H}$, the averages by division type use the coefficients from the troop and tank regressions, substituting in the average troop and tank numbers from the ETO data. The measure of mission success is km progress in panels $\mathrm{A}$ through $\mathrm{D}$ and the index of mission accomplishment in panels $\mathrm{E}$ through $\mathrm{H}$. Panels $\mathrm{A}, \mathrm{C}, \mathrm{E}$, and $\mathrm{G}$ use no control variables. Hence, for panels A, C, and E, the fatalities estimates are scaled versions of the KIA averages shown in Figures 1 and 2, and the mission effectiveness estimates used to generate the dashed lines are also taken from Figures 1 and 2. Panels B and D show conditional means estimated from regressions that control for date and continent, numbers of nearby Allied and Axis divisions, terrain, vegetation, weather, and combat experience; panels $\mathrm{F}$ and $\mathrm{H}$ control for date and continent, U.S. aerial sorties, enemy inputs, terrain, vegetation, weather, and human factors. The control variables just described are listed in the footnotes to Tables 1 and 2.

When the data are sufficiently informative in Figure 3 to determine the cost per life saved, as measured by the slope of the isoquant, it tends to be highest at the higher cost levels, with a generally steeper tradeoff than the efficient rate of $\$ 1$ million to $\$ 2$ million dollars per life. At the lower cost levels the cost per life saved tends to be lowest and flatter than the efficient rate 
just mentioned. In each of panels A, C, and E, dollar costs are highest for the armored divisions, and fatalities are highest for the airborne divisions. The isoquants are roughly convex in all three panels, with kinks around the middle expenditure levels in panels A and E and a backwardbending portion for the armored divisions in panel C. At the highest two cost levels in panel A, the average slope between the cost levels of the pre- and post-reorganization armored divisions on the highest isoquant is about $-\$ 3$ million per life. On the same isoquant in panel A the slope between the lowest cost levels of the pre- and post-reorganization airborne divisions is approximately $-\$ 0.5$ million per life. On the highest isoquant drawn on panel $\mathrm{C}$, the slope between the cost levels of the pre- and post-reorganization armored divisions is roughly $+\$ 2$ million per life. The curve flattens to about $-\$ 1$ million per life between the cost level of the post-reorganization armored and the fatality level of the infantry division. Although the slope is unclear at lower cost levels the curve is necessarily flatter than the roughly $-\$ 0.9$ million per life slope between the infantry divisions and the post-reorganization airborne division, which is on a lower isoquant. On the highest isoquant in panel $\mathrm{E}$, the average slope between the cost level of the pre-reorganization armored division and the fatality level of the post-reorganization airborne division is about $-\$ 0.7$ million per life. When the troop and tank regressions are used in panel G, many slopes are possible, and the data are fairly uninformative about the tradeoffs between expenditures and U.S. fatalities.

When we add controls to the regression for the sample with nearby Axis divisions in panel B, the slope steepens. On the second-highest isoquant in panel B the average slope between the cost levels of the pre- and post-reorganization armored divisions is about $-\$ 6$ million per life. On the highest isoquant in panel B the average slope between the fatality levels of the pre-reorganization armored and the post-reorganization airborne divisions is about $-\$ 1$ 
million per life. For the sample of division days with five or more U.S. KIA, adding controls in panel D generates isoquants that are not consistent with a government that values mission success. When controls are added to the engagement data in panels $\mathrm{F}$ and $\mathrm{H}$, we observe relatively flat slopes. In panels $\mathrm{F}$ and $\mathrm{H}$ the slopes of the isoquants between the fatality levels of the pre-reorganization armored and the pre-reorganization infantry divisions are not explicitly determined but are necessarily less than $-\$ 0.4$ million and $-\$ 0.6$ million per life, respectively.

\section{B. Regression Results}

Before presenting our cost function regression estimates it is important to emphasize the relative advantages of the two different data sets we use. The benefit of the engagement data is the quality of the measurements. Everything comes from detailed first-hand accounts, and we know how many people were on the battlefield on both sides, how much equipment they had, how many died, and we have a good metric for mission accomplishment. The downsides of the engagement-level data are selection bias and omitted variables bias - we only observe battles that were big enough to matter for U.S. divisions that were important in the war effort, and we don't have strong instruments for troop and tank use so we are left assuming that they are exogenous.

The benefits of the division-level data are exactly where the engagement-level data are lacking. We have instruments for troop and tank numbers (the reorganization policy), and we have a large and complete sample of all the engagements between U.S. and Axis forces. The disadvantages are the quality of the measurements. We have rough measures of U.S. division movements, which involve interpolations to estimate where each division was (and consequently distance moved, terrain, weather, and locations of enemy forces). Counting numbers of fatalities 
involves matching individual soldiers to dates of death, which are missing for some individuals and has some inconsistencies. However, the main measurement error problems in the divisionlevel data should be mitigated by the instrumental variables approach we use because the most important sources of measurement errors are in the endogenous variables. Finally, the value that the government placed on soldiers' lives is best estimated by looking at the full sample of fatalities in the division level data and not in the most important and high-profile engagements.

In addition to presenting in Tables 1 and 2 our cost function parameter estimates of the marginal costs of the two endogenous variables, mission success and soldiers' fatalities, we tabulate typical accompanying indicators of the models' instrument strengths and the degree with which the models' identifying instruments may be considered exogenous. ${ }^{11}$ Considering instrument strength, there is no unique critical value for the partial $F$ statistics for the excluded (identifying) instruments, rather a guiding principle that a higher $F$ is better (Angrist and Pischke 2009). However, as Greene (2012, p. 250) notes, the instrument strength check is neither a specification test nor is it a constructive test for model building, but instead a strategy that helps the researcher avoid possibly basing inference on unreliable statistics. Concerning whether the overidentifying restrictions are valid, we also note that lower Chi squares are better. However, formal overidentifying restrictions tests can be misleading because the empirical validity of the overidentifying restrictions is neither sufficient nor necessary for the validity of the moment conditions implied by the underlying model and in turn provide little or no information on the identification of parameters of interest (Deaton 2010, Parente and Santos Silva 2012).

We now turn to our 2SLS estimates of $\bar{P}$ and $V$ from Equation (4').

\footnotetext{
${ }^{11}$ We do not tabulate Hausman-Wu statistics of endogeneity of $Y$ and $F$ because our results uniformly reject exogeneity (equality of OLS and 2SLS estimates of the marginal costs in (4')). See footnote 14 for a numerical example of the difference.
} 
Division Data Results. Table 1 shows the 2SLS results for the division by day longitudinal data set. Within each of the two panels in the Table, a column shows results from a distinct 2SLS regression of Equation (4'), where the dependent variable is cost per combat day, the endogenous regressors are geographic progress and U.S. fatalities, and the excluded instruments are indicators for the different pre- and post-reorganization division types. ${ }^{12}$ To construct daily fatalities, we divide U.S. KIA by the product of the fraction of U.S. KIA that occurred on combat days and the fraction of U.S. fatalities that were KIA. The coefficient on progress can be interpreted as the U.S. government's valuation (marginal cost) of one km of progress in a typical combat day, and the coefficient on U.S. fatalities can be interpreted as negative one times the U.S. government's valuation (marginal cost) of one fatality reduction. ${ }^{13}$

In panel A of Table 1, the sample includes division days in which the U.S. division was in the same cell as one or more Axis divisions; in panel B, the sample includes division days in which U.S. KIA was five or more. The first three columns show results from the full sample of combat days, and columns (4) and (5) present results from the fixed effects samples. Column (1) shows results controlling for a time trend and continent fixed effects. Column (2) includes the full set of additional controls, and columns (3) and (4) add fixed effects for month x year, nearby Axis divisions, and $0.25 \times 0.25$-coordinate geographic cells. Relative to Figure 3, the regressions in columns (1) to (4) of Table 1 impose a constant slope on the isoquants and constant growth in mission effectiveness per dollar of expenditure from one isoquant to another. The regressions in column (5) control for U.S. division fixed effects, so that the indicators for armored and airborne

\footnotetext{
${ }^{12}$ As an indication of bias from ignoring endogeneity of $Y$ and $F$ in (4') their coefficients each shrink by 99 percent in absolute value if we use OLS to estimate the first regression in Table 1, for example.

${ }^{13}$ As noted earlier the basic estimating equation is linear in $F$ and $Y$ so that there are constant marginal costs. We explored the empirical validity of the linear cost function in (4') by including endogenous quadratics in progress and fatalities $\left(Y^{2}\right.$ and $\left.F^{2}\right)$ or by including an endogenous interaction term $(Y \bullet F)$ with no empirical success in finding nonconstant marginal costs.
} 
appear in the controls and the coefficients of interest are identified from variation generated by the reorganizations. The remaining columns of Table 1 apply varying restrictions to the sample so that different combinations of the instruments identify the coefficients of interest. In each case the regressions that controls for continent and a daily time trend are in the first column, while regressions with controls for month $\mathrm{x}$ year, Axis divisions, and cell fixed effects are in subsequent columns. We use standard errors clustered by U.S. division by year by month interaction, which are in parentheses (Cameron and Miller 2015). ${ }^{14}$

In columns (1) to (4) of Table 1 the coefficients on km progress are unstable and change signs across specifications in both panels. Hence, we do not find a consistent positive marginal cost of increasing mission success, possibly due to the combined imprecision of the first-stage progress measure and the linear specification. The U.S. fatality coefficients in columns (1), (2), (3), and (4) in panel A are $-1.436,-1.926,-0.476$, and -0.408 . All four fatality coefficients are more than twice the value of their standard errors, respectively. This is in contrast to the first four columns in panel B, where only the U.S. fatality coefficient in column (3) is more than 1.68 times larger than its standard error. In columns (1), (2), (3), and (4) of panel B the fatality coefficients are $-0.711,-4.673,-2.521$, and -3.197 . Thus, the marginal cost per life saved estimates in columns (1) to (4) in panels A and B range in value from $\$ 0.41$ million to $\$ 2.5$ million, with average and median estimates of $\$ 1.9$ million and $\$ 1.7$ million per life. The larger estimates are from regressions with negative coefficients on $\mathrm{km}$ progress, a result suggesting that the regressions with the higher cost per life saved do not adequately control for the mission effectiveness of the unit.

\footnotetext{
${ }^{14}$ The standard errors do not take into account any imprecision in the constructed dollar cost measures. Some serial correlation also probably exists between divisions and between days from different months. The smaller clusters used make the model estimable with the full set of controls and fixed effects. When we use fewer covariates, using fewer clusters in both datasets has little effect on the standard errors, as shown in the Appendix.
} 
When we add U.S. division fixed effects, as in the regressions in column (5), the coefficient on progress is positive in panel A and zero in panel $\mathrm{B}$, and the estimated costs per life saved are $\$ 0.3$ million and $\$ 0.4$ million. With the sample restrictions applied in columns (6) to (15), the coefficients on U.S. fatalities are negative in 18 , more than twice the value of their standard errors in four, and more than 1.68 times larger (but less than two times larger) than the value of their standard errors in three of the 20 specifications. The estimated cost per life saved tends to be larger in panel $\mathrm{B}$, with average and median values of \$2.8 million and \$1.3 million, than in panel $\mathrm{A}$, with average and median values of $\$ 1.3$ million and $\$ 1.2$ million. The coefficient on $\mathrm{km}$ progress tends to be positive in the sample with nearby Axis divisions in panel A and negative in the sample with five or more U.S. KIA in panel B; hence, the larger estimated cost per life saved in panel B is probably attributable to the regressions failing to adequately control for the policies' effects on mission accomplishment. When considering tradeoffs between armored and either of the other two division types the cost per life saved estimates in panel A range from $\$ 0.5$ million to $\$ 1.5$ million. The estimated cost per life saved is considerably lower, ranging from zero to $\$ 0.3$ million, when the sample is restricted to infantry and airborne divisions, and the coefficient on $\mathrm{km}$ progress is negative in three out of four specifications. In columns (12) to (15), we find comparable cost per life saved estimates pre- and postreorganization. The cost per life saved estimates are also generally smaller in the specifications that include the month by year, Axis division, and geographic cell fixed effects.

Engagement Data Results. Table 2 shows 2SLS estimates of Equation (4') from the engagement data. In panel A, mission success is $\mathrm{km}$ of progress along the attacker's axis of advance, and in panel B, mission success uses the subjective index. Within each panel, each column shows results from a different regression specification. In columns (1) through (5) the 
sample excludes the airborne observations, and the excluded instruments are three indicators for division type (armored, post-reorganization times armored, and post-reorganization times infantry). ${ }^{15}$ In columns (6) to (15), the excluded instruments are U.S. troops, U.S. tanks, and their interaction.

The coefficient on mission effectiveness is more consistently positive in Table 2 than in Table 1, probably due to the greater precision of the effectiveness measures in the engagement data. The specifications that use the success index in panel B have the most consistently positive and precisely estimated coefficients on mission effectiveness, a result that suggests that the specifications more effectively control for mission success than do the specifications in panel A. The coefficients on the success index is positive in 14 , more than twice their respective standard errors in six, and more than 1.68 times larger (but less than two times larger) than their standard errors in three of the specifications. The coefficient on km progress tends to be larger in Table 2 than in Table 1, because the engagement sample includes fewer combat days, and unlike U.S. fatalities the mission success measures are not scaled upward to count progress made on noncombat days. Among the specifications using division type as the excluded instruments in columns (1) to (5), the coefficient on U.S. fatalities is positive in the two specifications without additional controls beyond date and continent and is negative in the remaining eight specifications. Among the specifications with the additional controls, the cost per life saved estimates range from $\$ 0.1$ million to $\$ 1.9$ million. The specifications with all of the controls produce estimates of $\$ 0.4$ million to $\$ 0.6$ million per life saved, with both coefficients being more than twice the values of their respective standard errors.

\footnotetext{
${ }^{15}$ We exclude the 10 combat days of the $101^{\text {st }}$ Airborne Division in Bastogne in December 1944 from the sample due to high numbers of attached troops and tanks that made them unrepresentative of a typical airborne organization.
} 
When U.S. troops and tanks and their interaction are the instruments (columns (6) to (15)), the specifications are also sensitive to the inclusion of controls. When we include controls beyond date and continent, and when km progress is the measure of success in panel A, we obtain a small positive coefficient on U.S. fatalities in the sample with low tank-intensity and negative coefficients on U.S. fatalities in the full sample and in the sample with high-tank intensity. However, the specifications with negative coefficients on U.S. fatalities also produce negative coefficients for km progress, suggesting that the specifications in columns (6)-(15) of panel A also do not adequately control for mission effectiveness. In the corresponding specifications in panel B, we observe a consistently positive coefficient on mission success and estimated costs per life saved of $\$ 1.2$ million for the full sample, $-\$ 0.1$ million for the low tank intensity sample, and \$0.4 million for the high tank intensity sample (which includes some units around the tank-intensity level of the infantry division), which are results generally consistent with panel A of Table 1. Similar results appear for the fixed effects sample as for the full sample; however, the results become too imprecise to make inferences when we add fixed effects to the regressions in columns (14) and (15).

After taking into account placing value on soldiers' lives, our estimates from the mission effectiveness data suggest that the U.S. government initially appeared to value armored troops' lives more than those of infantry troops. Although the cost/value discrepancy between soldiers existed initially, the government seems to have regarded that decision as a mistake and reorganized the divisions in 1943. The reorganization largely corrected the discrepancy in the valuation of soldiers' lives between the armored and infantry units. An additional explanation for the difference in the two estimates is that soldiers in armored divisions had more human capital than soldiers in infantry divisions. Although we believe that some of the difference in the 
evaluation of troops lives is due to differences in training expenditures, which we measure, we interpret other differences as due to soldiers in armored divisions having more experience and higher quality experience than infantry soldiers.

\section{Conclusion}

Our study has examined tradeoffs that the U.S. government made among different types of military units so as to save soldiers' lives in WWII. Multiple data sources let us measure physical inputs, fatalities, geographical characteristics, and dollar expenditures of each unit, including new data compiled from archival sources on the experiences of all 67 U.S. divisions that fought on the Western Front. We examined the effects of substitution among three different types of units -- armored, infantry, and airborne divisions -- as well as the effects of mid-war reorganizations of each unit type. The conceptual framework presented guided us in understanding the interactions among the physical inputs of the unit, the intensity with which the unit was used, and the difficulty of tasks to which it was assigned. We also developed a procedure for estimating the marginal cost of reducing U.S. fatalities through an increase in tank intensity. If the U.S. government acted as though it were an economically rational decision maker who equated marginal costs and marginal benefits then the estimated marginal cost provides a measure of the implicit value that the government placed on reducing American military deaths.

Although variable across specifications, our empirical results indicate that, at moderate tank-intensity levels such as that of the infantry division, the cost per life saved from an increase in tank intensity for a deployment with average usage and task difficulty was roughly zero to \$0.5 million in 2009 dollars. The cost of life saving range falls below Costa and Kahn's (2004) 
$\$ 1$ million to $\$ 2$ million estimate of the private valuation of risk reductions among young men in the 1940s. At relatively high tank-intensity levels, such as that of the armored division, the cost per life saved from an increase in tank intensity was roughly $\$ 2$ million to $\$ 6$ million or more in 2009 dollars. Thus, our results suggest that relative to the private value of citizens at the time the U.S. government implicitly undervalued infantrymen's lives and slightly overvalued armored personnel's lives. Both the 1943 reorganization of the armored division, which greatly reduced costs and slightly increased fatalities, and the 1944 reorganization of the airborne division, which greatly reduced fatalities and increased costs slightly, increased economic efficiency.

\section{References}

Angrist, Joshua D. and Jörn-Steffen Pischke. 2009. Mostly Harmless Econometrics, An Empiricist's Companion. Princeton, NJ: Princeton University Press.

Axis History Fact book. 2009. "Military Organisations: Heer.” Available at: http://www.axishistory.com/index.php?id=30

Cameron, A. Colin and Douglas L. Miller. 2015. "A practitioner's guide to cluster-robust inference.” J. of Human Resources, 50(2), 317-72.

Costa, Dora and Matthew Kahn. 2004. "Changes in the value of life: 1940-1980." J. Risk \& Uncertainty, 29(2), 159-80.

Deaton, Angus. 2010. "Instruments, randomness, and learning about development." J. of Econ. Lit., 48(2), pp. 424-55.

Dupuy, Trevor N. 1987. Understanding War. New York: Paragon House Publishers.

The Dupuy Institute. 2005. “Appendix M: Representativeness of the DLEDB.” Unpublished Paper.

The Dupuy Institute. 2001. User Guides for the Dupuy Institute Databases. Annandale, VA. September.

Economist. 2005. “And Now, the War Forecast.” (September 17).

Evans, Martin Marix. 2002. Battles of World War II. Shrewsbury, England: Airlife Publishing, Ltd. 
Fuller, Colonel J.F.C. 1928. On Future Warfare. London: Sifton Praed \& Co., Ltd.

Gabel, Christopher R. 1985a. "Lorraine Campaign: An Overview, September-December 1944." Combat Studies Institute, United States Army Command and General Staff College.

Gabel, Christopher R. 1985b. "Seek, Strike, and Destroy: U.S. Army Tank Destroyer Doctrine in World War II." Leavenworth Papers No. 12, Combat Studies Institute, United States Army Command and General Staff College.

Gabel, Christopher R. 1986. "The $4^{\text {th }}$ Armored Division in the Encirclement of Nancy." Combat Studies Institute. United States Army Command and General Staff College.

Greene, William H. 2012. Econometric Analysis, Seventh Edition. Upper Saddle River, NJ: Prentice Hall.

Greenfield, Kent R., Robert R. Palmer and Bell I. Wiley. 1947. United States Army in World War II: The Army Ground Forces: The Organization of Ground Combat Troops. Washington, DC: United States Army Center of Military History.

Greenstone, Michael, Stephen P. Ryan, and Michael Yankovich. 2014. "The Value of a Statistical Life: Evidence from Military Retention Incentives and Occupation-Specific Mortality." MIT Working Paper.

Harrison, Mark. 1988. "Resource Mobilization for World War II: The U.S.A., U.K., U.S.S.R., and Germany, 1938-1945." Econ. Hist. Rev., New Series 41(2): 171-92.

Haskew, Michael E. 2009. “Order of Battle Western Allied Forces of WWII.” London: Amber Books, Ltd.

Kahn, Ely J. and McLemore, Henry. 1945. Fighting Divisions. Washington, DC: Zenger Publishing Co., Inc. (reprinted 1980).

Liddell Hart, Captain B.H. 1925. Paris or The Future of War. E.P. Dutton \& Company. New York.

Morrall III, John F. 2003. "Saving lives: A review of the record.” J. Risk \& Uncertainty 27(3), 221-37.

Morris County Library, 2009. "Historic Prices, Morris County NJ." Available at: http://www.gti.net/mocolib1/prices/.

Palmer, Robert R., Bell I. Wiley, and William R. Keast. 1959. United States Army in World War II: The Army Ground Forces: The Procurement and Training of Ground Combat Troops. United States Army Center of Military History. Washington, DC. Reprinted 1991. 
Parente, Paulo M.D.C and J.M.C. Santos Silva. 2012. "A cautionary note on tests of overidentifying restrictions." Econ. Letters 115(2), 314-17.

Rohlfs, Chris. 2006a. "The Government's Valuation of Life-Saving in War: A Cost Minimization Approach." Papers and Proceedings of the Amer. Econ. Assoc., 96(2): 39-44 (May).

Rohlfs, Chris. 2006b. "Three Essays Measuring Dollar-Fatality Tradeoffs and Other Human Costs of War." Ph.D. Dissertation, University of Chicago (June).

Rohlfs, Chris. 2012. "The economic cost of conscription and an upper bound on the value of a statistical life: Hedonic estimates from two margins of response to the Vietnam draft." $J$. Benefit- Cost Analysis 3(3), 1-37.

Rohlfs, Chris and Ryan Sullivan. 2013. "The Cost-Effectiveness of Armored Tactical Wheeled Vehicles for Overseas U.S. Army Operations.” Defence and Peace Economics, 24 (4), 293-316.

Rosen, Sherwin and Richard Thaler. 1975. "The Value of Saving a Life: Evidence from the Labor Market," in Household Production and Consumption, edited by Nestor E. Terleckyj, National Bureau of Economic Research. New York.

Rottman, Gordon L. 2006. U.S. Airborne Units in the Mediterranean Theater 1942-44. Oxford, United Kingdom: Osprey Press.

Stubbs, Mary Lee and Stanley Russell Connor. 1969. Army Lineage Series: Armor-Cavalry Part I: Regular Army and Army Reserve. Washington, DC: United States Government Printing Office.

Smith, R. Elberton. 1959. United States Army in World War II: The War Department: The Army and Economic Mobilization. United States Army Center of Military History. Washington, DC.

Stanton, Shelby. 1984. Order of Battle: U.S. Army, World War II. New York: Presido Press.

Steadman, Lieutenant Colonel Kenneth M. 1982. "The Evolution of the Tank in the US Army, 1919-1940.” Combat Studies Institute Report No. 1. Combat Studies Institute. United States Army Command and General Staff College. Fort Leavenworth, KS.

United States. Army Service Forces. 1942. "Army Supply Program: Section 1: Equipment, Ground.” Statistical Unit, April 6, 1942 (Box 704). Record Group 160, Entry 94. National Archives II Building, College Park, MD.

United States. Congress. 1932. Representative Collins speaking on War Department Appropriation Bill and resulting curtailment of Army activities. Congressional Record. $72^{\text {nd }}$ Congress, $1^{\text {st }}$ session, 1932, 75(9), daily ed. (May 10). 
Viscusi, W. Kip. 1993. "The Value of Risks to Life and Health.” J. Econ. Lit., 31 (December): 1912-46.

Viscusi, W. Kip. 1996. "Economic Foundations of the Current Regulatory Reform Efforts." J. Econ. Perspect. 10 (Autumn): 119-34.

Watson, Mark Skinner. 1950. United States Army in World War II: The War Department: Chief of Staff: Prewar Plans and Preparations. United States Army Center of Military History. Washington, DC. Reprinted 1991.

Wilson, John B. 1998. Maneuver and Firepower: The Evolution of Divisions and Separate Brigades. United States Center of Military History. Washington, DC.

Zaloga, Steven J. 2007. U.S. Airborne Divisions in the ETO 1944-45. Oxford, United Kingdom: Osprey Press 
Figure 1: U.S. Troops, Tanks, Estimated Cost, and Combat Outcomes by Division Type (Engagement Data)

Panel A: Actual U.S. Troops

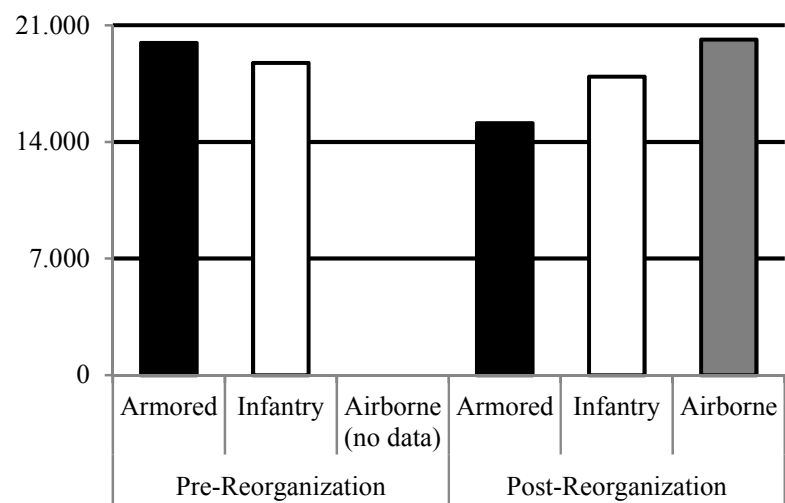

Panel C: Estimated Cost for Actual Division

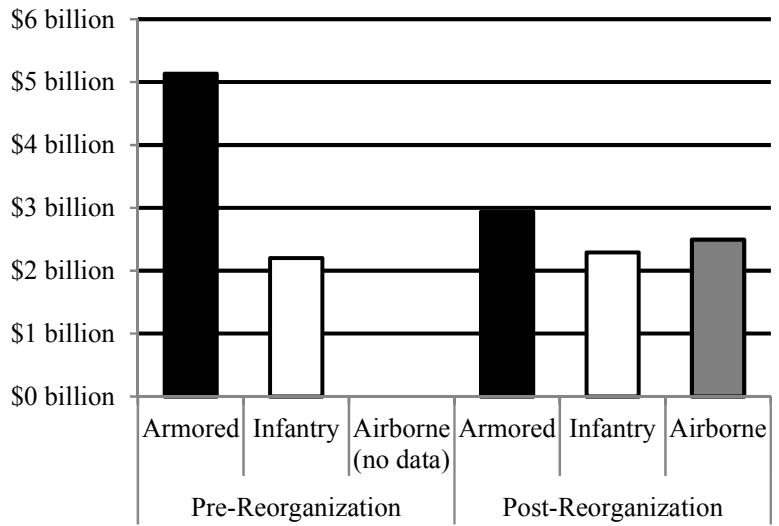

Panel E: U.S. KIA

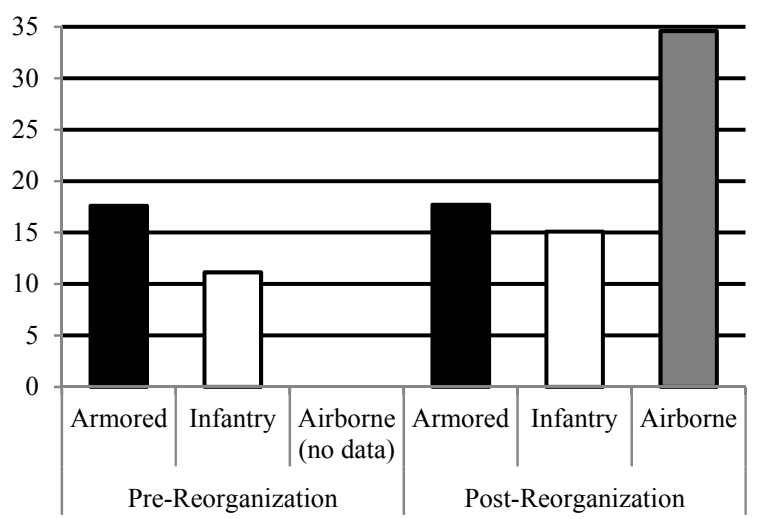

Panel B: Actual U.S. Tanks

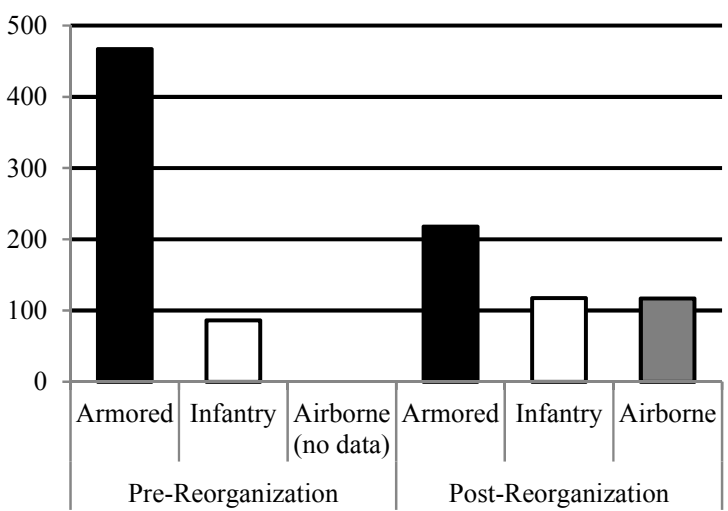

Panel D: Km Advanced

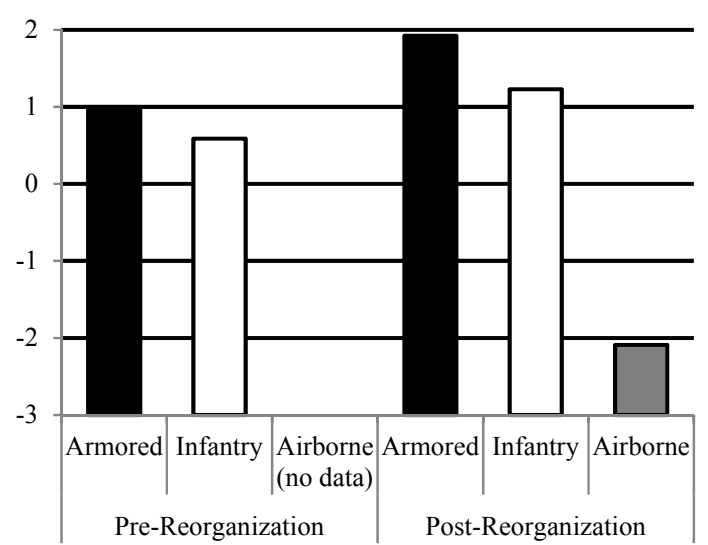

Panel F: U.S. Mission Success

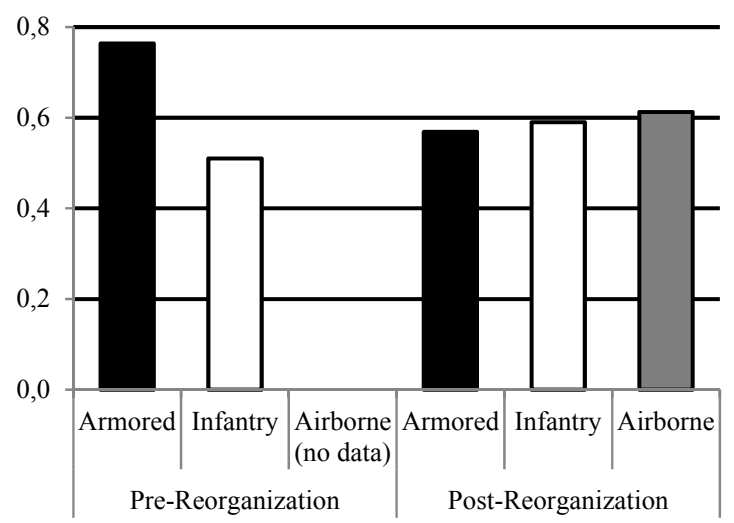

Notes to Figure 1: Actual troops and tanks are taken from primary sources such as morning roll call counts. Costs measured as $\$ 92,400$ per troop, $\$ 5.84$ million per tank, and an additional $\$ 1.63$ million per tank used in an armored division due to armored divisions' higher rates of tank losses. Estimated costs are in 2009 U.S. dollars. Mission success is measured as a zero to one index. Full sample is used and additional details are in the Appendix. 
Figure 2: Combat Outcomes and Usage in Combat by Division Type (Division by Day Panel)

Panel A: Number of Axis

Divisions in Cell

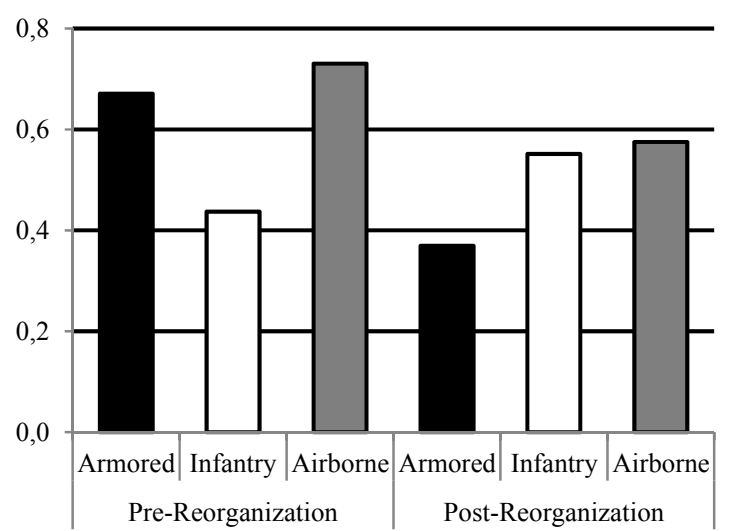

Panel C: Km of Progress per Day

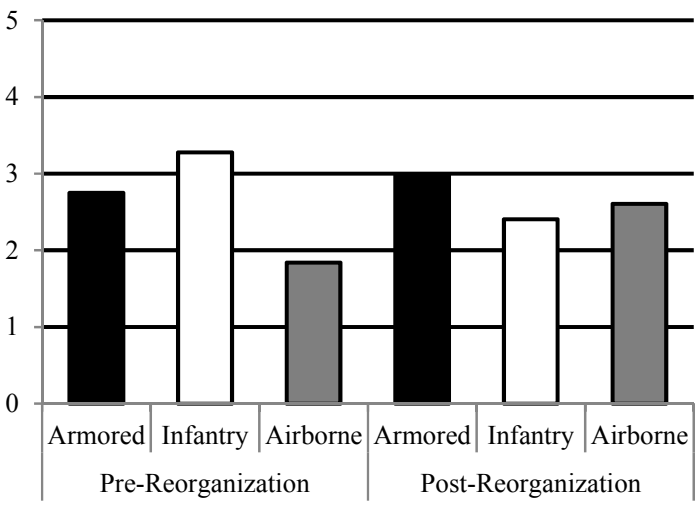

Panel E: Km per Day with Axis Divisions in Cell

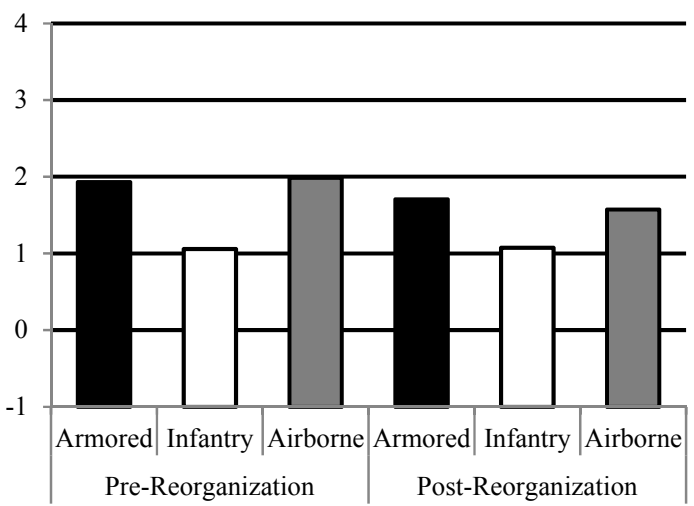

Panel B: Fraction of Days in Theater with U.S. KIA $\geq 5$

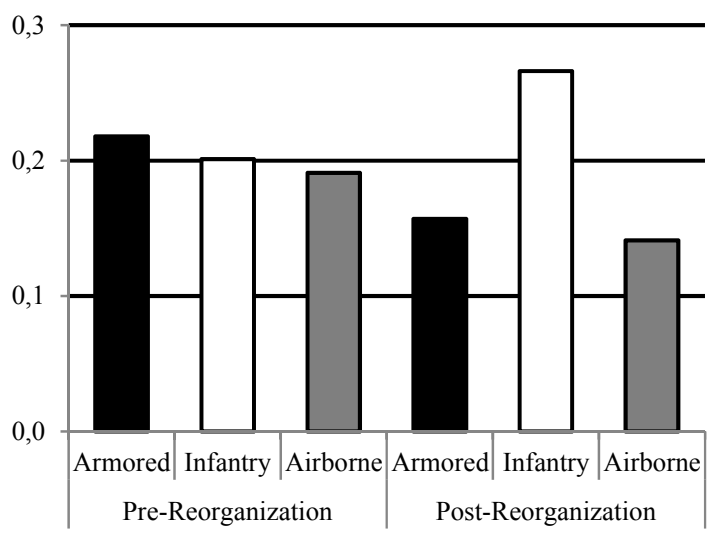

Panel D: U.S. KIA per Day

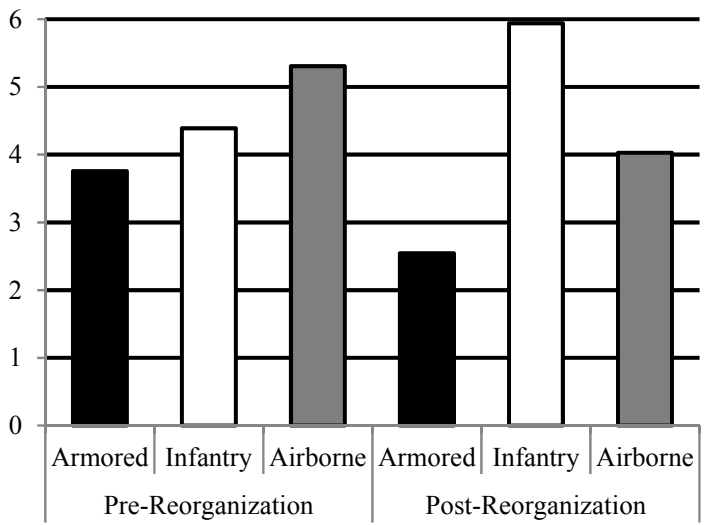

Panel F: U.S. KIA per Day with Axis Division in Cell

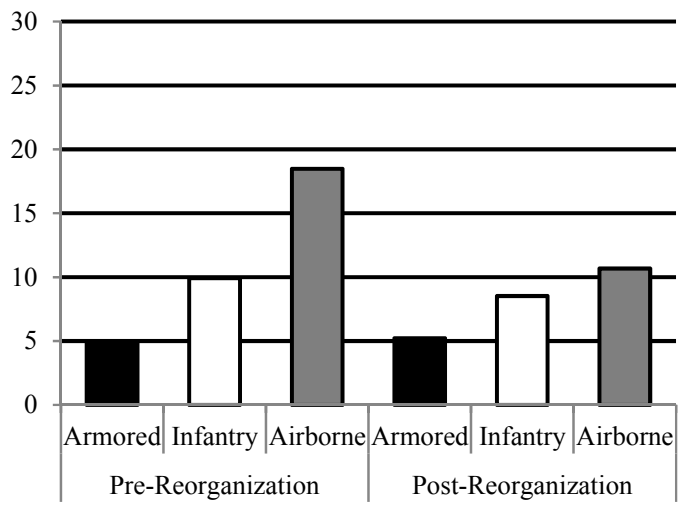

Notes to Figure 2: Data and variables are defined in the same way as in Table A1. Panels E and F show U.S. km of progress per day and U.S. KIA, respectively when the sample is restricted to observations in which one or more Axis divisions is in the same cell as the U.S. division. 
Figure 3: Estimated Costs, Fatalities, and Military Production Isoquants by Division Type

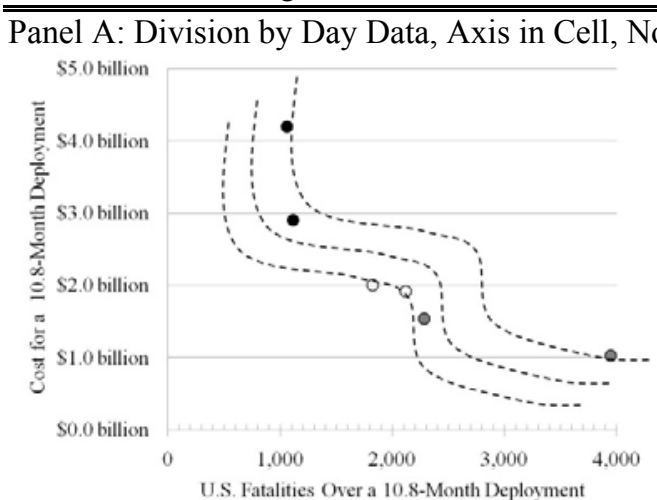

Panel C: Division by Day Data, U.S. KIA $\geq 5$, No Controls

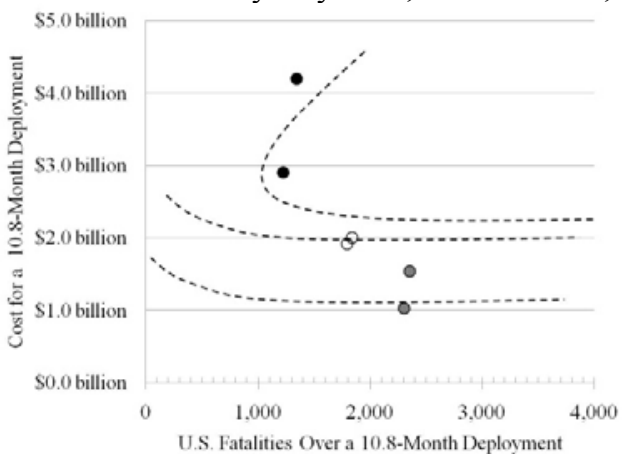

Panel E: Engagement Data by Division Type, No Controls

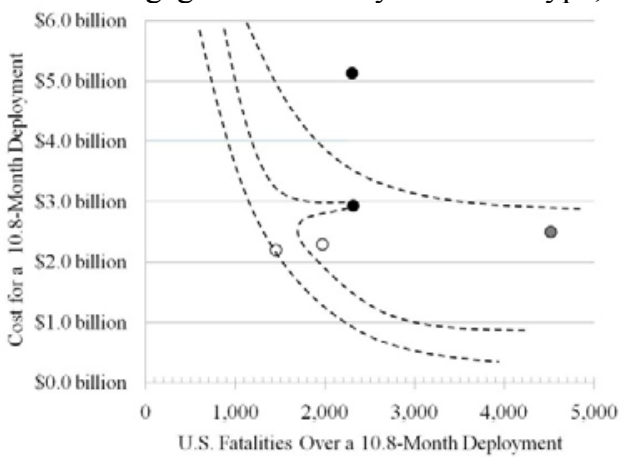

Panel G: Troop \& Tank Regressions, No Controls

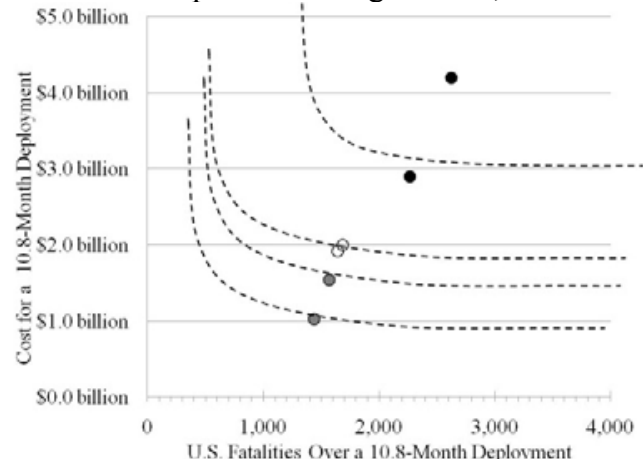

Panel B: Division by Day Data, Axis in Cell w/ Controls

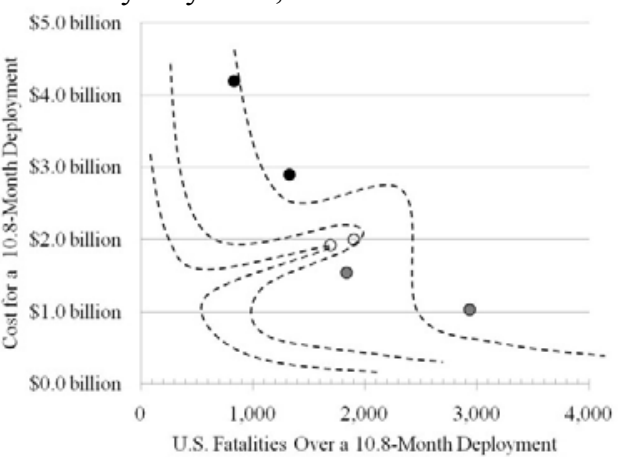

Panel D: Division by Day Data, U.S. KIA $\geq 5$ w/ Controls

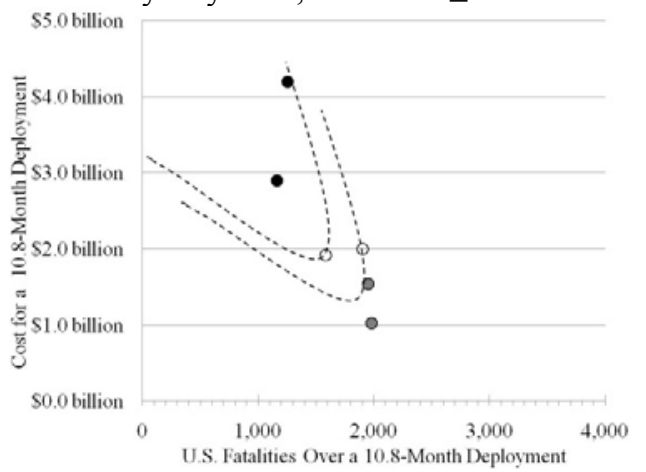

Panel F: Engagement Data by Division Type w/ Controls

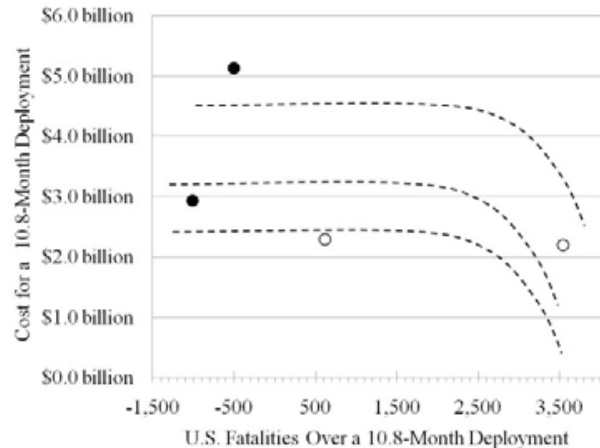

Panel H: Troop \& Tank Regressions w/ Controls

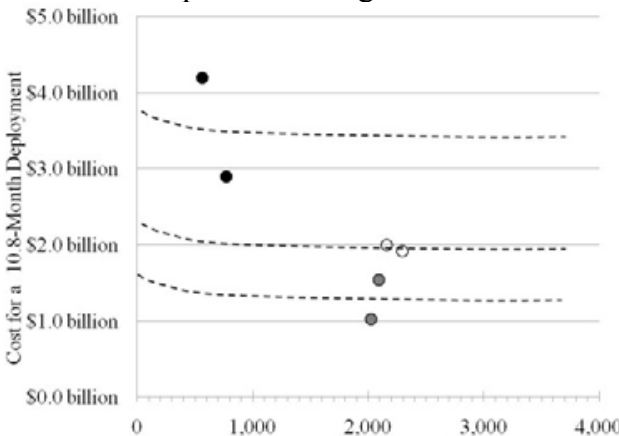

U.S. Fatalities Over a 10.8 -Month Deployment

Notes to Figure 3: In each panel, the points show estimated costs and fatalities for a given division type over a 10.8-month deployment, assuming average usage. The black dots correspond to armored divisions, the white dots correspond to infantry divisions, and the gray dots correspond to airborne divisions; both pre- and post-reorganization means are shown. The dashed curves show hand-drawn isoquants for military effectiveness that are consistent with the estimated levels of effectiveness of each division type. Effectiveness in panels A to D is $\mathrm{km}$ advanced while engaged in panels $\mathrm{E}$ to $\mathrm{H}$ with the mission success index. All w/controls specifications include the full set of controls. 
Table 1: 2SLS Estimates of the Cost Function for Military Operations, Division by Day Panel

Panel A: Division Days in Which Axis Divisions in Cell $\geq 1$

Excluded Instruments are Indicators for Armored, Airborne, Post-Reorganization*Infantry, Post-Reorganization*Armored, and Post-Reorganization*Airborne

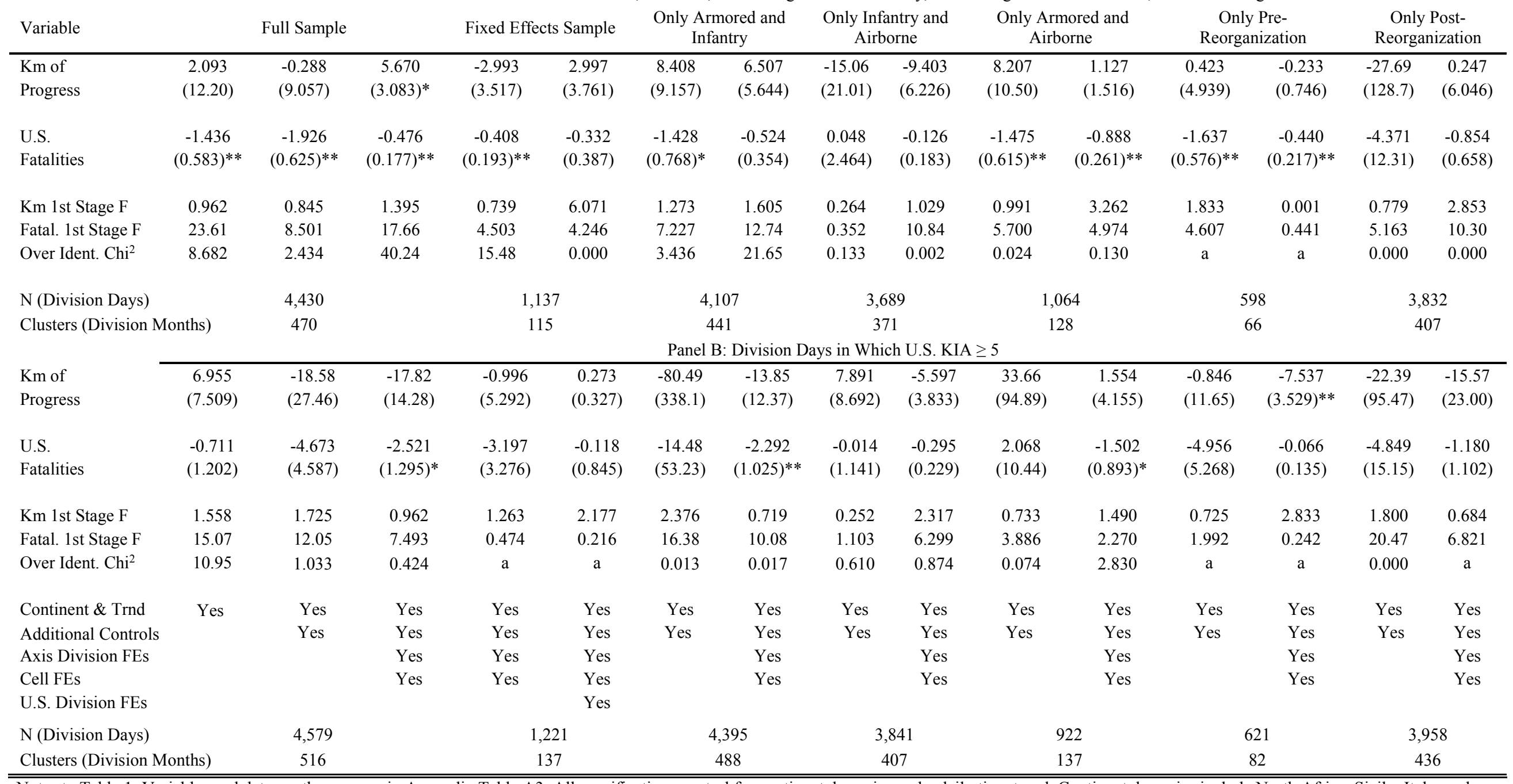

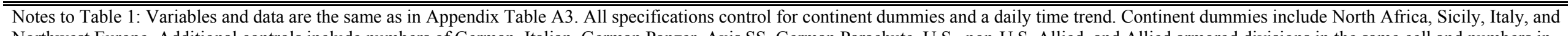

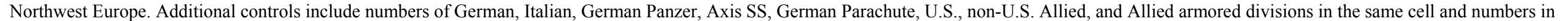

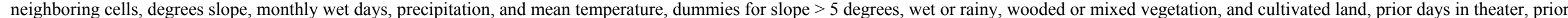

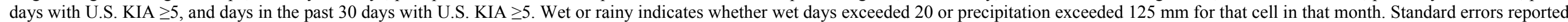
for all coefficients are clustered by division $x$ year $x$ month interaction. The letter "a" as reported for the Over Identification Chi denotes that the equation was exactly identified due to collinearity of the instruments. ** indicates the coefficient exceeds twice the value of its clustered standard error; * indicates the coefficient is more than 1.68 times larger but less than twice its clustered standard error. 
Table 2: 2SLS Estimates of the Cost Function for Military Operations, Engagement Data

$\begin{array}{lllllllll}(1) & (2) & (3) & (4) & (5) & (6) & \text { (7) } & \text { (8) } & \text { (9) }\end{array}$

Dependent Variable is Estimated Cost per Day in Millions of 2009 Dollars Panel A: Mission Effectiveness Measured as Km Progress

Excluded Instruments are Indicators for Armored, Post-

Reorganization*Infantry, and Post-Reorganization*Armored

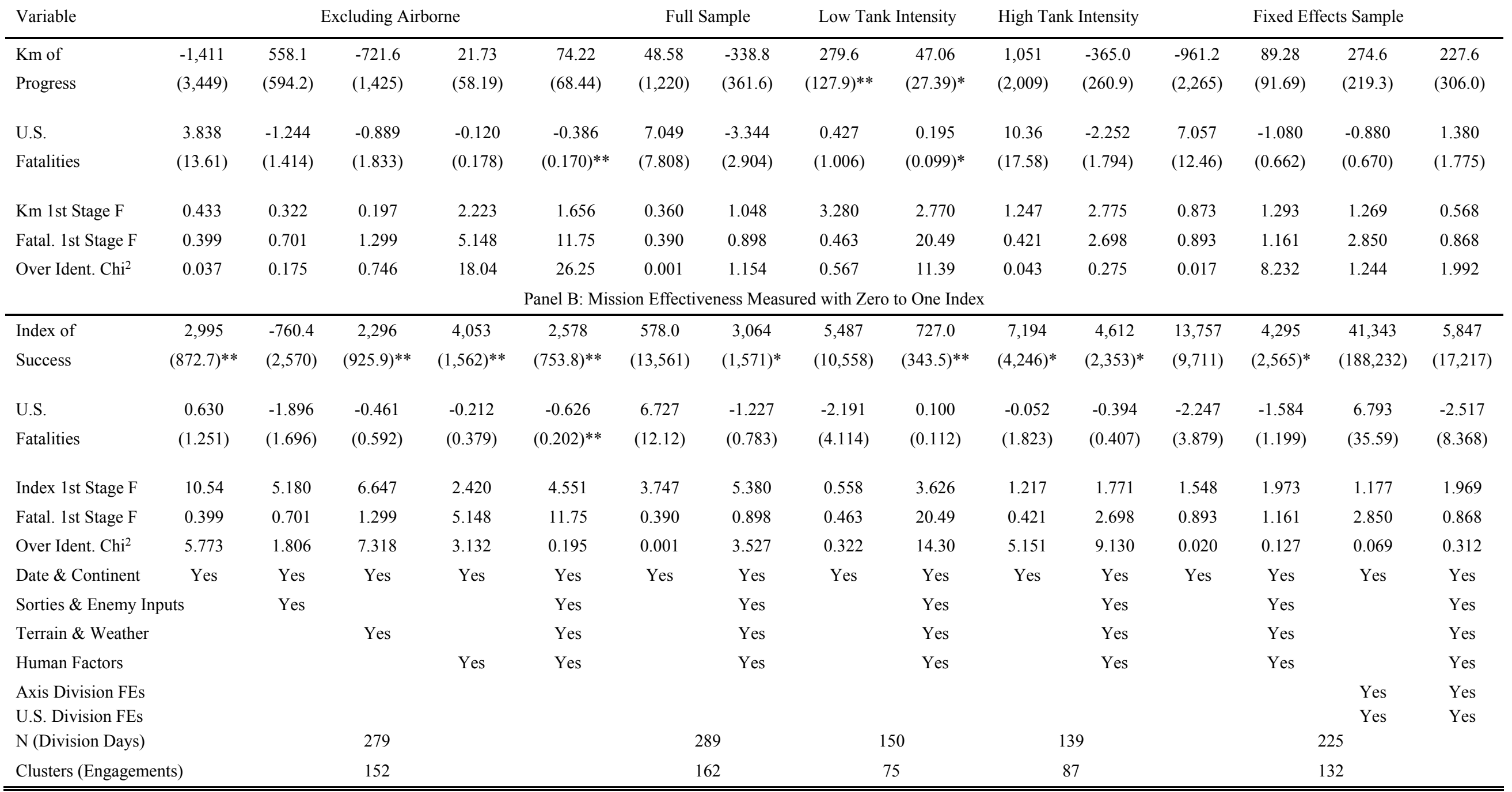

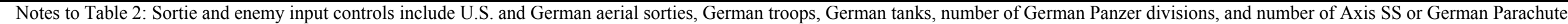

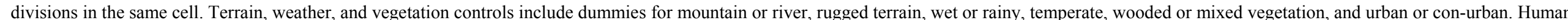

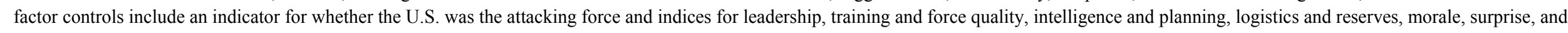

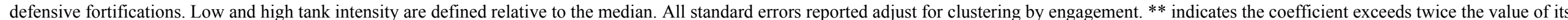
clustered standard error; and * indicates the coefficient is more than 1.68 times larger but than twice its clustered standard error. 
Appendix to "Reducing Risks in Wartime Through Capital-Labor Substitution: Evidence from World War II" by Chris Rohlfs, Ryan Sullivan, and Thomas J. Kniesner

\section{Background}

This appendix is a supplement to "Reducing Risks in Wartime Through Capital-Labor Substitution: Evidence from World War II." This document provides more detail than the text and data appendix of the paper on the effects of alternative specifications and the sources and calculations used to construct the datasets used in the study. An exhaustive compilation of the Excel spreadsheets, Stata programs, and Xeroxed archived records used in these calculations will be provided on request.

The remainder of this appendix proceeds as follows. Section II presents auxiliary results to those shown in Figure 3 and Tables 1 and 2 of the main paper. Section III describes the sources and calculations used to construct the division by day panel dataset. Section IV describes the engagement data in greater detail. Section V documents the sources and calculations for the construction of the cost estimates.

\section{Auxiliary Results}

This next section presents addition results on the effects of organizational structure that help to illustrate the mechanisms and calculations and explore the robustness of the findings. First, we present the numbers corresponding to the isoquant graphs in Figure 3 and use these to compute the cost per life saved using an alternative approach that does not involve 2SLS. Second, we show results from the first-stage regressions in tabular form. Third, we present alternative specifications to probe the sensitivity of the main results.

\section{A. Alternative Cost per Life Saved Calculations}

Table A3 presents in tabular form the totals by division type that are shown in Figure 3 of the main paper. Each column shows the totals for kilometers advanced (averaged across combat days in the sample being used), the subjective index of mission success (only for the engagement data), total U.S. deaths, and cost in billions of 2009 dollars for that division type. Rows 1 through 12 show estimates for the pre-reorganization division types, and rows 13 through 24 show estimates for the post-reorganization division types. The eight columns show estimates for the eight specifications shown in Figure 3. The relationships among these different numbers are discussed when Figure 3 is presented in the text; this table is included in the appendix so that the reader is able to see the exact values for each of the numbers in the graph.

In column (1) of Table A3, armored divisions advanced $1.929 \mathrm{~km}$ per combat day as compared to $1.058 \mathrm{~km}$ per combat day for infantry divisions. Hence, the results from column (1) of Table A3 suggest that replacing infantry with armored would increase the rate of advance by $(1.929-1.058)=0.871 \mathrm{~km}$ per combat day. In the sample column, we see that the postreorganization armored division advanced $1.706 \mathrm{~km}$ per combat day, making it $0.223 \mathrm{~km}$ per combat day less than the pre-reorganization armored division. As a first approximation, a policy that would reduce fatalities and hold the rate of advance constant would be to replace pre- 
reorganization infantry with pre-reorganization armor, thus increasing the rate of advance by $0.871 \mathrm{~km}$ per combat day, and then to implement the reorganization of the armored division $0.871 / 0.223=3.906$ times, bringing $\mathrm{km}$ advanced per combat day back down to the level of the pre-reorganization infantry division. To calculate the reduction in fatalities from this combination of policies, we first compute 2,120 -1,059=1,061 the difference in fatalities between pre-reorganization infantry and pre-reorganization armor, and we add to it 3.906 times the difference in fatalities between pre- and post-reorganization armor $(1,059-1,116)$, giving us $3.906^{*}(-57)=-223$. Hence, the total reduction in fatalities from this combination of policies would be $1,061-223=838$. The increase in dollar costs would be $\$ 4.20$ billion $-\$ 1.92$ billion plus 3.906 times ( $\$ 2.90$ billion -4.20 billion), giving an overall reduction in costs of $-\$ 2.80$ billion. The cost per life saved from this combination of policies is $-\$ 2.80$ billion divided by 838 , or roughly negative $\$ 3.3$ million. As mentioned in the main text, when only three division types are included in the sample (in this case, pre-reorganization infantry, pre-reorganization armor, and post-reorganization armor), then this calculation is mathematically identical to the 2SLS procedure used in the paper. A similar type of calculation and equivalent 2SLS procedure are shown in Rohlfs (2006b), where the two excluded instruments are U.S. troops and U.S. tanks and the policies involve increasing U.S. tanks and reducing U.S. troops. A variety of different policy combinations can be explored, each giving a different estimate of the cost per life saved.

Table A4 calculates the cost per life saved for six different effectiveness-neutral policy combinations for each of the specifications shown in Table A3. The estimate in the upper left is the same negative $\$ 3.3$ million calculated in the paragraph above. The degree to which the second policy is implemented varies across specifications depending on how much is necessary to keep mission accomplishment constant. Each combination shown here includes one reorganization and one replacement of a division type with another. The standard error is computed by running the two first stage regressions (with $\mathrm{km}$ of progress and U.S. fatalities as the dependent variables) as a system and applying the delta method (suest and nlcom in Stata). The figures below the costs per life saved show the reduction in fatalities generated by each policy combination. As the results from Table A4 show, the estimated cost per life saved varies considerably depending on the specification and the combination of policies being examined. Across all of the estimates shown, the average cost per life saved is $-\$ 1.2$ million and the median cost per life saved is $\$ 0.2$ million. It is straightforward to check that, if one considers replacing armored with airborne and then partially replacing airborne with infantry (a combination not shown here), the estimated cost per life saved is the same as the pre- or post-reorganization cost per life saved shown in Table 1 of the main paper.

\section{B. First-Stage Regressions}

Tables A5 through A7 present first-stage estimates of the effects of organizational structure on $\mathrm{km}$ of progress and U.S. fatalities. Table A5 presents estimates of the combat effects of the pre- and post-reorganization division type indicators using the division by day panel. The dependent variable is kilometers of progress in panel A and U.S. fatalities (the scaled version of U.S. KIA) in panel B. Within each panel, each column shows results from a separate OLS regression. The regressors of interest are an indicator for post-reorganization interacted with each of armored, infantry, and airborne and un-interacted indicators for armored and airborne; pre-reorganization infantry is the excluded division type. In columns (1) to (5), the 
sample is restricted to division days in which the U.S. division was in the same geographical cell as one or more Axis division. In columns (6) to (10), the sample is restricted to division days in which U.S. KIA was five or greater. The full samples are used in columns (1) to (3) and (6) to (8), and the fixed effects samples are used in columns (4) to (5) and (9) to (10). Columns (1) and (6) include a time trend and fixed continent effects, as in the first column of Table 1 of the main paper. Columns (2) and (7) add controls for the numbers of nearby Allied and Axis units of different types, terrain, vegetation, weather, and combat experience, as in the second column of Table 1 in the main paper. Columns (3) and (8) add fixed effects for month by year interactions, Axis divisions, and $0.25 \times 0.25$ coordinate geographical cells, as in the third column of Table 1 . The same set of controls is used in columns (4) and (9) as in column (3) and (8); however, the fixed effects samples are used. Columns (5) and (10) add U.S. division fixed effects. Standard errors clustered by division $\mathrm{x}$ month are shown in parentheses.

While they vary across specifications, the results from Table A5 are generally consistent with the patterns observed in Figure 3. Shifting from pre-reorganization infantry to prereorganization armor appears to increase combat effectiveness. The coefficient on armored in panel B shows a consistently negative effect of pre-reorganization armored relative to prereorganization infantry on U.S. KIA. The coefficient on armored in panel A varies across specifications and averages to about zero. Hence, usage intensity appears to have been lower for pre-reorganization armor relative to pre-reorganization infantry, so that the higher combat effectiveness led to similar geographical progress and lower fatalities. The results also suggest that shifting from pre-reorganization infantry to pre-reorganization airborne may have reduced combat effectiveness. In column (9), we observe large negative effects of airborne on progress and fatalities consistent with very low usage intensity. For the other specifications, the effect of airborne on progress switches signs across specifications and is on average slightly positive, and we observe a somewhat consistent and relatively large positive effect of airborne on U.S. KIA, a result consistent with a relatively ineffective force with high usage intensity.

As with Figure 3, the OLS results in Table A5 do not show a clear reduction in combat effectiveness of the armored division following the dramatic reduction in troops and tanks under the reorganization. While they vary somewhat across specifications, we find generally positive effects of the armored reorganization on progress and U.S. KIA, a result that is consistent with an increase in usage intensity. In the fixed effects specifications, however, we do observe a result consistent with a decline in the armored division's effectiveness: the armored reorganization appears to have considerably increased U.S. KIA and decreased or only slightly increased geographical progress. The OLS results for the infantry reorganization tend to show a slight positive effect on progress and a generally negative effect on U.S. KIA, a result consistent with an increase in combat effectiveness, despite the slight reduction in troops. The fixed effects estimates of the effects of the infantry reorganization are similar to the OLS in the division days with five or more U.S. KIA sample. In the division days with one or more Axis unit in the cell, however, the fixed effects estimates show significant declines in progress and U.S. KIA - a result consistent with a decline in usage intensity - and they do not suggest a large increase in combat effectiveness. The estimated effects of the airborne reorganization in column (9) indicates a large negative effect of the reorganization on combat effectiveness, with large declines in progress and large increases in fatalities. For the remaining nine specifications, however, the results are consistent with a positive effect of the reorganization on combat 
effectiveness. In the progress regressions, the coefficient changes signs across specifications and are on average slightly positive, and we observe a generally negative effect of the airborne reorganization on U.S. KIA.

Table A6 estimates the combat effects of the pre- and post-reorganization division types in the engagement data. Each column shows results from a different regression. The dependent variable is kilometers of progress in columns (1) and (2), the zero to one index of mission success in columns (3) and (4), the trichotomous win-lose-draw success measure in columns (5) and (6), U.S. KIA in columns (7) and (8), U.S. tank losses in columns (9) and (10), and German KIA in columns (11) and (12). All twelve regressions exclude the ten airborne observations. Consequently, the only coefficients of interest are an indicator for armored and the interactions of post-reorganization times indicators for armored and infantry. Additionally, data on tank losses are only available for 215 of the 279 combat days. The specifications in columns (1), (3), (5), (7), (9), and (11) control for a time trend and continent fixed effects; columns (2), (4), (6), (8), (10), and (12) add controls for U.S. aerial sorties, enemy inputs, terrain, weather, vegetation, and human factors. Sufficient data do not exist to estimate these regressions with U.S. or Axis division fixed effects. Standard errors clustered by engagement are shown in parentheses.

As with the division by day results, the estimates in Table A6 are generally consistent with the patterns shown in the graphical results. The estimated effects for armored divisions tend to indicate a positive effect of being a pre-reorganization armored division on combat effectiveness. With the exception of a negative effect on progress in the specification with no controls, we to observe a positive effect of armor on the various measures of mission success, and we observe a negative effect on U.S. KIA; the negative effect on U.S. KIA is large and significant in the specification with controls. We also observe a large and significant positive effect of armored on U.S. tank losses.

The results on the effect of the armored reorganization on the different mission success measures are mixed but generally negative. The estimated effects on U.S. KIA are also mixed, but in the specifications with controls, the effects of the reorganization on U.S. KIA and U.S. tank losses are both negative, and the effects on total U.S. tank losses are large and significant. Hence, usage intensity appears to have declined in response to the armored reorganization; however, the effects on combat effectiveness are unclear. The estimated effects of the infantry reorganization similarly suggest a decline in usage intensity. The coefficients for this reorganization are also mixed for the different outcome measures; however, for the specifications with controls, the effects on success and U.S. KIA both tend to be negative.

Next, Table A7 presents first-stage results from the troop and tank regressions in the engagement data. Rather than measure the effects of division type and the reorganizations, the regressors of interest in Table A7 are U.S. Troops/10,000, U.S. Tanks/100, and the interaction of these two. Hence, these specifications suppose that the effects of division type reflect a more general input-output relationship. The dependent variable is kilometers of progress in panel A, the index of mission accomplishment in panel B, and U.S. KIA in panel C. Within each panel, each column shows results from a different OLS regression. Columns (1) and (2) use the full sample of 289 division days, and columns (3) to (6) use the fixed effects sample. The regressions in columns (1) and (3) control for a time trend and continent fixed effects. Columns 
(2) and (5) add controls for enemy inputs, terrain, weather, vegetation, and human factors. Column (4) includes a time trend, continent fixed effects, and U.S. and Axis division fixed effects, and Column (5) includes the full set of controls plus U.S. and Axis division fixed effects.

The effects of troops and tanks vary considerably by outcome variable. In panel A, we observe mixed to negative effects of U.S. troops, positive effects of U.S. tanks, and a generally negative troop-tank interaction effect on geographical progress. In panel B, we observe a positive and sometimes large and significant effect of troops, a mixed but generally positive and sometimes significant effect of tanks, and a mixed but generally negative and sometimes significant troop-tank interaction effect on the index of mission success. In panel C, we observe a generally positive and sometimes large effect of troops on U.S. KIA, mixed results for tanks, and a generally negative troop-tank interaction term. Hence, U.S. troops appear to contribute substantially to mission accomplishment in a subjective sense; however, their contribution is not through geographical progress, and it is associated with higher casualties. Tanks appear to increase geographical progress and success but not casualties. Averaging across the specifications, the results suggest that one tank contributes about as much to mission accomplishment as do 34 troops.

\section{Sensitivity Analysis}

The remainder of this section presents alternative specifications to probe the robustness of the results. Figure A 1 and Table A8 show results in which the division by day panel are collapsed to the corps by day level. U.S. divisions' corps affiliations were obtained from Stanton (1984) and supplemented with information from Haskew (2009) on the corps affiliations of nonU.S. allied forces. Locations are then averaged across all divisions in the corps that day, and corps-level progress is estimated based on the location of the average U.S. division in the corps. U.S. fatalities are added up across all U.S. divisions in the corps, and the nearby enemy, terrain, vegetation, weather, and experience variables are averaged across the U.S. divisions in the corps. The division type indicators are also summed across divisions in the corps, so that each instrument measures the number of U.S. divisions of that type in the corps that day. The nearby unit controls are replaced with measures of the numbers of nondivisional units and non-U.S. Allied divisions in the corps. The total number of divisions in the corps is added as a control variable, so that the instruments influence substitution from one division to another and not the adding and subtracting of divisions.

Figure A1 shows the same isoquant graphs as are presented in Figure 3, but for the corps by day specifications. Only the Axis divisions in cell definition of combat days is used, because having five or more U.S. KIA is difficult to interpret in the corps setting when engagement with the enemy might vary across divisions in the corps. In each panel, costs on the vertical axis are the same as in Figure 3. Each division's contribution to U.S. fatalities is measured by regressing U.S. fatalities on pre-reorganization times armored, pre-reorganization times infantry, etc. The coefficients on the division type variables are plotted along the horizontal axis. Similar regressions are run with $\mathrm{km}$ progress on the left-hand side to determine the values for the mission effectiveness isoquants. Panel A shows results in which no controls are included in the regressions, and panel $\mathrm{B}$ shows results in which the full set of controls is included. 
The armored and infantry divisions and the post-reorganization airborne division are generally appear in the same places on the graphs in Figure A1 as in Figure 3. The one noticeable difference between the two figures is that the pre-reorganization airborne division has considerably lower fatalities. One primary explanation for the difference in pre-reorganization airborne is that, due to their small numbers of troops and consequent low combat effectiveness, the $13^{\text {th }}$ and $17^{\text {th }}$ Airborne Divisions were used at low intensity relative to other units in their corps. The general shape from Figure 3 is repeated in panel A of Figure A1, with a steep portion at the higher cost levels and a flatter portion at higher fatality levels, but with kinks in the middle ranges. The differences are somewhat less pronounced, however. Moving from the cost level of the pre-reorganized to that of the post-reorganized armored division on the middle isoquant, the slope is $-\$ 1.4$ million per life saved. At the lower cost levels, moving from the cost level of the post-reorganized infantry to that of the post-reorganized airborne the slope of the isoquant is $\$ 0.6$ million per life saved. When controls are added to the regressions in panel B, we observe a backward-bending portion to the curves, and the slopes of the isoquants are less clear than in panel A.

Table A8 shows the corps-by-day counterparts to the 2SLS regressions in Table 1. Due to the nature of corps organization, it is not straightforward using these data to restrict the sample to specific division types. As in Figure A1, only the nearby Axis forces definition of combat days is used. Columns (1) to (3) are the same as in columns (1) to (3) of panel A in Table 1. Column (4) adds corps fixed effects. Column (5) uses the fixed effects sample in which the sample is restricted to corps that at one time contained a division that was reorganized in the theater. Column (6) adds division fixed effects. Columns (7) to (11) show the same specifications in the just identified case in which the reorganizations are ignored and armored and airborne are the only excluded instruments. The division fixed effects specification is not estimable in this case because armored and airborne are perfectly collinear with the division fixed effects.

The coefficient on km progress in Table A8 tends to be larger than in Table 1 because the cost and value of moving multiple divisions are larger than for moving a single division. The estimated cost per life saved is smaller than in Table 1. When all division types are included in the sample with nearby Axis divisions in Table 1, the average and median cost per life saved estimates are $\$ 0.9$ million and $\$ 0.5$ million. In Table $A 8$, the average and median cost per life saved estimates are considerably smaller, and $\$ 0.2$ million and $\$ 0.1$ million.

Tables A9 and A10 explore the importance of autocorrelation in biasing the standard errors in Tables 1 and 2. In general, changing the form of clustering has little effect on the overall precision of the estimates. Table A9 shows estimates for the seven columns from Table 1 that do not include any of the fixed effects. Underneath each coefficient, the first number in parentheses is the benchmark standard error, which is constructed by clustering by division $\mathrm{x}$ year $\mathrm{x}$ month. The second number in parentheses is a standard error that corrects for clustering by corps $\mathrm{x}$ year $\mathrm{x}$ month, and the third number in parentheses shows a standard error that corrects for clustering by division. On average, the standard errors are roughly $15 \%$ larger when clustering by corps $\mathrm{x}$ year $\mathrm{x}$ month and roughly $15 \%$ smaller when clustering by division. Moving from division $\mathrm{x}$ year $\mathrm{x}$ month to corps $\mathrm{x}$ year $\mathrm{x}$ month clustering, only one of the 28 coefficients changes significance, moving from significant to marginally significant. Moving 
from division $\mathrm{x}$ year $\mathrm{x}$ month to division clustering, one coefficient goes from marginally significant to significant, and another goes from insignificant to significant.

Table A10 shows estimates from the eight columns from Table 2 that do not include fixed effects or the full set of controls. The first row in parentheses underneath each coefficient is the benchmark standard error that corrects for clustering by engagement, and the second row in parentheses is a standard error that adjusts for clustering by division. The standard errors that cluster by division tend to be roughly $10 \%$ larger, and when moving from clustering by engagement to clustering by division, one significant coefficient becomes marginally significant, and one marginally significant coefficient becomes insignificant.

Table A11 shows a handful of alternative specifications for the 2SLS regressions using the engagement data. The benchmark cases with the full sets of controls are shown in column (1) for the specification using division type as the excluded instruments and in column (8) for the specification using troops, tanks, and their interaction as the excluded instruments. Columns (1) and (2) include the full sample excluding the $101^{\text {st }}$ Airborne. Columns (8) and (9) include the full sample. Columns (3), (4), (10), and (11) remove observations in which the U.S. was the defending force. Columns (5), (6), (12), and (13) remove observations in which German aerial sorties were not zero. Columns (1), (3), (5), (7), (8), (10), (12), and (14) include the full set of controls. Columns (2), (4), (6), (9), (11), and (13) remove U.S. sorties and enemy inputs as controls.

The results from columns (1) to (6) and (8) to (13) of Table A11 indicate that the coefficients of interest are somewhat sensitive to how strategic actions are modeled. In ten of the twelve specifications estimated with and without controls for U.S. sorties and enemy inputs, removing those variables from the set of controls reduces the estimated cost per life saved. The magnitude of this effect is nontrivial; however, the general pattern in the data is the same whether or not the U.S. sorties and enemy input controls are included. Across all of these specifications, when all of the controls are included, we obtain average and median costs per life saved of $\$ 1.4$ million and $\$ 0.8$ million. When the U.S. sorties and enemy inputs are removed from the set of controls, we obtain average and median cost per life saved estimates of $\$ 1.6$ million and \$0.4 million. Restricting the sample to cases in which the U.S. was the attacking force or cases with no Axis air support generally increases the estimated cost per life saved; however, it decreases the estimated cost per life saved in the troop and tank regressions using the mission success index. These changes to the specification also have nontrivial effects on the estimates but do not qualitatively affect the pattern of results.

In columns (7) and (14), of Table A11 the cost of the division is assumed to be larger if it has medium tanks than if it has light tanks. The costs are assumed to be proportional to the purchase prices of the items. A light tank is assumed to be $84.9 \%$ and a medium tank is assumed to be $110.3 \%$ of the cost of a tank used in the benchmark calculations, so that the cost of a 1942 organic armored division is unchanged. Additionally, in column (14), light and heavy tanks are included as separate instruments and are separately interacted with troops. Both columns (7) and (14) drop the one observation in which the fraction medium versus light tanks is not known. 
In the regressions in column (7) in which only the cost variable is changed, we see hardily any effect of treating medium and light tanks separately. In the troop and tank regressions in column (14) in which the set of instruments changes as well, treating medium and light tanks separately generates lower but more precise estimates of the cost per life saved in the regressions using $\mathrm{km}$ advanced as the mission effectiveness variable, and it produces similar and slightly more precise estimates of the cost per life saved in the regressions using the index of success.

\section{Division by Day Panel}

This next section describes in greater detail than in the main text of the paper the data used to construct the division by day panel. The three types of data sources described here are the U.S. fatalities data, those measuring Allied and Axis unit locations, and the geographic characteristics.

\section{A. U.S. Fatalities Data}

U.S. military fatalities are measured from seven different data sources. These data sources are summarized briefly in Table A12 and are described in greater detail in the paragraphs below. The WWII casualties dataset that is used in the analysis was obtained by combining these sources to obtain non-missing values for a large number of observations and to compare values across the different sources to improve the accuracy of the data.

Reading Room Data (U.S. War Department, 1947). The primary source of fatalities information used in this study is a roster listing all 146,431 combat deaths to U.S. Army ground divisions in World War II, Army Chemical Warfare Service, and suicides and executions of U.S. Army troops. The rosters are meant to be complete, though some missing observations have been found from other sources. For each death, the data include name, serial number, divisional and battalion/regiment affiliation, rank, broad category of military occupation, and type of death (killed in action, died of wounds, or finding of death). For $45.1 \%$ of cases, depending on the division, battalion/regiment, and the first letter of the soldier's last name, the exact date of death was hand-entered onto the records near the time that they were printed. Some of the numbers were unreadable or cut off, but accurate dates were recoverable from these data for $40.9 \%$ of cases. Additionally, a few pages were missing from the original files. The dataset was Xeroxed from paper records at National Archives II in College Park, Maryland. With the help of financial assistance from the National Bureau of Economic Research and Syracuse University, these paper copies were scanned and sent as pdf files to Comat Technologies, Inc., in Bangalore, India, to have the data hand-entered. Every variable except name was entered. We then performed a first merge with the WWII serials file to identify individuals' names and sent the data back to India to have these names checked and have the correct ones filled in. For all variables except name, a second entry was typed in by me, and every inconsistency was double-checked and updated with the correct value. The data were also compared against the other fatality data sources used in this study and were checked by us and a research assistant at Syracuse University for many types of internal inconsistencies including names appearing out alphabetical order, unusual clusters of letters in names, and duplicate serial numbers. 
Airborne Division Deaths (U.S. Airborne in WWII, 2010). One secondary source of U.S. deaths that is used in this study include name, rank, division, battalion or regiment, company (in many cases), general location, date of death (in nearly all cases), type of death (in some cases), and cemetery for all 9,209 combat and non-combat deaths to airborne divisions, including deaths to attached units. These data do not include serial numbers; however, matches were generally possible with other data sources based on name, unit, rank, and date of death. These data were downloaded in electronic form from a website entitled "U.S. Airborne in WWII" in January, 2010.

WWII Honor List (U.S. War Department, 1946). These data include the name, rank, type of death, branch of service (Army including Army Air Forces, Navy, Marines, and Coast Guard), hometown, state, and (for Army) serial number for all 307,185 U.S. Army military personnel who died in World War II, including battle and non-battle dead and missing personnel for ground and air forces. The data do not include unit affiliations or date of death, but they constitute one particularly complete listing of the names and serial numbers of WWII casualties. These lists are provided as multiple pdf files on the NARA website. The American Battle Monuments Commission (ABMC) had an outside company hand-enter the data, and they provide the data along with data from the corresponding lists for the Navy, Marines, and Coast Guard personnel, on the National WWII Memorial website. The dataset is labeled on that site as "National Archives Records." A complete electronic copy of this dataset was obtained from ABMC through a Freedom of Information Act (FOIA) request submitted in January, 2009.

Machine Records Data (U.S. War Department, 1944). Another archival source of U.S. fatalities includes all 101,250 dead, missing, captured, and wounded personnel, battle and non-battle, for all military branches from 1941 through 1943. The data include name, serial number, home county, rank, broad category of military occupation, type of casualty, and date of casualty. Xeroxes of these files were purchased from Archives II, scanned, and sent as pdf files to Comat Technologies, Inc., in Bangalore, India, to have the data hand-entered. To save on time and expenditures, the name was not entered, and no second entry was made for any of the variables. However, the data have been merged with the other sources and checked for internal consistency to ensure the accuracy of the resulting casualties database. The rosters are organized by state and county in the hard copies, and some pages are missing from the originals. The last page in the Montana records include only casualty from Musselshell County, Montana; the remaining casualties from Musselshell County, Montana and casualties from counties that come alphabetically after Musselshell (Park County through Yellowstone National Park) are missing.

ABMC Cemetery Files (U.S. ABMC, 2005). These data include name, serial number, branch of service, divisional and battalion/regiment affiliation, rank, type of death, date of death, date of birth, age, home town, burial plot location, and awards won for 180,735 WWII battle and nonbattle deaths from any branch of service buried in American memorials and overseas military cemeteries. These data are not representative and do not include individuals who were not recovered or were buried in non-military cemeteries; however, they include an extensive set of variables for the observations that are included. These data are available as a searchable database on the ABMC website. A complete electronic copy of the data was purchased for $\$ 50$ from ABMC in September 2008. 
AGRS Remains not Recovered File (U.S. American Graves Registration Service, 1954). These data include name, serial number, rank, branch of service, and date of loss for all 79,021 dead or missing American military personnel whose remains had not been recovered as of 1954. A cleaned version of these data is available on multiple web pages on the website of the Defense Prisoner of War / Missing Personnel Office (DPMO); however, the cleaned version excludes many personnel whose remains were recovered after 1954. Consequently, an electronic copy of the original, uncleaned version of these data was obtained through a FOIA request sent to the Department of Defense FOIA Office on March 2009 and forwarded to DPMO.

WWII Serials Files (U.S. National Archives and Records Administration, 2002). These data include name, serial number, home state and county, enlistment location, date of enlistment, rank, branch of service, term of enlistment, country of birth, year of birth, race and citizenship, education, civilian occupation, marital status, and component of the army for 8,706,394 military personnel who enlisted between 1938 and 1946. Draftees are included in the sample, but officers are not. These data were purchased in electronic form from the Electronic and Special Media Records Division of the National Archives and Records Administration (NARA), who created the dataset from the Army's original computer punch cards.

Adjutant General Final Report (U.S. Army Adjutant General, 1953). This final report from includes tabulations and breakdowns of the battle casualties (including dead, wounded, captured, missing) and non-battle deaths of U.S. Army personnel from 1941 through 1946. The two-way tabulations include different types of casualties and deaths by division, by theater, and by month of occurrence. This dataset was used in earlier versions of this study to check totals and remains a valuable source to check totals and compare cross tabulations.

The Reading Room Data are treated as the main data source for fatalities. In many cases, the year was cut off from the data of death in the original file; in these cases, a likely year was estimated based on the dates of death of other members of that unit. Dates of death that occurred outside the dates that the division was at sea were recoded to missing. The airborne deaths were dropped and replaced with information from the U.S. Airborne in WWII website. These airborne deaths were merged with the Reading Room Data, the ABMC Cemetery Files, and the WWII Honor Lists to obtain independent confirmation of the observations. Non-combat deaths, deaths that were confirmed to have occurred in another unit, and deaths that could not be confirmed in another source were dropped. Date of death was first taken from the Reading Room Data, then the airborne data, then the imputed Reading Room Data, then the ABMC data, then the Machine Records data, and finally the Remains Not Recovered Data. The priority of the merge was determined based on the rates of agreement between the different sources. The vast majority of date observations were taken from the Reading Room, airborne, imputed reading room, and $\mathrm{ABMC}$ data, which all have $95 \%$ or more agreement among the non-missing observations.

\section{B. Unit Locations}

The information on unit locations that is used in this study comes from a variety of sources, mainly secondary, such as atlases of WWII, orders of battle, and memoirs. 
U.S. Unit Locations. For each American ground division, Stanton's (1984) U.S. Order of Battle in WWII contains a historical account of the cities visited on different dates. Additional data on the $10^{\text {th }}$ Mountain Division's locations were obtained from Imbrie and Imbrie (2004). For each WWII ground division that fought in the European or Mediterranean Theaters, these data were hand-entered into a spreadsheet of 1,565 different division-date-location combinations for 67 U.S. divisions. The geographic coordinates of different cities were obtained from Google Earth and from U.S. National Geospatial-Intelligence Agency (2007), with all cases double-checked using Google Earth. For cases in which multiple cities had the same name, the city was selected that was closest to the cities visited before and after. Location was not known for most dates and divisions - for in-between dates, each division's was interpolated assuming that longitude and latitude changed linearly at a constant speed from one location to the next. The 1,565 total includes observations that were added to the data to insure that travel along a straight line would keep the observation on land.

Non-U.S. Allied Unit Locations. The Allied countries other than the U.S. whose divisions' are tracked in these data include Australia (Haskew, 2009; Maughan, 1966; Natkiel, 1999; Pimlott, 2006; Wikipedia, 2010a), Brazil (McCann, 1974; Moraeas, 1966) Canada (Copp, 2006; Natkiel, 2006; Pimlott, 2006; Nicholson, 1956; Wikipedia, 2010b), France (including Algeria and Morocco, Natkiel, 2006; Pimlott, 2006; Stone, 1999, Wikipedia, 2010c), India (Joslen, 2009), New Zealand (Kay, 1967; Llewellyn, 1949; McKinney, 1952; Natkiel, 2006; Phillips, 1957; Pimlott, 2006; Wikipedia, 2010d), Poland (Copp 2006; Natkiel, 2006; Nicholson, 1956; Pimlott, 2006), South Africa (Joslen, 2009; Pimlott, 2006), and the United Kingdom (Joslen, 2009). These sources include published orders of battle, official histories, atlases of WWII, and some online sources. Countries such as Greece that only provided non-divisional units or those such as Czechoslovakia or the Philippines that did not serve on the Western front are excluded from the analysis. Italy, which had only a limited military presence in the Allies following its withdrawal from the Axis, is also excluded. The approaches for identifying the coordinates and imputing are the same as for the U.S. divisions.

Axis Unit Locations. German and Italian force locations were obtained from a variety of sources, among them published orders of battle, unit histories, memoirs, and atlases of WWII (Axis History Factbook, 2009; Bishop and McNab, 2003; Dupuy, 1962; Dupuy, Bongard, and Anderson, 1994; Evans, 2002; Howe, 1993; Jordan and Wiest, 2004; Keegan, 2006; Kurowski, 1995; Messenger, 1989; H. Meyer, 2005; K. Meyer, 2005; Mitcham, 2007a, 2007b, 2007c, 2007d, 1985; Natkiel, 2006; Pimlott, 2006; Terry and Cole, 2001a, 2001b; von Luck, 1989, von Mellenthin, 1956; Zetterling, 2000). The German list of divisions was obtained from Mitcham (2007a, 2007b, 2007c, and 2007d), and the Italian list of divisions was obtained from Axis History Factbook (2009). In many cases, divisions' locations were identified from a higher level of organization such as the Army or corps together with information from Axis History Factbook (2009) on the Axis Army's organizational structure. A total 5,082 different division-location combinations were obtained from these sources, with coordinates identified and in between locations imputed in the same way as for the Allied divisions. Vichy France was not included in the data collection because its opposition to Allied forces only lasted for a brief time in November 1942. 


\section{Geographic Variables}

The key geographic variables used in the division by day panel are those measuring terrain, weather, and vegetation. Additionally, the cost distance tool in ArcGIS was used to determine land distances from one location to another.

Terrain (U.S. Geological Survey, 2005). Elevation data for Europe and North Africa were obtained from U.S. Geological Survey (USGS, 2005). These data were compiled by NASA and USGS from space shuttle photographs taken in 2000 and consist of elevation values at points spaced 3 arc seconds (roughly 90 meters) apart from one another along a grid. The slope at a given point is calculated using the slope tool in ArcGIS. This tool measures the change in elevation (in degrees) between each point and its eight neighbors (north, northeast, etc.) and returns the steepest (up or down) of these eight different slopes. This slope variable is commonly used by geographers as a measure of the difficulty of traveling over terrain in a given area.

Weather (Mitchell and Jones, 2005). Historical weather data are taken from the Climactic Research Unit's CRU TS 2.1 Global Climate Database. These data measure near-surface mean temperature, precipitation, number of wet days, and other variables by month and year at the 0.5 $\mathrm{x}$ 0.5-coordinate level for the entire world going back to 1901. The set of weather stations used to construct the data varies from year to year, and imputation and climate modeling is used to fill in missing observations. In addition to the imputation used to construct the data, an additional 549 observations in the division by day panel required imputing the weather variables as averages of the neighboring cells that month.

Vegetation (Goldewijk, 2001). The vegetation data used in this study are estimates that were compiled by the author of the dataset for every fifty years from historical surveys such as tax records and land surveys. The data place each $0.5 \times 0.5$-coordinate cell into one of twenty land use categories based on the amount of vegetation. The 1950 data are used for the current study. The "cultivated land" dummy used in the division by day panel is one of the twenty categories, and the "wooded or mixed" dummy indicates whether that 0.5 by 0.5 -coordinate cell was in one of the eight land cover categories whose description included the word "wood" or "forest."

\section{Engagement Data}

The engagement data used in this study are the result of a long-term data compilation effort by The Dupuy Institute and its predecessor organization, the Historical Evaluation and Research Organization (HERO) that began in the 1960s. The Dupuy Institute's Division-Level Engagement Database (DLEDB) is a cleaned and expanded version of an earlier database entitled the Land Warfare Database (LWDB). Both datasets include a large number of battles from antiquity to the present and have been analyzed as a set by a handful of economists and operations researchers including Hartley (2001), Helmbold (1993), and Rotte and Schmidt (2003). The data are described in detail in The Dupuy Institute (2001a, 2005). Additionally, the dataset as a whole and many specific observations are described in greater detail and examined from the perspective of quantitative historians in sources such as Dupuy $(1985,1987,1995)$, Lawrence (1996, 1997), and The Dupuy Institute (2000, 2001b, 2004b). The LWDB is publicly 
available as a CD-ROM in the back of Hartley (2001). The DLEDB is proprietary and may be purchased from The Dupuy Institute.

One of the key variables from the engagement data used in this study that appears both in the DLEDB and in the LWDB is the subjective index of mission accomplishment. Figure A2 shows the worksheet used to calculate this zero to one mission accomplishment index. As the figure shows, each unit is scored on five criteria. The first three criteria relate to specific mission objectives. These include conceptual accomplishment (a general evaluation of achievement of mission objectives), geographical accomplishment (i.e., kilometers advanced), and block hostile mission. Together, these objective-based scores can range from zero to six. In addition to these three objective-based measures, the index incorporates general evaluations of the performance of officers and enlisted men. Together these general evaluations can range from zero to four points. In principle, each side's mission accomplishment can be evaluated separately and ranges from zero to ten. In practice, attacker and defender mission accomplishment are nearly perfectly negatively correlated. Mission accomplishment ratings do not exceed nine for either side for the 162 engagements used from the DLEDB. The measure of mission accomplishment used in this study and in the previous section is (U.S. total score-German total score)/16.

One limitation of this subjective mission accomplishment measure is that it assigns equal weight to each of the five criteria. Ideally, it would be possible to vary the weights for these criteria depending on their relative importance in different missions. Another possible limitation of this subjective mission accomplishment measure is the emphasis on troops. Command and staff performance and troop performance are both rated separately from accomplishment of specific objectives. No such rating exists, however, for the performance of capital. Given the available measures, this subjective index appears to be the best way to quantify mission accomplishment.

\section{Cost Calculations}

As discussed in the text of the paper, the per troop and per tank cost estimates are derived from estimates of the cost of raising and operating an organic infantry and armored division according to the 1942 configurations. These costs take into account pay, training, capital expenses, depreciation, food, clothing, gasoline, ammunition, and transportation. The costs calculated here include all costs incurred between the activation of a division and its return from overseas, including the return trip. These estimates omit many overhead expenditures such as planning and research and development. While all the Army divisions benefited from these expenditures, these costs do not have to be paid again when replacing a division.

Table A13 shows estimated total wartime costs for infantry and armored divisions that spent typical amounts of time abroad. All cost estimates are expressed in 2009 dollars and are converted using the Consumer Price Index. The costs shown in Table A13 are calculated using separate estimates of a typical division's fixed costs plus additional costs per months abroad. For most major expenditure categories, these estimated costs are very similar for infantry and armored divisions. The biggest cost differences between the two types of divisions are for equipment and transportation. For an infantry division, equipment costs totaled $\$ 119.80$ million initially plus $\$ 4.30$ million per month abroad. For an infantry division, equipment cost about ten 
times as much at $\$ 1.114$ billion initially plus $\$ 71.00$ million per month abroad. For a 10.8 -month deployment, we find that a 1942 organic infantry division cost $\$ 1.43$ billion and a 1942 organic armored division cost $\$ 4.10$ billion.

\section{Dates of Service and Dates Abroad}

Activation and de-activation dates and dates abroad for each division are taken from Stanton (1984, pp. 47-182). The number of months in the theater for the average division is computed from the division by day panel as 10.76 . The average number of days in the theater for the average division is computed as 298.8 .

\section{Pay and Allowances}

To compute pay rates for different soldiers, official pay scales are used from the Pay Readjustment Act of 1942 (U.S. Congress, 1942). This document provides the pay scales for military personnel based on rank, tenure, and special circumstances (e.g., additional skills or overseas service). Assumptions about skills are described later in this appendix. The rank composition of infantry and armored divisions is obtained from Hays (2004, 2002).

Because pay depends on tenure, a level of tenure is assumed for each troop. These assumptions about tenure have little effect on the final cost figures but are necessary to obtain wage estimates. The vast majority of officers and enlisted men who fought in World War II were inducted from civilian life (Palmer, Wiley, and Keast, 1991, pp. 91-92). However, the higher-ranking officers were typically career military. It is assumed that men in the core officer cadre (described below) had the average tenure levels for their ranks. It is assumed that other officers and enlisted men had zero tenure when they underwent training. After training was complete, it is supposed that all these troops had the average tenure levels for their ranks. It is also assumed that the division had this same post-training tenure composition throughout the life of the unit. Average tenure levels for officers are estimated using average pay data from U.S. War Department Bureau of the Budget (1946). Given average pay and the formula relating pay to tenure (from U.S. Congress, 1946), average tenure levels are imputed for each rank. A similar exercise is performed for enlisted men using average pay data from U.S. Army Office of the Comptroller (1953). Using pay scales from U.S. Defense Finance and Accounting Service (2006), average tenure for enlisted men is estimated by rank for 1953. These 1946 and 1953 average tenure levels are used to proxy for average tenure in 1942, the year of interest.

During World War II, retirement pay was limited to officers who had served for at least 10 years (U.S. Congress, 1942, pg. 368, U.S. Congress, pg. 773). These men would have probably been employed in the absence of the war. Veterans' benefits were expanded later on, but it is likely that these changes were unanticipated at the time that the troops were procured. Consequently, retirement pay and other veterans' benefits are not counted for the purposes of this exercise. 


\section{Training}

Initial (pre-departure) training expenditure calculations begin with the January 1942 plan for activation of an infantry division (Palmer, Wiley, and Keast, 1991, pp. 433-441). This plan specifies the lengths of time spent in training for all 15,514 troops in an organic infantry division. It is assumed that the sequence of events in activation and training was the same for armored as for infantry divisions. A division usually began with a cadre of trained, high ranking officers taken from other "parent" divisions. For infantry divisions, this cadre included 172 officers. ${ }^{16}$ Given the larger numbers of high ranking officers in an armored division, it is assumed that the armored officer cadre included 183 officers. ${ }^{17}$

The high ranking officers within a division acted as instructors for most of the division's training. This training included both basic instruction and field exercises performed at camps throughout the U.S. Palmer, Wiley, and Keast suggest that the typical training period for a division was 38 weeks (Palmer, Wiley, and Keast, 1991, pp. 440-441, 481). Data from Stanton indicate that 789 and 803 days passed between activation and departure overseas for armored and infantry divisions, respectively (Stanton, $1984 \mathrm{pp}$. 47-182). Hence, the divisions spent a considerable amount of time after training simply shuffling around and waiting to depart. ${ }^{18}$ The personnel costs in Table A13 include wages paid during this idle time. Most of the division's pre-debarkation wages are included as personnel costs in Table A13, even when the personnel worked as instructors. ${ }^{19}$

The total costs of division field exercises are calculated from U.S. Bureau of the Budget (1940-1947). ${ }^{20}$ The cost per set of maneuvers is estimated by dividing this total cost across all divisions in proportion to their participation. Stanton (1984) reports the dates in which each division participated in field exercises. The average armored and non-armored divisions participated in 1.6 and 2.0 sets of combat maneuvers, respectively. It is assumed that the armored: infantry cost ratio for field exercises was 1.25 , the same as for replacement training camps. Estimates of replacement training camp costs are described later in the appendix.

\footnotetext{
${ }^{16}$ Later in 1942, the activation schedule was changed slightly, and a greater proportion of officers were hired for the pre-trained cadre (Palmer, Wiley, and Keast, 1991, pp. 436-438). Accounting for such changes would have only a minor effect on our estimated costs.

${ }^{17}$ This estimate is obtained by assuming that the ratio of cadre to other officers was the same as for the infantry division.

${ }^{18}$ Brown (1986, pp. 164-167) describes this process in further detail.

${ }^{19}$ For training before the division was activated (e.g., basic enlisted training, Officer Candidate School), trainee wages are included in the cost of training. It is supposed that basic training for enlisted men and officers occurred prior to activation of the division. Hence, the total costs of basic, officer, and Command and General Staff training include the wages and allowances paid to trainees. Advanced training appears to have frequently taken place after the activation of the division (Palmer, Wiley, and Keast, 1991, pg. 265). Hence, these men would have been employed by the division if they were not receiving the training. The cost of advanced training estimated here excludes trainees' wages and allowances. It is supposed that troops held the rank of Private during basic enlisted training and Private First Class during officer candidate training. It is supposed that they held the rank of Second Lieutenant during Command and General Staff Training. During all other training, it is supposed that the trainees held their ultimate ranks within the division.

${ }^{20}$ These estimates exclude the costs of additional military personnel who worked at the training camps. From preliminary investigations, It was determined that these additional costs are negligible.
} 
All the officers and some of the enlisted men received training prior to the activation of the division. ${ }^{21}$ Every officer received both basic enlisted training and some form of basic officer candidate training. The higher ranking enlisted men received basic enlisted training before joining the division. Roughly $33 \%$ of the officers and roughly $6 \%$ of the enlisted men also received advanced training in some special skill. ${ }^{22}$ Troops within the division served different functions (e.g., Artillery, Infantry, Quartermaster), and each troop attended schools particular to his branch. Data on the breakdown of infantry and armored divisions by branch are taken from Hays (2004, 2002) and Greenfield, Palmer, and Wiley (1947, pp. 320-321).

Next, the lengths and types of training are estimated for each troop. Troops were generally processed through induction stations and reception centers. Each of these processes lasted a day or two (U.S. Army Chief of Staff, 1945a). From early in mobilization until April 1943, basic enlisted training lasted 13 weeks. Officer candidate school also typically lasted about 13 weeks during this period. By late 1943, both types of schooling had been lengthened to 17 weeks (Palmer, Wiley, and Keast, 1991, pp. 332, 358, 382-385). For the purposes of this analysis, it is assumed that the divisions' initial troops received the shorter, 13-week training. Replacement troops are assumed to have received the longer training. Specialist courses varied in length. For each troop, it is assumed that specialist training lasted the average length for enlisted or officers for that branch. These average lengths are calculated using course lengths and output data from Palmer, Wiley and Keast (1991, pp. 309-319). ${ }^{23}$ Some specialist course lengths are also taken from U.S. Army Ground Forces (1947). It is also supposed that the divisions' highest ranking officers attended Fort Leavenworth's 10-week Command and General Staff course. ${ }^{24}$

Next, the cost per week of training is estimated for different types of training. Estimates of the cost per week of officer training are obtained from U.S. Army Ground Forces (1947). This report consists of an itemized accounting of different types of training given to Chinese officers in 1947. This report includes the estimated costs and lengths for a variety of courses in

\footnotetext{
${ }^{21}$ The original officer cadre included officers who had already received training for other purposes. These officers were often taken from other "parent divisions." The cost of the division does not include the cost of training these officers. However, the division was responsible for training replacements for the officer cadre in their parent divisions. These replacement training costs are included in the cost of the division.

${ }^{22}$ It is supposed that advanced training went to higher ranking officers and enlisted men and to the ranks with "technical" in the title. Both the 33\% and 6\% figures are rough approximations based on a variety of figures (Palmer, Wiley, and Keast 1991, pp. 249, 266, 279, 308-319). For an enlisted man who learned a special skill, the Army paid an additional allowance. It is assumed here that this bonus coincided with taking the enlisted advanced courses.

${ }^{23}$ For the Officer Candidate School basic training, total training costs include the cost of training students who did not graduate. These costs are added in by scaling the course length by the branch-specific graduation rate. Data on graduation rates are obtained for the branches of the ground arms (e.g., Artillery, Armor, Infantry) from Keast (1946, pp. 27-34). Data on the overall graduation rate of the service branches (e.g., Ordnance, Signal, Quartermaster) are obtained from U.S. Army Service Forces (1954, pg. 224). We assume that the Command and General Staff graduation rate equaled the average graduation rate for basic officer courses in the ground arms. For the basic enlisted training, it is assumed that the induction centers effectively screened enlisted men, and that the graduation rate was $100 \%$. For advanced courses, it is assumed that the knowledge (rather than the degree) was relevant for division effectiveness, and hence pass rates are ignored.

${ }^{24}$ During World War II, the typical 1- to 2-year course was abbreviated to 10 weeks (Partin, 1983).
} 
ground arms, service branches, and Command and General Staff. ${ }^{25}$ It is assumed that the advanced specialist courses cost as much for enlisted men as for officers. To estimate the cost per week for basic enlisted training, these costs are combined with data from a few different sources. ${ }^{26}$ Some minor imputation was required in calculating each of breakdown by branch, course lengths, and cost per week.

In addition to the initial mobilization strength, each division received replacement troops when it lost troops due to casualties or other separations. The cost of regular replacements of troops is estimated by combining the above pay and training estimates with data on separations. Casualty rates, separation rates, and returns to duty (among casualties) are measured separately for officers and enlisted men from a handful of sources. For separations other than casualties, the cost of replacements is included in the monthly cost of operating a division overseas. Data on the rate of separations are obtained from U.S. Army Service Forces (1954, pp. 200, 206-209). Data on the rate of casualties (minus returns-to-duty) are obtained from U.S. Army Adjutant General (1953, pg. 5). Using these data, the monthly rates of non-casualty separations are calculated separately for officers and enlisted men. Within each enlisted/officer and branch combination, it is assumed that replacements took specialist courses at the same rate as the division's original troops. However, replacements generally did not receive divisional training or participate in maneuvers. For casualty replacements, the casualty rate per branch is estimated from a handful of sources. ${ }^{27}$ Using these pay and training data, the replacement cost per casualty is estimated to be $\$ 6,400$. This cost of replacing casualties is not included in the estimated costs of the divisions. Death benefits and funeral and cemetery expenses were negligible compared to this $\$ 6,400$ replacement cost (U.S. Bureau of the Budget, 1940-1947; U.S. Congress, 1919).

\section{Capital Expenditure}

Quantities of equipment for organic infantry and armored divisions are taken from Hays (2004, 2002). Purchase prices for each item are taken from U.S. Army price lists (U.S. Army Air Forces, 1945; U.S. Army Service Forces (1942a, 1942b, 1943a, 1943b, 1943c, 1944a; U.S.

\footnotetext{
${ }^{25}$ We also constructed our own estimates of the average training costs per pupil based on the schools' non-personnel budgets and the total personnel. Our estimates are slightly larger than these cost estimates, but are generally of the same order of magnitude. The Army Ground Forces data are used for the final estimates, because they exhibited less variance and required fewer assumptions.

${ }^{26}$ For each branch, it is assumed that the non-labor cost per pupil was the same for officer training as for enlisted training. Non-labor costs for the officer candidate schools are obtained from U.S. Bureau of the Budget (19401947). It is then assumed that the personnel cost per pupil was proportional to the number of personnel per pupil in each school. The personnel per pupil for enlisted and officer schools are obtained from U.S. Army Chief of Staff (1945a through 1945d). It is supposed that the labor cost per employee was the same for these schools as for the corresponding branch of officer training. For the service branches, data on non-labor costs were not readily available. It is assumed that the non-labor cost per pupil in the Signal Corps was the same as for Field Artillery. It is also assumed that the non-labor cost per pupil for Ordnance and the Quartermaster Corps were the same as for Infantry. For the Medical Corps, the personnel to student ratio was very similar for basic enlisted and enlisted specialist schools. Consequently, it is assumed that the cost per trainee week was the same for officers and enlisted men. For Military Police and Engineer Corps, personnel to student ratios are not readily available for both officer and enlisted courses. For these two branches, it is assumed that the cost per trainee week was the same for enlisted men as for officers.

${ }^{27}$ U.S. Army Adjutant General (1953), pg. 5. Palmer, Wiley, and Keast (1991), pg. 49. U.S. Army Service Forces (1954), pg. 123. Some branches aggregated. Some minor imputation required. It is supposed that the ratio of enlisted to officer casualties was constant across the different ground arms and service branches.
} 
Army Services of Supply 1942a, 1942b). These prices are adjusted using branch-specific monthly procurement price indices from Crawford and Cook (1953, pg. 82). Depreciation rates for specific capital items are taken from U.S. Army Service Forces (1943d, 1944b, 1944c) estimates. These depreciation rates take into account tank losses both in and out of combat. ${ }^{28}$ In many cases, Army Service Forces estimated separate depreciation rates for different theaters. When separate depreciation rates were available for the Mediterranean and European Theaters of Operations, an average of the two rates was used. When this was not possible, depreciation rates were used for the overall Western Front or for the entire overseas army. Maintenance and loss data from overseas were limited, and these estimated depreciation rates are at best very rough approximations. In a small handful of cases, the price or depreciation rate for a specific item was not available. In these cases, the data for similar items were used. For the 38 weeks of division training, it is supposed that equipment depreciated at the reported rates for the Continental U.S. This depreciation is counted as a cost of training in Table A13. For the remaining idle time before debarkation, it is supposed that equipment did not depreciate.

The effects of division type on tank losses in Table A6 are notable because they are used in the cost calculations. For the average combat day in the engagement data, 3.4 out of 125 U.S. tanks were lost in combat. The percentage lost in a combat day was $1.1 \%$ and $2.8 \%$ for pre- and post-reorganization infantry and was $3.5 \%$ and $4.6 \%$ for pre- and post-reorganization armored. To translate these figures into estimated losses per month, we multiply these percent losses by the number of days in the engagement sample that a unit would be expected to experience over a month. We then scale the losses upward to account for tank losses that occurred on days that are not in the engagement sample. Because tank loss data are only available in the engagement sample, we perform a scaling using the fatalities data - measuring the fraction of deaths attributable to engagement days. This same scaling is used to construct the U.S. KIA bar graphs and the isoquant graphs in the main paper. To perform the scaling, we multiply the percentage of tanks lost by 298.803 (the number of days in a typical deployment) times 0.0146544 (the fraction of division days included in the engagement sample) and we divide by the product of 0.0589803 (the fraction of deaths accounted for by the engagement sample) and 10.75758 (the number of months in a typical deployment). For the infantry divisions, this calculation produces monthly loss rates of $7.83 \%$ pre-reorganization and $19.3 \%$ post-reorganization. For the armored divisions, this calculation produces monthly loss rates of $24.0 \%$ pre-reorganization and $31.7 \%$ post-reorganization. The differences between pre- and post-reorganization types are largely due to the more intense combat and higher tank losses experienced in the ETO than in the Mediterranean Theater. Considering pre- and post-reorganization together, we estimate monthly tank losses of $11.2 \%$ for the infantry division and $29.8 \%$ for the armored division. Army Service Forces varied its tank loss estimates over the course of the war based on the higher than anticipated loss rates; these figures are roughly in line with their end-of-war estimated loss rate of $20 \%$ (Smith, 1959, pp. 189-91). Given the lower percentage of armored divisions in the theater, the observed tank loss rates fall slightly below this $20 \%$ figure; however, the loss rates from the engagement data do not take into account standard wear and tear and tank losses that

\footnotetext{
${ }^{28}$ Constant monthly depreciation rates are assumed, as U.S. Army Service Forces did when determining replacement requirements. These depreciation rates take into account tank losses from combat. Simply using tank loss rates from the engagement data would fail to account for tank losses out of combat. Moreover, the engagementlevel tank loss data do not specify the degree of damage or reparability. These constant monthly depreciation rates appear to be the most accurate way to account for tank losses.
} 
did not occur during combat (which probably occurred more frequently than non-combat fatalities). To adjust for this deficiency, the monthly depreciation rates from Army Service Forces are revised upwards in the tank loss estimates, and a $15 \%$ monthly depreciation rate is assumed for tanks in infantry divisions, and a 35\% monthly depreciation rate is assumed for armored divisions.

\section{Food, Clothing, Gasoline, and Ammunition}

The food, clothing, gasoline, and ammunition costs estimated here rely on historical U.S. Army cost studies. Estimates of a single troop's food requirements are taken from U.S. War Department Public Relations Division (1946). Clothing and additional equipment estimates are taken from U.S. Army Office of the Quartermaster General (1944). ${ }^{29}$ Both per troop estimates are then multiplied by the number of men in each type of division. Monthly overseas ammunition cost estimates for a 1942 armored and infantry division are obtained from U.S. Army Services of Supply (1943, pg. 30). Monthly overseas gasoline requirements for a 1942 armored and infantry division are obtained from U.S. Army Service Forces (1943a). ${ }^{30}$ Gasoline prices for 1942 are taken from U.S. Bureau of Labor Statistics (2004).

\section{Transportation}

Transportation costs are estimated separately for troops and for capital items from the travel and transportation portions of the U.S. defense budget (Greenfield, Palmer, and Wiley, 1947, pg. 203; U.S. Bureau of the Budget, 1940 to 1947). ${ }^{31}$ These expenses are divided by the total numbers of people and tons shipped overseas to obtain average costs per person and per ton (U.S. Army Service Forces, 1954, pp. 116, 123). Hence, it is assumed that the per person and per ton transport costs were the same for the Pacific and Western Fronts. These costs include the total expenditures incurred by the Transportation Corps for inter- and intra-continental transport for people and items shipped overseas. Given all these assumptions, the total transportation cost per ton shipped overseas is estimated to be $\$ 880$ in 2009 dollars. The total transportation cost per troop who traveled overseas is estimated to be $\$ 3,600$.

The total weight of infantry and armored divisions' equipment is taken from U.S. Army Service Forces (1943a). Two-way trips are assumed for initial troops and equipment, and oneway trips are assumed for replacements. It is assumed that maintenance shipments had the same weight per dollar of expenditure as the initial shipments did. In addition to regular purchases, Army supply plans included a 4.5-month store of reserves. ${ }^{32}$ Hence, 4.5 months of equipment,

\footnotetext{
${ }^{29}$ These Quartermaster General estimates include both initial costs and monthly maintenance costs. These totals include "additional equipment" such as canteens, flashlights, etc. These costs are added to the "Equipment" category in Table A13. As suggested by the study, the estimates here add $25 \%$ of the initial costs for reserve requirements.

30 These studies do not report monthly ammunition or gasoline requirements for units still in the U.S. To compute U.S. rates, it is supposed that the ratio of gasoline and ammunition usage to capital depreciation was the same as it was overseas.

${ }^{31}$ Personnel costs for the Transportation and Quartermaster Corps are calculated assuming that employees in these branches received the average Army pay rates.

${ }^{32}$ Supplies ran very low near the end of the war. As Anderson (2000) describes, to supply units in the field, some divisions were stripped of their equipment as soon as they arrived overseas. Hence, the true amounts of reserves
} 
gasoline, and ammunition are added to the fixed cost of each division type. Costs are also adjusted for 2\% shipping losses for all equipment, as suggested in Herbert and Richards (1943, pg. 21). ${ }^{33}$

\section{Numbers of Troops and Tanks}

The standard numbers of troops and tanks for each division type varied over time and are illustrated in Figure A3. The solid black line in panel A shows the number of troops for an armored division, the dashed line shows the number for an infantry division, and the solid gray line shows the number for an airborne division. The standard numbers of tanks are plotted in panel B; however, only the solid black line for the armored division is visible, because no tanks were allotted to the standard infantry or airborne divisions. The numbers for Figure A3 come from Hays (2002, 2003a, 2003b, 2004) and many were confirmed in Stanton (1984) and Wilson (1998).

To measure the numbers of troops and tanks once attachments are taken into account, the full attachment histories are taken from U.S. Army ETO (1945), which lists each U.S. division's history of attachments and detachments over its time in the European Theater. For each of the different platoons, companies, troops, squadrons, battalions, and regiments that were attached and detached, the standard numbers of troops were identified from the same sources listed in the previous paragraph.

maintained overseas may have fell considerably lower than this 4.5 months figure. Denson and Wood (1943, pg. 21). One additional cost of reserves is the cost of storage space. A preliminary examination of storage costs revealed that they were negligible. Sources: Hamilton (1953), pg. 28; U.S. Army Ground Forces (1945); U.S. Army Service Forces (1943e), pp. 27-B to 29-B; U.S. Army Service Forces (1954, pp. 106-110). U.S. War Department Office of the Budget Officer (1943).

${ }^{33}$ In other words, all equipment costs are divided by 0.98 to allow for shipping losses. 


\section{References}

Anderson, Richard C., Jr. "The U.S. Army in World War II.” Military History Online, 2000. $<$ http://www.militaryhistoryonline.com/wwii/usarmy/default.aspx $>$

Axis History Factbook. 2009. "Military Organisations: Heer." Available at: http://www.axishistory.com/index.php?id=30

Bishop, Chris and Chris McNab. 2003. The campaigns of World War II day by day. Hauppauge, NY: Barron's Educational Series.

Brown, John Sloan. Draftee division. Lexington, KY: The University Press of Kentucky, 1986.

Copp, J. Terry. 2006. Cinderella army: the Canadians in Northwest Europe. Toronto:

University of Toronto Press.

Crawford, Richard H. and Cook, Lindsley F. "Procurement." In Whiting, Theodore E., ed., Statistics. United States Army in World War II (Green Book Series). Unpublished Manuscript. United States Army Center of Military History, 1953. Center of Military History Library Call No. 2-3.7/AA.W.

Dupuy, Trevor N. 1962. The military history of World War II: Volume 3, Land Battles: North Africa, Sicily, and Italy. New York: Franklin Watts, Inc.

Dupuy, Trevor N. Numbers, prediction, and war. Fairfax, VA: HERO Books, 1985.

Dupuy, Trevor N. Understanding war. New York: Paragon House, 1987.

Dupuy, Trevor N. Attrition: Forecasting Battle Casualties and Equipment Losses in Modern War. Nova Publications. Falls Church, VA. 1995.

Dupuy, Trevor N., David L. Bongard, and Richard C. Anderson, Jr. 1994. Hitler's last gamble: the battle of the bulge, December 1944-January 1945. New York: Harper-Collins Publishers.

The Dupuy Institute. "Capture Rate Study Phases I and II Final Report," Produced for Center for Army Analysis. Annandale, VA. March 2000.

Available at: http://www.dupuyinstitute.org/pdf/e-4epw1 and2final.pdf

The Dupuy Institute. User Guides for the Dupuy Institute Databases. Annandale, VA. September 2001a.

The Dupuy Institute. The Historical Combat Effectiveness of Lighter-Weight Armored Forces. Annandale, VA. August 2001b.

Available at : http ://www.dupuyinstitute.org/pdf/mwa-2lightarmor.pdf

The Dupuy Institute. Division-level engagement database. The Dupuy Institute, 2004a. 
The Dupuy Institute. Measuring the Value of Situational Awareness. Annandale, VA. February $2004 b$.

The Dupuy Institute. "Appendix M: Representativeness of the DLEDB." Forecast of Future Casualties in Iraq. Annandale, VA. January 2005.

Evans, Martin Marix. Battles of World War II. Shrewsbury, England: Airlife Publishing, Ltd., 2002.

Goldewijk, Klein K., 2001. Estimating global land use change over the past 300

years: The HYDE database, Global Biogeochemical Cycles 15(2): 417-433.

Greenfield, Kent R.; Palmer, Robert R. and Wiley, Bell I. The organization of ground combat troops. United States Army in World War II (Green Book Series). Washington, DC: Historical Division, Department of the Army, 1947 (reprinted 1987).

Hamilton, William A., Jr. "Construction and Real Estate." In Whiting, Theodore E., ed., Statistics. United States Army in World War II (Green Book Series). Unpublished Manuscript. United States Army Center of Military History, 1953. Center of Military History Library Call No. 2-3.7/AA.W.

Hartley, Dean S., III. 2001. Topics in operations research: predicting combat effects. Institute for Operations Research and the Management Sciences. Baltimore, MD. 2001.

Note: includes CD with Land Warfare Database

Haskew, Michael E. 2009. "Order of Battle Western Allied Forces of WWII." London: Amber Books, Ltd.

Hays, Jack J. United State Army Ground Forces tables of organization and equipment, World War II, volume 2: The armored division 1940-1945, part 2. Milton Keynes, England: Military Press, 2004.

Hays, Jack J. United State Army Ground Forces tables of organization and equipment, World War II, volume 3: The airborne division 1942-1945, part 1. Milton Keynes, England: Military Press, 2003a.

Hays, Jack J. United State Army Ground Forces tables of organization and equipment, World War II, volume 3: The airborne division 1940-1945, part 2. Milton Keynes, England: Military Press, $2003 b$.

Hays, Jack J. United State Army Ground Forces tables of organization and equipment, World War II, volume 1: The infantry division 1940-1945, part 1. Milton Keynes, England: Military Press, 2002. 
Helmbold, Robert L. “Combat Analysis.” Phalanx, Vol. 26, No.3. Military Operations Research Society, Alexandria, VA. September 1993.

Hensel, H. Struve and McClung, Richard G. "Profit Limitation Controls Prior to the Present War." Law and Contemporary Problems, Winter 1944. 10(2), pp. 187-217.

Herbert, James K. and Richards, George J. "Notes on Presentation of Requirements Division Before Procurement Review Board: Army Supply Program and Matters Related to Requirements Division.” United States. Army Service Forces, 1943. Record Group 160, Entry 94, Box 697 and Entry 88, Box 580. National Archives II Building, College Park, MD. Note: Original presentation by Denson, Lee A. and Wood, Walter A., Jr.

Howe, George F. 1993. United States Army in World War II: The Mediterranean Theater of Operations: Northwest Africa: seizing the initiative in the West. Washington, DC: United States Army Center of Military History.

Imbrie, John and Barbara Imbrie. 2004. "Chronology of the $10^{\text {th }}$ Mountain Division in World War II, 6 January 1940 to 30 November 1945." Lakewood, Colorado: National Association of the $10^{\text {th }}$ Mountain Division Association. Available at:

http://10thmtndivassoc.org/chronology.pdf

Jordan, David and Andrew Wiest. 2004. Atlas of World War II. London: Amber Books, Ltd.

Joslen, H.F. 2009. Orders of battle: United Kingdom and colonial formations and units in the Second World War 1939-1945. London: Naval and Military Press (new edition of 1960 printing).

Kay, Robin L. 1967. Official history of New Zealand in the Second World War 1939-45. Italy Volume II: From Cassino to Trieste. Wellington, New Zealand: R.E. Owen, Government Printer.

Keast, William R. "Training of Officer Candidates in AGF Special Training Schools." Study No. 31. Historical Section, United States Army Ground Forces, 1946. Center of Military History Library Call No. D 769 A5331 no. 31.

Keegan, John. 2006. Atlas of World War II. London: Harper-Collins Publishers.

Kurowski, Franz. 1995. The history of the Fallschirmpanzerkorps Herman Göring. Winnipeg, Canada: J.J. Fedorowicz Publishing, Inc.

Lawrence, Christopher. "The Second Test of the TNDM Battalion-Level Validations: Predicting Casualties." The International TNDM Newsletter. April, 1997.

Available at: http://www.dupuyinstitute.org/tdipub4.htm

Lawrence, Christopher A. "The Velocity Attrition Factor." The International TNDM Newsletter, October 1996, 1(2), pg. 64. 
Llewellyn, Stephen P. 1949. Official history of New Zealand in the Second World War 1939-45. Journey Towards Christmas: Official History of the $1^{\text {st }}$ Ammunition Company Second New Zealand Expeditionary Force, 1939-1945. Wellington, New Zealand: War History Branch, Department of Internal Affairs. Printed by Dunedin, New Zealand: Coulls Somerville Wilkie, Ltd.

Maughan, Barton. 1966. Australian in the War of 1939-1945: Series 1 - Army, Volume III Tobruk and El Alamein.

McCann, Frank D. 1974. The Brazilian-American Alliance, 1937-1945. Princeton, NJ: Princeton University Press.

McKinney, J.B. 1952. Official history of New Zealand in the Second World War 1939-45. Medical Units of 2 NZEF in Middle East and Italy. Wellington, New Zealand: War History Branch, Department of Internal Affairs. Printed by Dunedin, New Zealand: Coulls Somerville Wilkie, Ltd.

Messenger, Charles. 1989. The chronological atlas of World War Two. New York: MacMillan.

Meyer, Hubert. 2005. The $12^{\text {th }}$ SS: The history of the Hitler Youth Panzer Division: Volume Two. Mechanicsburg, PA: Stackpole Books.

Meyer, Kurt. 2005. Grenadiers: The story of Waffen SS general Kurt "Panzer” Meyer. Mechanicsburg, PA: Stackpole Books.

Mitcham, Samuel W., Jr. 2007a. German order of battle volume one: $1^{\text {st }}-290^{\text {th }}$ Infantry Divisions in WWII. Mechanicsburg, PA: Stackpole Books.

Mitcham, Samuel W., Jr. 2007b. German order of battle volume two: 291 ${ }^{\text {st }}-999^{\text {th }}$ Infantry Divisions, named infantry divisions, and special divisions in WWII. Mechanicsburg, PA: Stackpole Books.

Mitcham, Samuel W., Jr. 2007c. German order of battle volume three: Panzer, Panzer Grenadier, and Waffen SS Divisions in WWII. Mechanicsburg, PA: Stackpole Books.

Mitcham, Samuel W., Jr. 2007d. The Panzer Legions: A guide to the German Army tank divisions of WWII and their commanders. Mechanicsburg, PA: Stackpole Books.

Mitcham, Samuel W., Jr. 1985. Hitler's legions: the German Army order of battle. New York: Stein and Day.

Mitchell, T.D. and Jones, P.D. 2005. "An improved method of constructing a database of monthly climate observations and associated high-resolution grids." Int. J. Climatol. 25: 693 712 . 
Moraes, Joao Baptista Mascarenhas de. 1966. Brazilian Expeditionary Force, by its commander. Translated from $2^{\text {nd }}$ Ed, revised and enlarged. Washington, DC: U.S. Government Printing Office.

Natkiel, Richard. 2006. The atlas of World War II. North Dighton, MA: JG Press, Inc.

Nicholson, Gerald W. L. 1956. Canadians in Italy 1943-1945. Ottawa, Canada: Queen's Printer and Controller of Stationery.

Palmer, Robert R.; Wiley, Bell I. and Keast, William R. The procurement and training of ground combat troops. United States Army in World War II (Green Book Series). Washington, DC: Historical Division, Department of the Army, 1948 (reprinted 1991).

Partin, John W. "Wars and New Challenges, 1939-1983." In Partin, John W., ed., A brief history of Fort Leavenworth. Fort Leavenworth, KS: Combat Studies Institute, United States Army Command and General Staff College, 1983.

Phillips, Neville C. 1957. Official history of New Zealand in the Second World War 1939-45. Italy Volume I: The Sangro to Cassino. Wellington, New Zealand: War History Branch, Department of Internal Affairs. Distributed by Christchurch, New Zealand: Whitcombe \& Tombs, Ltd.

Pimlott, John. 2006. The atlas of World War II. Philadelphia: Running Press.

Rohlfs, Chris. "Three Essays Measuring Dollar-Fatality Tradeoffs and Other Human Costs of War.” Ph.D. Dissertation, University of Chicago. June 2006b.

Rotte, Ralph and Schmidt, Christoph M. "On the Production of Victory: Empirical Determinants of Battlefield Success in Modern War." Defence and Peace Economics, June 2003, 14(3), pp. $175-92$.

Ruppenthal, Roland G. Logistical support of the armies. Volume 2. United States Army in World War II (Green Book Series). Washington, DC: Historical Division, Department of the Army, 1959.

Smith, R. Elberton. The Army and economic mobilization. United States Army in World War II (Green Book Series). Washington, DC: Historical Division, Department of the Army, 1959.

Stanton, Shelby L. Order of battle: U.S. Army, World War II. Novato, CA: Presidio Press, 1984.

Stone, Bill. 1999. "Free French Divisions." Available at: http://stonebooks.com/history/freefrench.shtml, most recently accessed on March 5, 2010.

Terry, Nick and Lowry Cole. 2001a. German Army, 1939-1945, volume 6: Divisions (Part 1). Milton Keynes, United Kingdom: Military Press. 
Terry, Nick and Lowry Cole. 2001b. German Army, 1939-1945, volume 7: Divisions (Part 2). Milton Keynes, United Kingdom: Military Press.

United States Airborne in World War II, The. "The U.S. Airborne in World War II." Roll of Honor lists of fatalities by division and regiment. Accessed on January $27^{\text {th }}, 2010$. Available at: http://www.ww2-airborne.us/division/order battle.html

U.S. American Battle Monuments Commission. 2005. "ABMC World War II Cemetery Files." Available as a searchable database at: http://www.abmc.gov/search/wwii.php. Contact: Martha Sell, ABMC. (703) 696-6897.

U.S. American Graves Registration Service. 1954. "Rosters of Military Personnel Whose Remains Were Not Recovered, 1951-54.” Record Group 92, Archives II. Contacts: John Horn, DPMO, John.Horn@osd.mil.

Available in electronic form at: http://www.dtic.mil/dpmo/WWII_MIA/INDEX.HTM

United States. Army Adjutant General. "Army Battle Casualties and Nonbattle Deaths in World War II: Final Report, 7 December 1941-31 December 1946.” Statistical and Accounting Branch, 1953. Library Call No. 1954:4728, National Archives II Building, College Park, MD.

United States. Army Air Forces. Army Air Forces statistical digest of World War II. Washington, DC: Office of Statistical Control, 1945.

United States. Army Chief of Staff. "Enlisted Men Used in Restricted Activities." Security Classified General Correspondence, 1944-45: 200, Case I, 1945a. Record Group 165, Entry 13, Box 150. National Archives II Building, College Park, MD.

United States. Army Chief of Staff. "Estimated Army Ground Forces Zone of the Interior Requirements." Security Classified General Correspondence, 1944-45: 200.3, Cases 32-75, 1945b. Record Group 165, Entry 13, Box 151. National Archives II Building, College Park, MD.

United States. Army Chief of Staff. "Quarterly Estimates of Personnel to Operate the Zone of the Interior Establishment." Security Classified General Correspondence, 1944-45: 200.3, Cases 32-75, 1945c. Record Group 165, Entry 13, Box 151. National Archives II Building, College Park, MD.

United States. Army Chief of Staff. "Summary of War Department Manpower Board Survey of Army Ground Forces Schools." Security Classified General Correspondence, 1944-45: 200.3, Case 75, 1945d. Record Group 165, Entry 13, Box 151. National Archives II Building, College Park, MD.

United States. Army European Theater of Operations (ETO). 1945. Order of battle of the United States Army World War II European Theater of Operations. Office of the Theater Historian, Paris France. 
Available at: http://www.history.army.mil/documents/eto-ob/ETOOB-TOC.htm

United States. Army Ground Forces. "Incidental Expenses of the Army, 440 - Ground Force Activities." Headquarters, Army War College, circa 1945. Record Group 337, Entry 51, Box 2. National Archives II Building, College Park, MD.

United States. Army Ground Forces. "Monthly Report of Lend-Lease Charges for Chinese Officers Training Program." Chief of Finance, May 1947. Record Group 337, Entry 51, Box 11, National Archives II Building, College Park, MD.

United States. Army Historical Services Division. "Statistics - Combat Days WWII." United States Army Center of Military History, 1962. Center of Military History Library Call No. HRC 052228.03 .

United States. Army Office of the Comptroller. "Estimated Annual Per Capita Cost of Enlisted Personnel, by Grade." Public Relations and Affairs Division, 1953. Center of Military History Library Call No. Misc. 121.6. Note: Contained in miscellaneous cost folder.

United States. Army Service Forces. "Army Supply Program: Section 1: Equipment, Ground." Statistical Unit, April 6, 1942a (Box 704); September 1, 1942b (Box 704); August 1, 1943a (Extract of Engineer Corps, Box 704); August 1, 1943b. (Box 705); February 1, 1943c (Extract of Engineer Corps, Box 704); February 1, 1944a (Box 706). Record Group 160, Entry 94. National Archives II Building, College Park, MD.

United States. Army Service Forces. "A.S.F. Logistical Planning and Reference Data." Planning Division, General Staff Corps, July 1943d. Record Group 160, Entry 94, Box 686. National Archives II Building, College Park, MD.

United States. Army Service Forces. "Data on Cost of Equipping and Maintaining a Soldier for One Year." Budgetary Control Sub-Section, Procurement Section, Clothing and Equipage Branch, Supply Division, Office of the Quartermaster General, 1944b. Center of Military History Library Call No. HRC 121.6.

United States. Army Service Forces. "Replacement Factors." Requirements Division, December 15, 1943e; June 15, 1944c and December 15, 1944d. Record Group 160, Entry 94, Box 699. National Archives II Building, College Park, MD.

United States. Army Service Forces. "Statistical Review, World War II: A Summary of ASF Activities." Statistics Branch, Control Division, circa 1954. Record Group 160, Entry 94, Box 702. National Archives II Building, College Park, MD.

United States. Army Service Forces Office of the Quartermaster General. Data on Cost of Equipping and Maintaining a Soldier for One Year. Budgetary Control Sub-Section, Procurement Section, Clothing and Equipage Branch, Supply Division, Office of The Quartermaster General, Army Service Forces, War Department. Washington, DC. 1944. CMH Library Call Number HRC 121.6. 
United States. Army Services of Supply. "Monthly Status Report Number, Equipment Section, Army Supply Program." Statistics and Progress Branch, Control Division, August 1942a and October 1942b. Record Group 160, Entry 94, Box 710. National Archives II Building, College Park, MD.

United States. Army Services of Supply. "Contributions of the Services of Supply to an Armored, a Motorized, and an Infantry Division of the Army of the U.S." Statistics and Progress Branch, Control Division, 1943. Record Group 160, Entry 94, Box 716, National Archives II Building, College Park, MD.

United States. Bureau of the Budget. The budget of the United States government. Washington, DC: United States Government Printing Office, 1940 to 1947.

United States. Bureau of Labor Statistics. "Prices of Specific Items," Consumer Price Index Statistics, 2004. <http://www.bls.gov/cpi/\#data>

United States. Bureau of Labor Statistics. "Consumer Price Index, All Urban Consumers (CPI U),” 2010. <ftp://ftp.bls.gov/pub/special.requests/cpi/cpiai.txt>

United States. Congress. "An Act to Provide for the Payment of Six Months' Pay to the Widow, Children, or Other Designated Dependent Relative of any Officer or Enlisted Man of the Regular Army whose Death Results from Wounds or Disease not the Result of his Own Misconduct." Statutes at Large, $66^{\text {th }}$ Congress, $2^{\text {nd }}$ Session. Chapter 6, 41 Statute 367, December 17, 1919.

United States. Congress. "National Defense Act Amendments." Statutes at Large, $66^{\text {th }}$ Congress, $2^{\text {nd }}$ Session, Chapter 227, 41 Statute 733, 766, June 4, 1920.

United States. Congress. "Pay Readjustment Act of 1942." Statutes at Large, $77^{\text {th }}$ Congress, $2^{\text {nd }}$ Session. Chapter 413, 56 Statute 359, June 16, 1942.

United States. Congress. "Amendment to the Pay Readjustment Act of 1942." Statutes at Large, $79^{\text {th }}$ Congress, $2^{\text {nd }}$ Session. Chapter 523, 60 Statute 343, June 29, 1946.

United States. Defense Finance and Accounting Service. "Military Pay Prior Rates," 2006. $<$ http://www.dod.mil/dfas/militarypay/2006militarypaytables/militarypay priorrates.html>

U.S. Geological Survey. 2005. "Shuttle Radar Topography Mission (SRTM) 'Finished' 3 Arc Second ( 90 Meter).” Available at: http://seamless.usgs.gov/products/srtm3arc.php\#download

U.S. National Archives and Records Administration. 2002. "Electronic Army Serial Number Merged File, ca. 1938-1946 (Enlistment Records)." Office of Records Services, Electronic and Special Media Records Division. Series from Record Group 64. Available as a searchable database at: $\mathrm{http}: / /$ aad.archives.gov/aad/fielded-search.jsp? $\mathrm{dt}=893 \& \mathrm{cat}=\mathrm{WR} 26 \& \mathrm{tf}=\mathrm{F} \& \mathrm{bc}={ }_{, \mathrm{s}} \mathrm{l}$. Contact: Lee Gladwin, NARA, (301) 837-0470. 
United States. National Geospatial-Intelligence Agency. "GEONet Names Server (GNS)," 2006. < http://earth-info.nga.mil/gns/html/gis_contryfiles.html $>$

U.S. Navy 1946. "State Summaries of War Casualties from World War II for Navy, Marine Corps, and Coast Guard Personnel." Office of Public Information, Casualty Section, Bureau of Naval Personnel. Record Group 24, Archives II. Contact: Mike Conley, ABMC. (703) 6966778.

Available in pdf format at: http://www.archives.gov/research/arc/ww2/navycasualties/index.html and as a searchable database at: http://www.wwiimemorial.com/default.asp?page=registry.asp

U.S. War Department. 1944. "Listing of All Battle Casualties, Officers and Enlisted Men by State, County, and Type of Casualty as Reported to Machine Records Branch - Books I to V (From 7 Dec. 1941 through 31 Dec. 1943)." Machine Records Branch, Adjutant General's Office. Tabulation No. CFN-8. Record Group 407.2.4, Archives II.

U.S. War Department. 1946. "World War II Honor List of Dead and Missing Army and Army Air Forces Personnel." Strength Accounting Branch, Administrative Services Division, Adjutant General's Office. Record Group 407.2.4, Archives II. Contact: Mike Conley, ABMC. (703) 696-6778.

Available in pdf format at: http://www.archives.gov/research/arc/ww2/army-casualties/ and as a searchable database at: http://www.wwiimemorial.com/default.asp?page=registry.asp

U.S. War Department. 1947. "Chemical Warfare Service Personnel Who Died During World War II 7 December 1941 Through 30 June 1946." Statistics and Reports Section, Strength Accounting Branch, Adjutant General's Office. Tabulation No. CFN-140. Record Group 407.2.4, Archives II. Note: These records are filed as deaths of Chemical Warfare Service personnel (Tabulation No. CFN-140). However, the folders include many other casualty lists (with different tabulation numbers) that are labeled in the files as alphabetical listings of battle deaths for each division.

United States. War Department Bureau of the Budget. "Estimated Cost of H.R. 5041, Armed Forces Leave Act of 1946." Special Staff, Budget Division, General Records, 1946. Record Group 165, Entry 455, Box 23. Security Classified General Correspondence, 1942-1947. Decimal 0.32.1. National Archives II Building, College Park, MD.

United States. War Department Office of the Budget Officer. "Additions to Revised Estimates, Fiscal Year 1943,” 1943. Record Group 337, Entry 51, Box 2, File No. SPBFO 3020. National Archives II Building, College Park, MD.

United States. War Department Public Relations Division. "Cost of Equipping, Maintaining Soldier for One Year Rises 10.7 Percent Since 1945.” Press Section, 1946. Center of Military History Library Call No. Misc. 121.6.

Von Luck, Hans. 1989. Panzer commander: the memoirs of Colonel Hans von Luck. New York: Dell Publishing. 
Von Mellenthin, F.W. 1956. Panzer battles. Old Saybrook, CT: Konecky \& Konecky.

Wikipedia, 2010a. "Military History of Australia During World War II."

http://en.wikipedia.org/wiki/Military_history_of_Australia_during_World_War_II, most recently accessed on March 5, 2010.

Wikipedia, 2010b. "Military History of Canada During World War II."

http://en.wikipedia.org/wiki/Military_history_of_Canada_during the Second_World_War, most recently accessed on March 5, 2010.

Wikipedia, 2010c. "Military History of France During World War II."

http://en.wikipedia.org/wiki/Military_history_of_France_during_World_War_II, most recently accessed on March 5, 2010.

Wikipedia, 2010d. "Military History of New Zealand During World War II." http://en.wikipedia.org/wiki/Military history of New_Zealand during_World War_II, most recently accessed on March 5, 2010.

Wilson, John B. Maneuver and firepower. United States Army Center of Military History. Washington, DC: United States Government Printing Office, 1998.

Zetterling, Niklas. 2000. Normandy, 1944: German military organization, combat power, and organizational effectiveness. Winnipeg, Canada: J.J. Fedorowicz Publishing, Inc. 
Figure A1: Estimated Costs, Fatalities, and Military Production Isoquants by Division Type, Estimates from Corps-Level Regressions

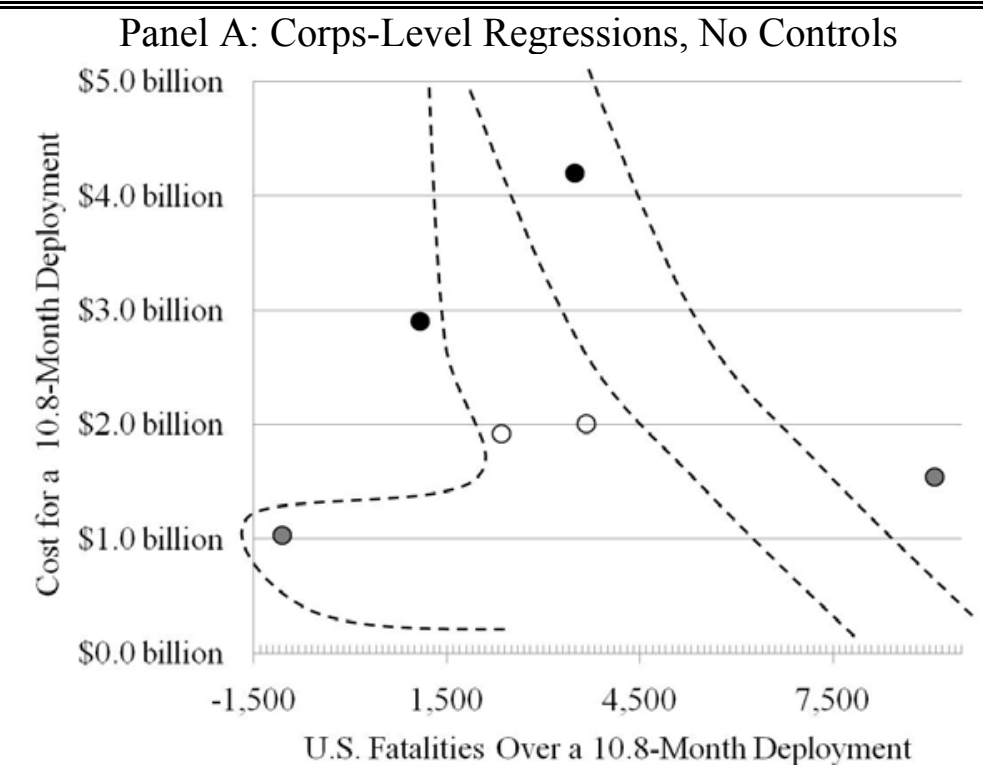

Panel B: Corps-Level Regressions with Controls

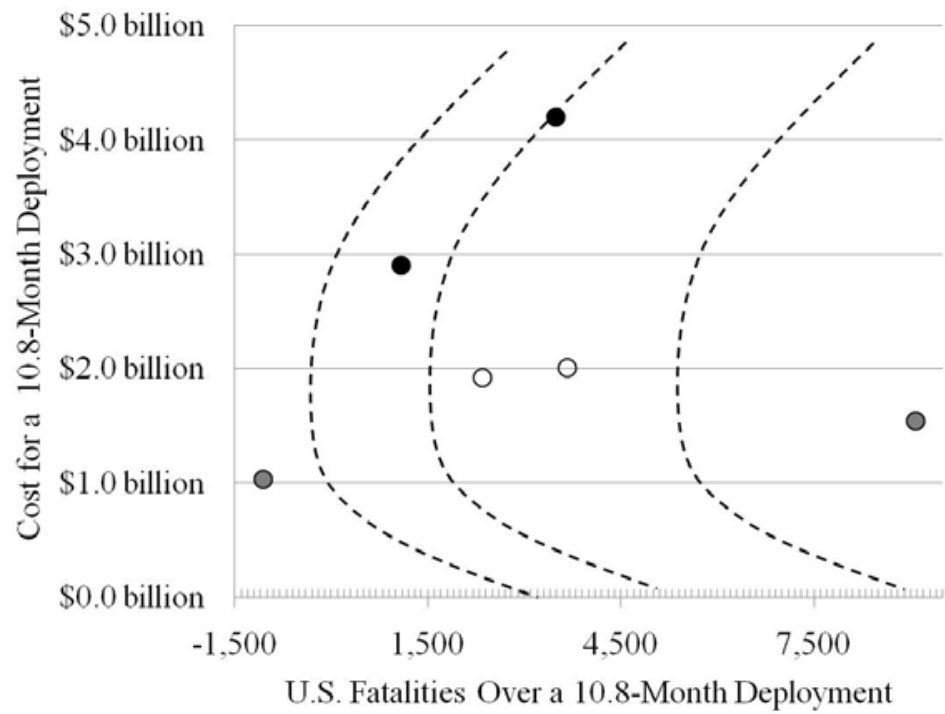

Notes to Figure A1: These figures are the corps-level counterparts to those shown in Figure 3. The fatality and $\mathrm{km}$ figures are the coefficients on the number of divisions of that type in each corps that day. Sample includes corps days in which one or more Axis divisions were in same the cell as the average division in that corps. Additional details in the text. 
Engagement name:

Engagement date:

Assessment date:

Assessor's Initials:

\section{Attacker}

\section{Defender}

Unit:

Unit:

Conceptual Accomplishment:

0 Conceptual Accomplishment

0

1

Geographical Accomplishment: $0 \quad$ Geographical Accomplishment: 0 1 2

Block Hostile Missions: $\quad 0 \quad$ Block Hostile Mission: 0

$\begin{array}{ll}1 & 1 \\ 2 & 2\end{array}$

Command \& Staff Performance: $0 \quad$ Command \& Staff Performance: 0

$1+1$

Troop Performance:

0 Troop Performance:

0

1

2

1

Bonus or Penalty:

Explain:

Bonus or Penalty:

Explain:

Total Score:

Total Score:

Notes to Figure A2: The 0-1 index of U.S. Mission Accomplishment used in this study is calculated as the (U.S. Total Score - German Total Score)/16. Source: The Dupuy Institute (2001a). 
Figure A3: Numbers of Troops and Tanks in an Organic U.S. Army Armored, Infantry, and Airborne Division, 1940-1945

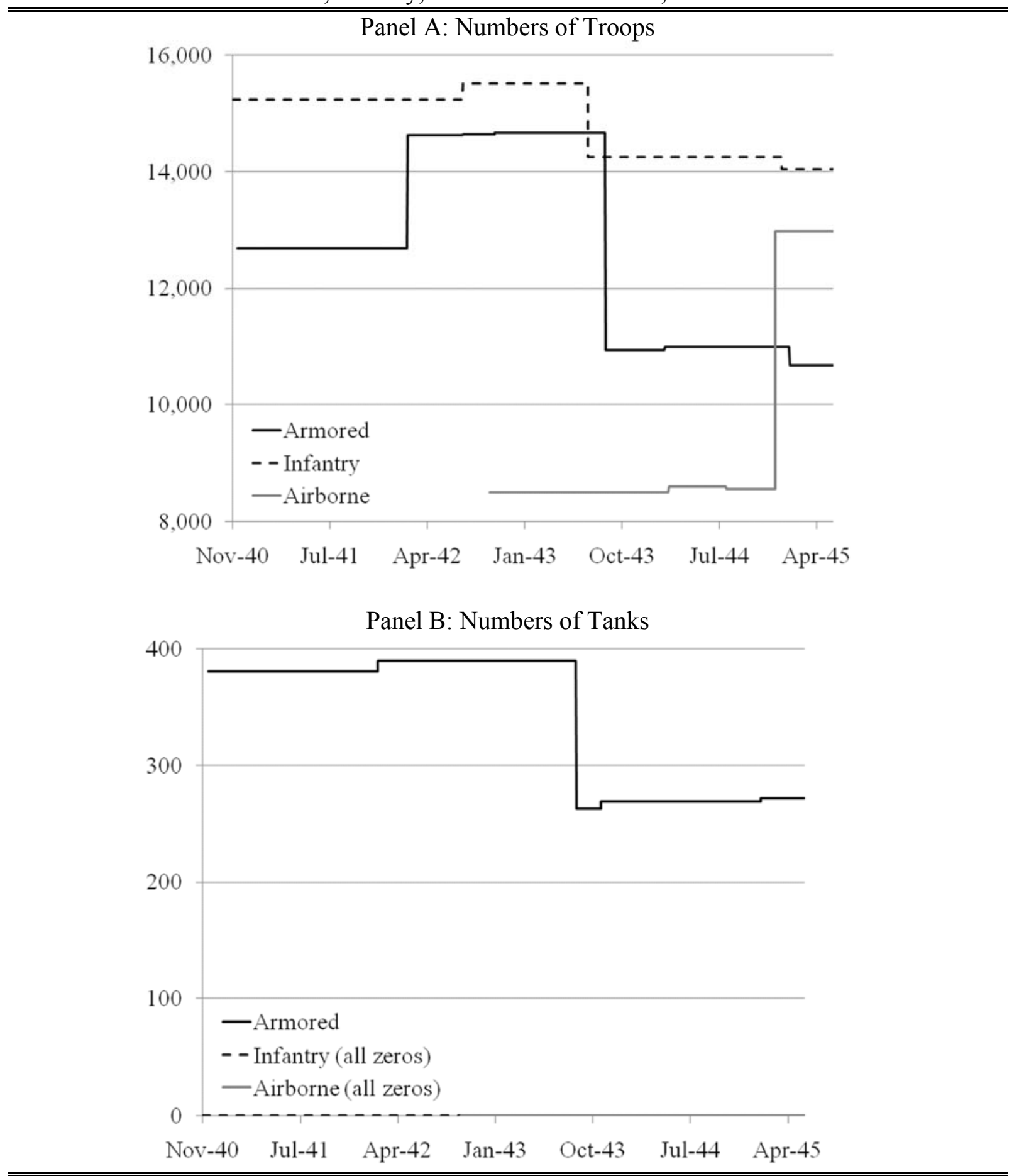

Notes to Figure A3: "Organic" indicates the numbers specified in the U.S. Army Tables of Organization and Equipment and ignores attached or detached battalions, combat losses, and replacement troops. Sources: Hays (2002, 2003a, 2003b, 2004). 
Table A3: Estimated Combat Outcomes and Costs Over a 10.8-Month Deployment by Division Type

\begin{tabular}{|c|c|c|c|c|c|c|c|c|c|}
\hline \multirow{3}{*}{\multicolumn{2}{|c|}{ Division Type and Variable }} & (1) & (2) & (3) & (4) & (5) & (6) & (7) & (8) \\
\hline & & \multicolumn{4}{|c|}{ Division by Day Panel } & \multicolumn{4}{|c|}{ Engagement Data } \\
\hline & & \multicolumn{2}{|c|}{$\begin{array}{l}\text { Axis Divisions } \\
\text { in Cell } \geq 1\end{array}$} & \multicolumn{2}{|c|}{ U.S. KIA $\geq 5$} & \multicolumn{2}{|c|}{ By Division Type } & \multicolumn{2}{|c|}{$\begin{array}{c}\text { Troop \& Tank } \\
\text { Regressions }\end{array}$} \\
\hline \multicolumn{10}{|c|}{ Pre-Reorganization } \\
\hline \multicolumn{10}{|c|}{ Armored Division } \\
\hline 1. & Km Advanced & 1.929 & 1.802 & 3.384 & 2.964 & 0.978 & 1.146 & 1.994 & 2.089 \\
\hline 2. & Mission Success & & & & & 0.764 & 0.699 & 0.692 & 0.626 \\
\hline 3. & U.S. Deaths & 1,059 & 834.0 & 1,346 & 1,255 & 2,297 & -500.7 & 2,624 & 561.4 \\
\hline 4. & Cost (billions) & $\$ 4.20$ & $\$ 4.20$ & $\$ 4.20$ & $\$ 4.20$ & $\$ 5.14$ & $\$ 5.14$ & $\$ 4.20$ & $\$ 4.20$ \\
\hline \multicolumn{10}{|c|}{ Infantry Division } \\
\hline 5. & Km Advanced & 1.058 & 0.768 & 1.513 & 2.946 & 0.587 & 0.436 & 0.572 & 0.596 \\
\hline 6. & Mission Success & & & & & 0.510 & 0.607 & 0.520 & 0.547 \\
\hline 7. & U.S. Deaths & 2,120 & 1,692 & 1,796 & 1,581 & 1,453 & 3,543 & 1,640 & 2,294 \\
\hline 8. & Cost (billions) & $\$ 1.92$ & $\$ 1.92$ & $\$ 1.92$ & $\$ 1.92$ & $\$ 2.20$ & $\$ 2.20$ & $\$ 1.92$ & $\$ 1.92$ \\
\hline \multicolumn{10}{|c|}{ Airborne Division } \\
\hline 9. & Km Advanced & 1.985 & 2.222 & -0.021 & 0.105 & & & 0.460 & 0.427 \\
\hline 10. & Mission Success & & & & & & & 0.489 & 0.448 \\
\hline 11. & U.S. Deaths & 3,948 & 2,935 & 2,302 & 1,982 & & & 1,436 & 2,024 \\
\hline 12. & Cost (billions) & $\$ 1.03$ & $\$ 1.03$ & $\$ 1.03$ & $\$ 1.03$ & & & $\$ 1.03$ & $\$ 1.03$ \\
\hline \multicolumn{10}{|c|}{ Post-Reorganization } \\
\hline \multicolumn{10}{|c|}{ Armored Division } \\
\hline 13. & Km Advanced & 1.706 & 1.931 & 3.699 & 3.407 & 1.923 & 2.980 & 1.758 & 2.073 \\
\hline 14. & Mission Success & & & & & 0.569 & 0.573 & 0.648 & 0.572 \\
\hline 15. & U.S. Deaths & 1,116 & 1,326 & 1,225 & 1,160 & 2,311 & $-1,011$ & 2,266 & 768 \\
\hline 16. & Cost (billions) & $\$ 2.90$ & $\$ 2.90$ & $\$ 2.90$ & $\$ 2.90$ & $\$ 2.93$ & $\$ 2.93$ & $\$ 2.90$ & $\$ 2.90$ \\
\hline \multicolumn{10}{|c|}{ Infantry Division } \\
\hline 17. & Km Advanced & 1.072 & 1.086 & 1.848 & 1.720 & 1.228 & 1.116 & 0.656 & 0.683 \\
\hline 18. & Mission Success & & & & & 0.590 & 0.481 & 0.529 & 0.544 \\
\hline 19. & U.S. Deaths & 1,822 & 1,904 & 1,839 & 1,901 & 1,967 & 613 & 1,685 & 2,157 \\
\hline 20. & Cost (billions) & $\$ 2.00$ & $\$ 2.00$ & $\$ 2.00$ & $\$ 2.00$ & $\$ 2.29$ & $\$ 2.29$ & $\$ 2.00$ & $\$ 2.00$ \\
\hline \multicolumn{10}{|c|}{ Airborne Division } \\
\hline 21. & Km Advanced & 1.574 & 1.472 & 0.874 & 1.764 & -2.090 & & 0.579 & 0.598 \\
\hline 22. & Mission Success & & & & & 0.613 & & 0.512 & 0.501 \\
\hline 23. & U.S. Deaths & 2,284 & 1,837 & 2,352 & 1,950 & 4,513 & & 1,570 & 2,091 \\
\hline 24. & Cost (billions) & $\$ 1.54$ & $\$ 1.54$ & $\$ 1.54$ & $\$ 1.54$ & $\$ 2.49$ & $\$ 2.49$ & $\$ 1.54$ & $\$ 1.54$ \\
\hline & ontrols? & & Yes & & Yes & & Yes & & Yes \\
\hline
\end{tabular}

Notes to Table A3: Estimates are the same as those presented in graphical form in the main text. 
Table A4: Cost per Life Saved and Lives Saved from Effectiveness-Neutral Combinations of Policies

\begin{tabular}{|c|c|c|c|c|c|c|c|c|}
\hline \multirow[b]{3}{*}{ Variable } & (1) & $(2)$ & (3) & (4) & (5) & $(6)$ & $(7)$ & (8) \\
\hline & \multicolumn{4}{|c|}{ Division by Day Panel } & \multicolumn{4}{|c|}{ Engagement Data } \\
\hline & \multicolumn{2}{|c|}{$\begin{array}{l}\text { Axis Divisions in Cell } \\
\geq 1\end{array}$} & \multicolumn{2}{|c|}{ U.S. KIA $\geq 5$} & \multicolumn{2}{|c|}{ By Division Type } & \multicolumn{2}{|c|}{$\begin{array}{l}\text { Troop \& Tank } \\
\text { Regressions }\end{array}$} \\
\hline \multicolumn{9}{|c|}{ Replace Infantry with Armored plus Partial Armored Reorganization } \\
\hline $\begin{array}{c}\text { Cost per Life Saved } \\
\text { (millions of } 2009 \text { dollars) }\end{array}$ & $\begin{array}{l}-\$ 3.328 \\
(22.58)\end{array}$ & $\begin{array}{c}\$ 2.643 \\
(1.212)^{* *}\end{array}$ & $\begin{array}{l}-\$ 37.26 \\
(324.2)\end{array}$ & $\begin{array}{l}\$ 7.224 \\
(18.19)\end{array}$ & $\begin{array}{l}-\$ 0.119 \\
(0.534)\end{array}$ & $\begin{array}{l}\$ 0.424 \\
(0.429)\end{array}$ & $\begin{array}{l}-\$ 10.21 \\
(24.69)\end{array}$ & $\begin{array}{l}\$ 0.394 \\
(0.900)\end{array}$ \\
\hline Lives Saved & $\begin{array}{c}837.1 \\
(1,015)\end{array}$ & $\begin{array}{c}4,807 \\
(26,666)\end{array}$ & $\begin{array}{l}-267.9 \\
(3,231)\end{array}$ & $\begin{array}{c}322.7 \\
(334.0)\end{array}$ & $\begin{array}{l}-577.5 \\
(907.8)\end{array}$ & $\begin{array}{c}3,030 \\
(805.6)\end{array}$ & $\begin{array}{c}271.2 \\
(653.7)\end{array}$ & $\begin{array}{c}966.4 \\
(565.4)^{*}\end{array}$ \\
\hline \multicolumn{9}{|c|}{ Infantry Reorganization plus Partial Replace Infantry with Armored } \\
\hline $\begin{array}{c}\text { Cost per Life Saved } \\
\text { (millions of } 2009 \text { dollars) }\end{array}$ & $\begin{array}{l}\$ 0.210 \\
(1.606)\end{array}$ & $\begin{array}{l}\$ 0.601 \\
(1.128)\end{array}$ & $\begin{array}{l}\$ 0.533 \\
(1.925)\end{array}$ & $\begin{array}{l}\$ 3.355 \\
(5.506)\end{array}$ & $\begin{array}{l}-\$ 2.072 \\
(4.356)\end{array}$ & $\begin{array}{c}\$ 0.262 \\
(0.099)^{* *}\end{array}$ & $\begin{array}{l}-\$ 6.832 \\
(80.72)\end{array}$ & $\begin{array}{c}\$ 0.927 \\
(0.493)^{*}\end{array}$ \\
\hline Lives Saved & $\begin{array}{c}281.4 \\
(475.9)\end{array}$ & $\begin{array}{l}-430.0 \\
(614.9)\end{array}$ & $\begin{array}{l}-154.0 \\
(332.5)\end{array}$ & $\begin{array}{c}218.2 \\
(516.1)\end{array}$ & $\begin{array}{l}-1,217 \\
(2,536)\end{array}$ & $\begin{array}{c}3,538.2 \\
(1,154)^{* *}\end{array}$ & $\begin{array}{l}-2.371 \\
(27.97)\end{array}$ & $\begin{array}{c}206.4 \\
(319.5)\end{array}$ \\
\hline \multicolumn{9}{|c|}{ Replace Infantry with Airborne plus Partial Airborne Reorganization } \\
\hline $\begin{array}{c}\text { Cost per Life Saved } \\
\text { (millions of } 2009 \text { dollars) }\end{array}$ & $\begin{array}{l}\$ 0.134 \\
(0.631)\end{array}$ & $\begin{array}{l}\$ 0.109 \\
(0.811)\end{array}$ & $\begin{array}{l}\$ 0.029 \\
(2.305)\end{array}$ & $\begin{array}{l}\$ 0.053 \\
(2.107)\end{array}$ & & & $\begin{array}{r}-\$ 15.13 \\
(138.7)\end{array}$ & $\begin{array}{l}\$ 0.631 \\
(0.452)\end{array}$ \\
\hline Lives Saved & $\begin{array}{c}1,930 \\
(8,069)\end{array}$ & $\begin{array}{c}885.7 \\
(2,561)\end{array}$ & $\begin{array}{l}-592.7 \\
(558.6)\end{array}$ & $\begin{array}{l}-346.2 \\
(506.1)\end{array}$ & & & $\begin{array}{c}12.15 \\
(111.4)\end{array}$ & $\begin{array}{c}98.58 \\
(53.46)^{*}\end{array}$ \\
\hline \multicolumn{9}{|c|}{ Infantry Reorganization plus Replace Infantry with Airborne } \\
\hline $\begin{array}{c}\text { Cost per Life Saved } \\
\text { (millions of } 2009 \text { dollars) }\end{array}$ & $\begin{array}{l}\$ 0.300 \\
(0.787)\end{array}$ & $\begin{array}{l}-\$ 1.720 \\
(5.878)\end{array}$ & $\begin{array}{l}\$ 0.357 \\
(1.229)\end{array}$ & $\begin{array}{l}\$ 7.608 \\
(38.69)\end{array}$ & $\begin{array}{l}-\$ 0.110 \\
(0.062)^{*}\end{array}$ & & $\begin{array}{l}-\$ 18.79 \\
(260.2)\end{array}$ & $\begin{array}{c}\$ 1.359 \\
(0.775)^{*}\end{array}$ \\
\hline $\begin{array}{c}\text { Lives Saved } \\
\text { (millions of } 2009 \text { dollars) }\end{array}$ & $\begin{array}{c}351.0 \\
(1,423)\end{array}$ & $\begin{array}{c}815.2 \\
(3,073)\end{array}$ & $\begin{array}{l}-216.8 \\
(515.6)\end{array}$ & $\begin{array}{c}-11,284 \\
(171,851)\end{array}$ & $\begin{array}{c}5,745 \\
(9,467)\end{array}$ & & $\begin{array}{c}7.796 \\
(108.3)\end{array}$ & $\begin{array}{c}86.86 \\
(47.13)^{*}\end{array}$ \\
\hline \multicolumn{9}{|c|}{ Replace Airborne with Armored plus Partial Armored Reorganization } \\
\hline $\begin{array}{c}\text { Cost per Life Saved } \\
\text { (millions of } 2009 \text { dollars) }\end{array}$ & $\begin{array}{l}\$ 1.201 \\
(2.127)\end{array}$ & $\begin{array}{l}-\$ 2.144 \\
(88.25)\end{array}$ & $\begin{array}{l}-\$ 48.99 \\
(632.6)\end{array}$ & $\begin{array}{l}\$ 96.79 \\
(2,150)\end{array}$ & & & $\begin{array}{l}-\$ 9.203 \\
(18.14)\end{array}$ & $\begin{array}{l}-\$ 1.964 \\
(2.629)\end{array}$ \\
\hline $\begin{array}{c}\text { Lives Saved } \\
\text { (millions of } 2009 \text { dollars) }\end{array}$ & $\begin{array}{c}2,904 \\
(285.3)^{* *}\end{array}$ & $\begin{array}{c}497.8 \\
(9,256)\end{array}$ & $\begin{array}{l}-350.9 \\
(5,738)\end{array}$ & $\begin{array}{c}119.4 \\
(2,395)\end{array}$ & & & $\begin{array}{c}304.3 \\
(594.1)\end{array}$ & $\begin{array}{c}563.7 \\
(514.7)\end{array}$ \\
\hline \multicolumn{9}{|c|}{ Airborne Reorganization plus Partial Replace Airborne with Armored } \\
\hline $\begin{array}{c}\text { Cost per Life Saved } \\
\text { (millions of } 2009 \text { dollars) }\end{array}$ & $\begin{array}{l}\$ 1.205 \\
(0.680)^{*}\end{array}$ & $\begin{array}{l}\$ 4.385 \\
(8.436)\end{array}$ & $\begin{array}{l}-\$ 0.197 \\
(3.849)\end{array}$ & $\begin{array}{l}\$ 0.772 \\
(1.374)\end{array}$ & & & $\begin{array}{l}-\$ 22.66 \\
(330.2)\end{array}$ & $\begin{array}{l}\$ 0.716 \\
(0.472)\end{array}$ \\
\hline Lives Saved & $\begin{array}{c}3,942 \\
(20,730)\end{array}$ & $\begin{array}{c}622.1 \\
(1,825)\end{array}$ & $\begin{array}{l}-400.1 \\
(1,104)\end{array}$ & $\begin{array}{l}-1,118 \\
(1,597)\end{array}$ & & & $\begin{array}{l}-12.51 \\
(182.3)\end{array}$ & $\begin{array}{l}-704.7 \\
(589.9)\end{array}$ \\
\hline Controls? & & Yes & & Yes & & Yes & & Yes \\
\hline
\end{tabular}

Notes to Table A4: Each cost per life saved estimates the cost of implementing one of the policies suggested plus partially implementing the second one the exact fraction of the amount necessary to hold success constant (measured as $\mathrm{km}$ success in the division by day data and the subjective index in the engagement data). Details in the text. 
Table A5: OLS and Fixed Effects Estimates of the First Stage Effects of Division Type on Kilometers of Progress and U.S. KIA, Division by Day Panel

\begin{tabular}{|c|c|c|c|c|c|c|c|c|c|c|}
\hline \multirow[b]{2}{*}{ Division Type } & (1) & (2) & (3) & (4) & (5) & (6) & (7) & (8) & (9) & (10) \\
\hline & \multicolumn{10}{|c|}{ Panel A: Dependent Variable is Kilometers of Progress Toward Berlin/Tunis/Messina } \\
\hline \multirow{4}{*}{$\begin{array}{l}\text { Post-Reorganization } \\
* \text { Armored }\end{array}$} & \multicolumn{5}{|c|}{ Division Days in Which Axis Divisions in Cell $\geq 1$} & \multicolumn{5}{|c|}{ Division Days in Which U.S. KIA $\geq 5$} \\
\hline & \multicolumn{3}{|c|}{ Full Sample } & & & \multicolumn{3}{|c|}{ Full Sample } & \multirow{3}{*}{$\begin{array}{c}22.41 \\
(10.13)^{* *}\end{array}$} & \multirow{3}{*}{$\begin{array}{c}1.281 \\
(15.03)\end{array}$} \\
\hline & -0.156 & 0.129 & 0.502 & -5.245 & -4.351 & 0.245 & 0.443 & 0.923 & & \\
\hline & $(0.658)$ & $(0.677)$ & $(0.743)$ & $(4.285)$ & $(4.257)$ & $(0.820)$ & $(0.834)$ & $(0.837)$ & & \\
\hline \multirow{2}{*}{$\begin{array}{l}\text { Post-Reorganization } \\
* \text { Infantry }\end{array}$} & 0.169 & 0.319 & 0.062 & -0.707 & -2.961 & -0.513 & -1.226 & 0.886 & 2.844 & \multirow{2}{*}{$\begin{array}{c}2.940 \\
(1.796)\end{array}$} \\
\hline & $(0.642)$ & $(0.693)$ & $(0.888)$ & $(0.987)$ & $(1.149)^{* *}$ & $(0.809)$ & $(0.894)$ & $(1.135)$ & $(1.410)^{* *}$ & \\
\hline \multirow{2}{*}{$\begin{array}{l}\text { Post-Reorganization } \\
\text { * Airborne }\end{array}$} & -0.273 & -0.751 & -0.654 & 13.58 & & 1.469 & 1.659 & 0.164 & -51.67 & \multirow{4}{*}{$\begin{array}{c}71.00 \\
(27.64)^{* *}\end{array}$} \\
\hline & $(1.849)$ & (1.986) & $(1.814)$ & (21.44) & & $(2.573)$ & $(2.688)$ & $(2.346)$ & (38.39) & \\
\hline \multirow[t]{2}{*}{ Armored } & 0.943 & 1.035 & 1.176 & -2.451 & & 0.968 & 0.018 & 0.499 & -1.112 & \\
\hline & $(0.762)$ & $(0.796)$ & $(1.061)$ & $(1.356)^{*}$ & & $(0.955)$ & $(1.005)$ & $(1.254)$ & (1.777) & \\
\hline \multirow[t]{2}{*}{ Airborne } & 1.065 & 1.455 & 1.286 & & & -2.536 & -2.841 & 1.802 & -34.75 & \\
\hline & (1.895) & $(2.044)$ & (1.923) & & & $(2.587)$ & $(2.723)$ & $(2.452)$ & $(27.20)$ & \\
\hline \multirow[t]{2}{*}{$\mathrm{R}^{2}$} & 0.003 & 0.025 & 0.357 & 0.649 & 0.657 & 0.007 & 0.031 & 0.579 & 0.773 & 0.773 \\
\hline & \multicolumn{10}{|c|}{ Panel B: Dependent Variable is U.S. Fatalities } \\
\hline Post-Reorganization & 5.914 & 7.333 & -2.505 & 20.05 & 19.03 & 2.255 & -1.357 & 1.500 & 11.88 & 21.59 \\
\hline * Armored & $(4.051)$ & $(4.087)^{*}$ & (4.948) & $(45.06)$ & $(45.27)$ & (2.369) & $(2.406)$ & (3.279) & (48.09) & $(71.21)$ \\
\hline Post-Reorganization & -0.424 & 3.160 & -26.61 & -23.58 & -30.29 & 7.736 & 4.617 & -9.011 & -1.246 & -2.957 \\
\hline * Infantry & (3.951) & (4.184) & $(5.917)^{* *}$ & $(10.38)^{* *}$ & $(12.21)^{* *}$ & $(2.336)^{* *}$ & $(2.578)^{*}$ & $(4.449)^{* *}$ & (6.695) & (8.510) \\
\hline Post-Reorganization & -29.80 & -16.37 & -14.39 & -14.82 & & -4.146 & -0.457 & -12.173 & 289.2 & 96.18 \\
\hline * Airborne & $(11.38)^{* *}$ & (11.99) & (12.08) & (225.4) & & (7.433) & (7.754) & (9.195) & (182.3) & \\
\hline Armored & -17.02 & -12.78 & -37.97 & -42.93 & & -2.197 & -4.707 & -18.043 & -9.918 & \\
\hline & $(4.689)^{* *}$ & $(4.810)^{* *}$ & $(7.068)^{* *}$ & $(14.26)^{* *}$ & & $(2.760)$ & (2.899) & $(4.916)^{* *}$ & (8.439) & \\
\hline Airborne & 30.44 & 18.52 & -4.466 & & & 15.77 & 5.773 & -2.426 & -79.12 & \\
\hline & $(11.66)^{* *}$ & $(12.35)$ & $(12.81)$ & & & $(7.472)^{* *}$ & $(7.854)$ & $(9.613)$ & $(129.1)$ & \\
\hline $\mathrm{R}^{2}$ & 0.054 & 0.108 & 0.285 & 0.466 & 0.467 & 0.038 & 0.070 & 0.248 & 0.335 & 0.340 \\
\hline Controls? & & Yes & Yes & Yes & Yes & & Yes & Yes & Yes & Yes \\
\hline Month \& Year Fes & & & Yes & Yes & Yes & & & Yes & Yes & Yes \\
\hline Axis Division Fes & & & Yes & Yes & Yes & & & Yes & Yes & Yes \\
\hline Cell Fes & & & Yes & Yes & Yes & & & Yes & Yes & Yes \\
\hline U.S. Division Fes & & & & & Yes & & & & & Yes \\
\hline N (Division Days) & & 4,430 & & & & & 4,579 & & & \\
\hline Clusters (Divisio & Ionths) & 470 & & & & & 516 & & & \\
\hline
\end{tabular}

Notes to Table A5: Within each panel, each column shows results from a different OLS or fixed effects regression. These regressions represent the first-stage estimates preceding the 2SLS estimates shown in Table 1 of the paper. Additional details in the text. 
Table A6: OLS Estimates of the First-Stage Effects of Division Type on Combat Outcomes, Engagement Data

$\begin{array}{lllllllllll}(1) & (2) & (3) & (4) & (5) & (6) & \text { (7) } & \text { (8) } & \text { (9) } & \text { (10) }\end{array}$

Dependent Variable is ...

\begin{tabular}{|c|c|c|c|c|c|c|c|c|c|c|c|c|}
\hline \multirow{2}{*}{$\begin{array}{l}\text { Variable } \\
\text { Post-Reorganiza- } \\
\text { tion * Armored }\end{array}$} & \multicolumn{2}{|c|}{$\begin{array}{l}\text { Km Progress } \\
\text { Along Axis of } \\
\text { Advance }\end{array}$} & \multicolumn{2}{|c|}{$\begin{array}{l}\text { Zero to One Index of } \\
\text { Mission Success }\end{array}$} & \multicolumn{2}{|c|}{$\begin{array}{c}\text { Indicator for U.S. } \\
\text { Success }(\text { Draw }=0.5)\end{array}$} & \multicolumn{2}{|c|}{ U.S. KIA } & \multicolumn{2}{|c|}{ U.S. Tank Losses } & \multicolumn{2}{|c|}{ German KIA } \\
\hline & $\begin{array}{c}0.426 \\
(1.160)\end{array}$ & $\begin{array}{c}1.852 \\
(2.129)\end{array}$ & $\begin{array}{c}-0.198 \\
(0.036)^{* *}\end{array}$ & $\begin{array}{l}-0.111 \\
(0.089)\end{array}$ & $\begin{array}{c}-0.209 \\
(0.096)^{* *}\end{array}$ & $\begin{array}{l}-0.140 \\
(0.323)\end{array}$ & $\begin{array}{c}4.294 \\
(12.01)\end{array}$ & $\begin{array}{l}-9.452 \\
(11.53)\end{array}$ & $\begin{array}{l}-4.918 \\
(7.850)\end{array}$ & $\begin{array}{c}-9.689 \\
(4.290)^{* *}\end{array}$ & $\begin{array}{c}4.935 \\
(24.65)\end{array}$ & $\begin{array}{l}-2.893 \\
(27.10)\end{array}$ \\
\hline $\begin{array}{l}\text { Post-Reorganiza- } \\
\text { tion * Infantry }\end{array}$ & $\begin{array}{l}-0.460 \\
(0.420)\end{array}$ & $\begin{array}{c}0.506 \\
(0.736)\end{array}$ & $\begin{array}{l}-0.023 \\
(0.071)\end{array}$ & $\begin{array}{c}-0.115 \\
(0.046)^{* *}\end{array}$ & $\begin{array}{c}0.114 \\
(0.163)\end{array}$ & $\begin{array}{l}-0.235 \\
(0.153)\end{array}$ & $\begin{array}{l}-7.083 \\
(7.373)\end{array}$ & $\begin{array}{c}-31.03 \\
(5.427)^{* *}\end{array}$ & $\begin{array}{c}3.346 \\
(2.949)\end{array}$ & $\begin{array}{c}0.979 \\
(3.589)\end{array}$ & $\begin{array}{l}-10.42 \\
(9.263)\end{array}$ & $\begin{array}{c}-20.99 \\
(12.61)^{*}\end{array}$ \\
\hline Armored & $\begin{array}{l}-0.821 \\
(1.027)\end{array}$ & $\begin{array}{c}0.562 \\
(1.402)\end{array}$ & $\begin{array}{c}0.133 \\
(0.072)^{*}\end{array}$ & $\begin{array}{c}0.087 \\
(0.085)\end{array}$ & $\begin{array}{c}0.299 \\
(0.170)^{*}\end{array}$ & $\begin{array}{c}0.186 \\
(0.320)\end{array}$ & $\begin{array}{l}-7.121 \\
(12.36)\end{array}$ & $\begin{array}{c}-33.37 \\
(10.53)^{* *}\end{array}$ & $\begin{array}{c}13.37 \\
(7.489) *\end{array}$ & $\begin{array}{c}14.85 \\
(4.828)^{* *}\end{array}$ & $\begin{array}{c}8.966 \\
(22.67)\end{array}$ & $\begin{array}{l}-13.68 \\
(22.62)\end{array}$ \\
\hline $\begin{array}{l}\text { Controls Include ... } \\
\text { Date \& Continent } \\
\text { Enemy Inputs } \\
\text { Terrain \& Weather } \\
\text { Human Factors }\end{array}$ & Yes & $\begin{array}{l}\text { Yes } \\
\text { Yes } \\
\text { Yes } \\
\text { Yes }\end{array}$ & Yes & $\begin{array}{l}\text { Yes } \\
\text { Yes } \\
\text { Yes } \\
\text { Yes }\end{array}$ & Yes & $\begin{array}{l}\text { Yes } \\
\text { Yes } \\
\text { Yes } \\
\text { Yes }\end{array}$ & Yes & $\begin{array}{l}\text { Yes } \\
\text { Yes } \\
\text { Yes } \\
\text { Yes }\end{array}$ & Yes & $\begin{array}{l}\text { Yes } \\
\text { Yes } \\
\text { Yes } \\
\text { Yes }\end{array}$ & Yes & $\begin{array}{l}\text { Yes } \\
\text { Yes } \\
\text { Yes } \\
\text { Yes }\end{array}$ \\
\hline $\begin{array}{l}\mathrm{R}^{2} \\
\mathrm{~N} \text { (Division Days) } \\
\text { Clusters (Engagements) }\end{array}$ & $\begin{array}{c}0.076 \\
279 \\
152\end{array}$ & $\begin{array}{l}0.453 \\
279 \\
152\end{array}$ & $\begin{array}{c}0.186 \\
279 \\
152\end{array}$ & $\begin{array}{l}0.597 \\
279 \\
152\end{array}$ & $\begin{array}{c}0.144 \\
279 \\
152\end{array}$ & $\begin{array}{c}0.514 \\
279 \\
152\end{array}$ & $\begin{array}{c}0.083 \\
279 \\
152\end{array}$ & $\begin{array}{c}0.531 \\
279 \\
152\end{array}$ & $\begin{array}{c}0.383 \\
215 \\
118\end{array}$ & $\begin{array}{c}0.649 \\
215 \\
118\end{array}$ & $\begin{array}{c}0.231 \\
279 \\
152\end{array}$ & $\begin{array}{c}0.482 \\
279 \\
152\end{array}$ \\
\hline
\end{tabular}

Notes to Table A6: Within each panel, each column shows results from a different OLS regression. The regressions in columns (1) to (4) (and scaled versions of the regressions in columns (7) and (8)) represent the first-stage estimates preceding the 2SLS estimates shown in the first few columns of Table 2 of the paper.

Additional details in the text. 
Table A7: OLS and Fixed Effects Estimates of the First Stage Effects of Troops and Tanks, Engagement Data

\begin{tabular}{|c|c|c|c|c|c|c|}
\hline \multirow[b]{2}{*}{ Variable } & (1) & (2) & (3) & (4) & (5) & (6) \\
\hline & \multicolumn{6}{|c|}{ Panel A: Dependent Variable is Km of Progress } \\
\hline & \multicolumn{2}{|c|}{ Full Sample } & \multicolumn{4}{|c|}{ Fixed Effects Sample } \\
\hline U.S. Troops $/ 10,000$ & $\begin{array}{c}0.204 \\
(0.444)\end{array}$ & $\begin{array}{l}-0.010 \\
(0.568)\end{array}$ & $\begin{array}{l}-0.278 \\
(0.526)\end{array}$ & $\begin{array}{c}0.078 \\
(0.513)\end{array}$ & $\begin{array}{l}-0.208 \\
(0.724)\end{array}$ & $\begin{array}{l}-1.706 \\
(1.393)\end{array}$ \\
\hline U.S. Tanks/100 & $\begin{array}{c}0.714 \\
(0.688)\end{array}$ & $\begin{array}{c}1.169 \\
(0.800)\end{array}$ & $\begin{array}{c}1.688 \\
(1.246)\end{array}$ & $\begin{array}{c}2.065 \\
(1.550)\end{array}$ & $\begin{array}{c}2.093 \\
(1.126)^{*}\end{array}$ & $\begin{array}{c}1.338 \\
(1.408)\end{array}$ \\
\hline $\begin{array}{l}\text { U.S. Troops * U.S. } \\
\text { Tanks } / 1,000,000\end{array}$ & $\begin{array}{l}-0.231 \\
(0.232)\end{array}$ & $\begin{array}{l}-0.404 \\
(0.294)\end{array}$ & $\begin{array}{l}-0.503 \\
(0.413)\end{array}$ & $\begin{array}{l}-0.486 \\
(0.390)\end{array}$ & $\begin{array}{l}-0.602 \\
(0.374)\end{array}$ & $\begin{array}{l}-0.026 \\
(0.288)\end{array}$ \\
\hline $\mathrm{R}^{2}$ & \multicolumn{6}{|c|}{ Panel B: Dependent Variable is Zero to One Index of Mission Success } \\
\hline U.S. Troops $/ 10,000$ & $\begin{array}{c}0.033 \\
(0.032)\end{array}$ & $\begin{array}{c}0.127 \\
(0.046)^{* *}\end{array}$ & $\begin{array}{c}0.013 \\
(0.033)\end{array}$ & $\begin{array}{c}0.051 \\
(0.036)\end{array}$ & $\begin{array}{c}0.118 \\
(0.060)^{*}\end{array}$ & $\begin{array}{c}0.179 \\
(0.082)^{* *}\end{array}$ \\
\hline U.S. Tanks/100 & $\begin{array}{c}0.072 \\
(0.027)^{* *}\end{array}$ & $\begin{array}{c}0.085 \\
(0.037)^{* *}\end{array}$ & $\begin{array}{c}0.056 \\
(0.047)\end{array}$ & $\begin{array}{l}-0.070 \\
(0.060)\end{array}$ & $\begin{array}{c}0.085 \\
(0.062)\end{array}$ & $\begin{array}{l}-0.047 \\
(0.090)\end{array}$ \\
\hline $\begin{array}{l}\text { U.S. Troops * U.S. } \\
\text { Tanks } / 1,000,000\end{array}$ & $\begin{array}{c}-0.020 \\
(0.010)^{*}\end{array}$ & $\begin{array}{c}-0.032 \\
(0.014)^{* *}\end{array}$ & $\begin{array}{l}-0.013 \\
(0.015)\end{array}$ & $\begin{array}{c}0.015 \\
(0.017)\end{array}$ & $\begin{array}{l}-0.033 \\
(0.024)\end{array}$ & $\begin{array}{l}-0.009 \\
(0.030)\end{array}$ \\
\hline $\mathrm{R}^{2}$ & \multicolumn{6}{|c|}{ Panel C: Dependent Variable is U.S. KIA } \\
\hline U.S. Troops/10,000 & $\begin{array}{c}1.556 \\
(6.600)\end{array}$ & $\begin{array}{c}2.949 \\
(7.227)\end{array}$ & $\begin{array}{c}0.185 \\
(8.813)\end{array}$ & $\begin{array}{c}-15.09 \\
(5.741)^{* *}\end{array}$ & $\begin{array}{l}8.066 \\
(9.19)\end{array}$ & $\begin{array}{c}23.12 \\
(9.527)^{* *}\end{array}$ \\
\hline U.S. Tanks/100 & $\begin{array}{r}1.135 \\
(6.152)\end{array}$ & $\begin{array}{l}-5.324 \\
(5.925)\end{array}$ & $\begin{array}{c}13.39 \\
(10.48)\end{array}$ & $\begin{array}{c}19.94 \\
(13.54)\end{array}$ & $\begin{array}{r}7.833 \\
(7.883)\end{array}$ & $\begin{array}{l}-5.359 \\
(9.647)\end{array}$ \\
\hline $\begin{array}{l}\text { U.S. Troops * U.S. } \\
\text { Tanks/1,000,000 }\end{array}$ & $\begin{array}{l}-0.053 \\
(2.409)\end{array}$ & $\begin{array}{c}0.763 \\
(2.413)\end{array}$ & $\begin{array}{l}-3.832 \\
(3.596)\end{array}$ & $\begin{array}{l}-3.750 \\
(3.379)\end{array}$ & $\begin{array}{l}-4.198 \\
(3.046)\end{array}$ & $\begin{array}{l}-3.388 \\
(2.794)\end{array}$ \\
\hline $\begin{array}{l}\mathrm{R}^{2} \\
\text { Controls Include ... }\end{array}$ & 0.077 & 0.436 & 0.105 & 0.386 & 0.509 & 0.638 \\
\hline $\begin{array}{l}\text { Date \& Continent } \\
\text { Enemy Inputs } \\
\text { Terrain \& Weather } \\
\text { Human Factors } \\
\text { Axis Division Fes }\end{array}$ & Yes & $\begin{array}{l}\text { Yes } \\
\text { Yes } \\
\text { Yes } \\
\text { Yes }\end{array}$ & Yes & Yes & $\begin{array}{l}\text { Yes } \\
\text { Yes } \\
\text { Yes } \\
\text { Yes }\end{array}$ & $\begin{array}{l}\text { Yes } \\
\text { Yes } \\
\text { Yes } \\
\text { Yes } \\
\text { Yes }\end{array}$ \\
\hline U.S. Division Fes & & & & Yes & & Yes \\
\hline $\begin{array}{l}\text { N (Division Days) } \\
\text { Clusters (Engagements) }\end{array}$ & $\begin{array}{l}289 \\
162 \\
\end{array}$ & $\begin{array}{l}289 \\
162 \\
\end{array}$ & $\begin{array}{l}225 \\
132 \\
\end{array}$ & $\begin{array}{l}225 \\
132 \\
\end{array}$ & $\begin{array}{l}225 \\
132 \\
\end{array}$ & $\begin{array}{l}225 \\
132 \\
\end{array}$ \\
\hline
\end{tabular}

Notes to Table A7: Within each panel, each column shows results from a different OLS or fixed effects regression. These regressions represent the first-stage estimates preceding the 2SLS estimates shown in the last few columns of Table 2 of the paper. Additional details in the text. 
Table A8: Corps by Day-Level 2SLS Estimates of the Cost Function for Military Operations, Collapsed Division by Day Panel

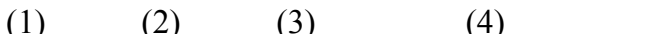

Dependent Variable is Estimated Dollar Cost per Day in Millions of 2009 Dollars

All Division Type Indicators are Excluded Instruments

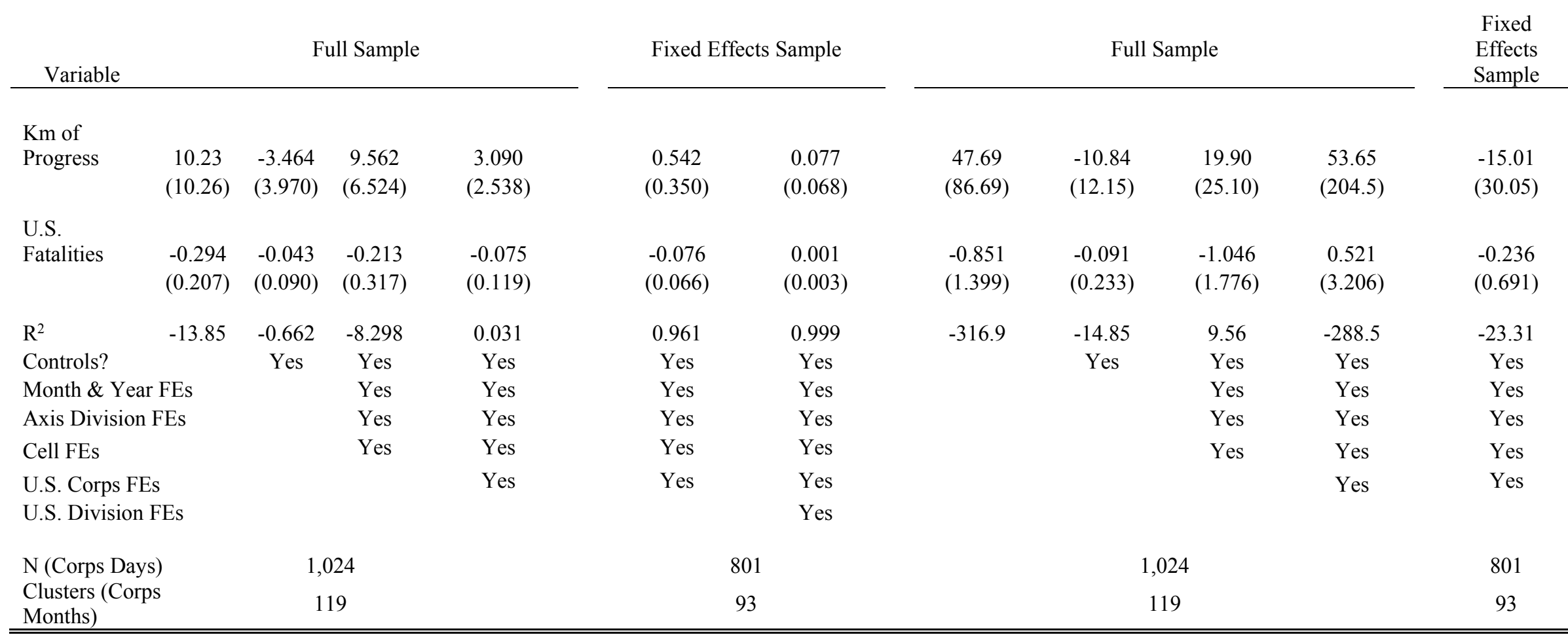

Notes to Table A8: Each column shows results from a different corps by day-level 2SLS regression. The specifications are the same as in Table 1, except that the data are organized at the corps by day level, the total number of divisions in the corps is a control variable, and the nearby Allied unit controls are replaced with controls for the other Allied units in the corps. Additional details in the text.

Armored and Airborne Indicators are Only Excluded Instruments

15.01

(30.05)

0.236

at

(1)


Table A9: 2SLS Estimates of the Cost Function for Military Operations with Alternative Clustering, Division by Day Panel

$\begin{array}{llllll}(1) & (2) & (3) & \text { (4) } & \text { (5) } & \text { (6) }\end{array}$

Dependent Variable is Estimated Dollar Cost per Day in Millions of 2009 Dollars

Panel A: Division Days in Which Axis Divisions in Cell $\geq 1$

\begin{tabular}{|c|c|c|c|c|c|}
\hline Full Sample & $\begin{array}{c}\text { Only } \\
\text { Armored } \\
\text { and Infantry }\end{array}$ & $\begin{array}{c}\text { Only } \\
\text { Infantry and } \\
\text { Airborne }\end{array}$ & $\begin{array}{l}\text { Only } \\
\text { Armored } \\
\text { and }\end{array}$ & $\begin{array}{c}\text { Only Pre- } \\
\text { Reorganization }\end{array}$ & $\begin{array}{c}\text { Only Post- } \\
\text { Reorganization }\end{array}$ \\
\hline
\end{tabular}

Variable

\begin{tabular}{|c|c|c|c|c|c|c|c|}
\hline Km of Progress & 2.093 & -0.288 & 8.408 & -15.06 & 8.207 & 0.423 & -27.69 \\
\hline (by division month) & $(12.20)$ & $(9.057)$ & $(9.157)$ & $(21.01)$ & $(10.50)$ & (4.939) & $(128.7)$ \\
\hline (by corps month) & (14.57) & $(10.91)$ & $(9.966)$ & (21.68) & (11.08) & $(5.667)$ & $(166.4)$ \\
\hline (by division) & $(14.48)$ & (9.913) & (8.119) & (13.13) & $(8.943)$ & $(4.143)$ & $(84.77)$ \\
\hline U.S. Fatalities & -1.436 & -1.926 & -1.428 & 0.048 & -1.475 & -1.637 & -4.371 \\
\hline (by division month) & $(0.583)^{* *}$ & $(0.625)^{* *}$ & $(0.768)^{*}$ & $(2.464)$ & $(0.615)^{* *}$ & $(0.576)^{* *}$ & $(12.31)$ \\
\hline (by corps month) & $(0.764)^{*}$ & $(0.856)^{* *}$ & $(0.854)^{*}$ & $(2.803)$ & $(0.668)^{* *}$ & $(0.600)^{* *}$ & $(15.98)$ \\
\hline (by division) & $(0.679) * *$ & $(0.631)^{* *}$ & $(0.637)^{* *}$ & $(1.661)$ & $(0.515)^{* *}$ & $(0.422)^{* *}$ & $(8.156)$ \\
\hline $\mathrm{R}^{2}$ & -71.78 & -114.1 & -110.9 & $-3,003$ & -65.24 & -13.28 & $-4,062$ \\
\hline N (Division Days) & \multicolumn{2}{|c|}{4,430} & 4,107 & 3,689 & 1,064 & 598 & 3,832 \\
\hline Corps Months & \multicolumn{2}{|c|}{226} & 204 & 215 & 136 & 54 & 204 \\
\hline \multirow[t]{2}{*}{ Divisions } & \multicolumn{2}{|c|}{63} & 60 & 47 & 19 & 10 & 61 \\
\hline & \multicolumn{7}{|c|}{ Panel B: Division Days in Which U.S. KIA $\geq 5$} \\
\hline Km of Progress & 6.955 & -18.58 & -80.49 & 7.891 & 33.66 & -0.846 & -22.39 \\
\hline (by division month) & $(7.509)$ & $(27.46)$ & $(338.1)$ & $(8.692)$ & $(94.89)$ & $(11.65)$ & $(95.47)$ \\
\hline (by corps month) & $(7.966)$ & $(27.94)$ & $(350.2)$ & $(8.688)$ & $(89.54)$ & $(11.61)$ & $(142.2)$ \\
\hline (by division) & $(7.952)$ & $(24.24)$ & $(290.3)$ & $(3.774)^{* *}$ & $(63.05)$ & (11.77) & $(89.81)$ \\
\hline U.S. Fatalities & -0.711 & -4.673 & -14.48 & -0.014 & 2.068 & -4.956 & -4.849 \\
\hline (by division month) & $(1.202)$ & $(4.587)$ & $(53.23)$ & $(1.141)$ & $(10.44)$ & $(5.268)$ & $(15.15)$ \\
\hline (by corps month) & (1.384) & $(4.712)$ & $(55.18)$ & $(1.348)$ & $(9.982)$ & $(5.416)$ & $(22.94)$ \\
\hline (by division) & $(1.256)$ & $(4.241)$ & $(46.88)$ & (1.094) & $(6.843)$ & $(3.995)$ & $(14.28)$ \\
\hline $\mathrm{R}^{2}$ & -80.23 & -766.6 & $-11,997$ & $-1,940$ & -981.4 & -42.24 & $-3,140$ \\
\hline Controls? & & Yes & Yes & Yes & Yes & Yes & Yes \\
\hline N (Division Days) & \multicolumn{2}{|c|}{4,579} & 4,395 & 3,841 & 922 & 621 & 3,958 \\
\hline Corps Months & \multicolumn{2}{|c|}{224} & 204 & 216 & 126 & 65 & 194 \\
\hline Divisions & \multicolumn{2}{|c|}{64} & 61 & 49 & 18 & 10 & 62 \\
\hline
\end{tabular}

Notes to Table A9: This table reproduces estimates from Table 1 but with varying ways of clustering the standard errors. Additional details in the text. 
Table A10: 2SLS Estimates of the Cost Function for Military Operations with Alternative Clustering, Engagement Data

\begin{tabular}{|c|c|c|c|c|c|c|c|c|}
\hline \multirow{2}{*}{ 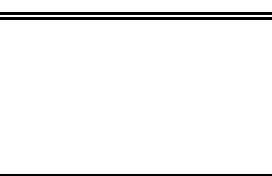 } & (1) & (2) & (3) & (4) & (6) & (8) & $(10)$ & (12) \\
\hline & \multicolumn{8}{|c|}{$\begin{array}{l}\text { Dependent Variable is Estimated Cost per Day in Millions of } 2009 \text { Dollars } \\
\text { Panel A: Mission Effectiveness Measured as Km Progress }\end{array}$} \\
\hline \multirow[b]{2}{*}{ Variable } & \multicolumn{4}{|c|}{$\begin{array}{l}\text { Excluded Instruments are Indicators for } \\
\text { Armored, Post-Reorganization*Infantry, } \\
\text { and Post-Reorganization*Armored }\end{array}$} & \multicolumn{4}{|c|}{$\begin{array}{l}\text { Excluded Instruments are U.S. Troops, } \\
\text { U.S. Tanks, and U.S. Troops * U.S. Tanks }\end{array}$} \\
\hline & \multicolumn{4}{|c|}{ Excluding Airborne } & $\begin{array}{c}\text { Full } \\
\text { Sample }\end{array}$ & $\begin{array}{c}\text { Low } \\
\text { Tank } \\
\text { Intensity }\end{array}$ & $\begin{array}{l}\text { High } \\
\text { Tank } \\
\text { Intensity }\end{array}$ & $\begin{array}{l}\text { Fixed } \\
\text { Effects } \\
\text { Sample }\end{array}$ \\
\hline Km of Progress & $-1,411$ & 558.1 & -721.6 & 21.73 & 48.58 & 279.6 & 1,051 & -961.2 \\
\hline (by engagement) & $(3,449)$ & $(594.2)$ & $(1,425)$ & (58.19) & $(1,220)$ & $(127.9)^{* *}$ & $(2,009)$ & $(2,265)$ \\
\hline (by division) & $(3,277)$ & (717.9) & $(1,248)$ & $(56.86)$ & $(992.0)$ & $(90.14)^{* *}$ & $(1,812)$ & $(2,611)$ \\
\hline U.S. Fatalities & 2.571 & -0.833 & -0.595 & -0.080 & 4.721 & 0.286 & 6.942 & 4.727 \\
\hline (by engagement) & (13.61) & $(1.414)$ & (1.833) & $(0.178)$ & (7.808) & $(1.006)$ & $(17.58)$ & (12.46) \\
\hline (by division) & $(11.54)$ & $(1.272)$ & $(2.512)$ & $(0.191)$ & $(9.280)$ & $(0.805)$ & $(12.41)$ & (14.79) \\
\hline $\mathrm{R}^{2}$ & -278.9 & -36.93 & -55.44 & 0.182 & -178.4 & -24.9 & -491.6 & -486.1 \\
\hline \multicolumn{9}{|c|}{ Panel B: Mission Effectiveness Measured with Zero to One Index } \\
\hline Zero to One & & & & & & & & \\
\hline Index & 2,995 & -760.4 & 2,296 & 4,053 & 578.0 & 5,487 & 7,194 & 13,757 \\
\hline (by engagement) & $(872.7)^{* *}$ & $(2,570)$ & $(925.9)^{* *}$ & $(1,562)^{* *}$ & $(13,561)$ & $(10,558)$ & $(4,246)^{*}$ & $(9,711)$ \\
\hline (by division) & $(1,045)^{* *}$ & $(3,366)$ & $(1,171)^{*}$ & $(1,259)^{* *}$ & $(11,275)$ & $(14,033)$ & $(4,489)$ & $(12,360)$ \\
\hline U.S. Fatalities & 0.422 & -1.270 & -0.309 & -0.142 & 4.506 & -1.468 & -0.035 & -1.505 \\
\hline (by engagement) & $(1.251)$ & $(1.696)$ & $(0.592)$ & $(0.379)$ & (12.12) & (4.114) & $(1.823)$ & (3.879) \\
\hline (by division) & $(1.458)$ & $(2.736)$ & $(0.763)$ & $(0.399)$ & $(12.40)$ & $(5.372)$ & $(1.634)$ & $(4.978)$ \\
\hline $\begin{array}{l}\text { Controls Include } \\
\text { Date \& } \\
\text { Continent }\end{array}$ & Yes & Yes & Yes & Yes & Yes & Yes & Yes & Yes \\
\hline Sorties \& Enemy I & nputs & Yes & & & & & & \\
\hline Terrain \& Weather & & & Yes & & & & & \\
\hline Human Factors & & & & Yes & & & & \\
\hline $\begin{array}{l}\mathrm{R}^{2} \\
\mathrm{~N} \text { (Division }\end{array}$ & -4.094 & -10.64 & -2.070 & -3.443 & -163.7 & -69.54 & -15.08 & -126.5 \\
\hline Days) & 279 & 279 & 279 & 279 & 289 & 150 & 139 & 225 \\
\hline Divisions & 19 & 19 & 19 & 19 & 20 & 13 & 16 & 15 \\
\hline
\end{tabular}

Notes to Table A10: This table reproduces estimates from Table 2 but with varying ways of clustering the standard errors. Additional details in the text. 
Table A11: 2SLS Estimates of the Cost Function for Military Operations with Alternative Specifications, Engagement Data

Excluded Instruments are Indicators for Armored, Post-Reorganization*Infantry, and Post-Reorganization*Armored

Excluded Instruments are U.S. Troops, U.S. Tanks, and U.S. Troops * U.S. Tanks

\begin{tabular}{|c|c|c|c|c|c|c|c|c|c|c|c|c|c|c|}
\hline Variable & \multicolumn{2}{|c|}{$\begin{array}{c}\text { Benchmark, } \\
\text { Excluding Airborne }\end{array}$} & \multicolumn{2}{|c|}{$\begin{array}{l}\text { Excluding Cases with } \\
\text { U.S. as Defender }\end{array}$} & \multicolumn{2}{|c|}{$\begin{array}{l}\text { Excluding Cases with } \\
\text { Axis Aerial Sorties }\end{array}$} & \multirow{2}{*}{$\begin{array}{c}\text { Light \& } \\
\text { Heavy } \\
\text { Tanks } \\
\text { Treated } \\
\text { Separately } \\
73.31 \\
(69.88)\end{array}$} & \multicolumn{2}{|c|}{$\begin{array}{l}\text { Benchmark, Full } \\
\text { Sample }\end{array}$} & \multicolumn{2}{|c|}{$\begin{array}{l}\text { Excluding Cases with } \\
\text { U.S. as Defender }\end{array}$} & \multicolumn{2}{|c|}{$\begin{array}{l}\text { Excluding Cases with } \\
\text { Axis Aerial Sorties }\end{array}$} & $\begin{array}{c}\text { Light \& } \\
\text { Heavy } \\
\text { Tanks } \\
\text { Treated } \\
\text { Separately }\end{array}$ \\
\hline $\begin{array}{l}\text { Km of } \\
\text { Progress }\end{array}$ & $\begin{array}{c}74.22 \\
(68.44)\end{array}$ & $\begin{array}{c}30.29 \\
(54.53)\end{array}$ & $\begin{array}{c}47.54 \\
(56.00)\end{array}$ & $\begin{array}{c}37.98 \\
(56.69)\end{array}$ & $\begin{array}{c}77.26 \\
(73.59)\end{array}$ & $\begin{array}{c}42.12 \\
(56.27)\end{array}$ & & $\begin{array}{l}-338.8 \\
(361.6)\end{array}$ & $\begin{array}{l}-492.9 \\
(547.5)\end{array}$ & $\begin{array}{l}-440.4 \\
(379.5)\end{array}$ & $\begin{array}{l}-807.6 \\
(1,037)\end{array}$ & $\begin{array}{l}-406.6 \\
(417.1)\end{array}$ & $\begin{array}{l}-1,591 \\
(4,208)\end{array}$ & $\begin{array}{l}-19.76 \\
(116.1)\end{array}$ \\
\hline U.S. Fatalities & $\begin{array}{c}-0.386 \\
(0.170)^{* *}\end{array}$ & $\begin{array}{l}-0.015 \\
(0.169)\end{array}$ & $\begin{array}{c}-0.538 \\
(0.196)^{* *}\end{array}$ & $\begin{array}{l}-0.149 \\
(0.205)\end{array}$ & $\begin{array}{c}-0.744 \\
(0.222)^{* *}\end{array}$ & $\begin{array}{l}-0.189 \\
(0.255)\end{array}$ & $\begin{array}{c}-0.400 \\
(0.183)^{* *}\end{array}$ & $\begin{array}{l}-3.344 \\
(2.904)\end{array}$ & $\begin{array}{l}-2.117 \\
(3.266)\end{array}$ & $\begin{array}{l}-4.103 \\
(3.783)\end{array}$ & $\begin{array}{l}-5.477 \\
(8.786)\end{array}$ & $\begin{array}{l}-2.433 \\
(2.078)\end{array}$ & $\begin{array}{l}-8.367 \\
(23.92)\end{array}$ & $\begin{array}{c}-1.261 \\
(0.670)^{*}\end{array}$ \\
\hline \multicolumn{15}{|c|}{ Panel B: Mission Effectiveness Measured with Zero to One Index } \\
\hline $\begin{array}{l}\text { Index } \\
\text { of Success }\end{array}$ & $\begin{array}{c}2,578 \\
(753.8)^{* *}\end{array}$ & $\begin{array}{c}3,101 \\
(935.5)^{* *}\end{array}$ & $\begin{array}{c}1,913 \\
(790.6)^{* *}\end{array}$ & $\begin{array}{c}3,093 \\
(1,163)^{* *}\end{array}$ & $\begin{array}{c}1,045 \\
(673.4)^{* *}\end{array}$ & $\begin{array}{c}2,506 \\
(761.1)^{* *}\end{array}$ & $\begin{array}{c}2,608 \\
(769.5)^{* *}\end{array}$ & $\begin{array}{c}3,064 \\
(1,571)^{*}\end{array}$ & $\begin{array}{c}5,161 \\
(1,511)^{* *}\end{array}$ & $\begin{array}{c}3,029 \\
(1,266)^{* *}\end{array}$ & $\begin{array}{c}3,479 \\
(1,068)^{* *}\end{array}$ & $\begin{array}{c}3,756 \\
(1,884)^{* *}\end{array}$ & $\begin{array}{c}7,322 \\
(3,132)^{* *}\end{array}$ & $\begin{array}{c}3,197 \\
(1,317)\end{array}$ \\
\hline U.S. Fatalities & $\begin{array}{c}-0.626 \\
(0.202)^{* *}\end{array}$ & $\begin{array}{c}-0.421 \\
(0.270)\end{array}$ & $\begin{array}{c}-0.717 \\
(0.223)^{* *}\end{array}$ & $\begin{array}{c}-0.616 \\
(0.333)^{*}\end{array}$ & $\begin{array}{c}-0.842 \\
(0.206)^{* *}\end{array}$ & $\begin{array}{c}-0.615 \\
(0.272)^{* *}\end{array}$ & $\begin{array}{c}-0.618 \\
(0.208)^{* *}\end{array}$ & $\begin{array}{l}-1.227 \\
(0.783)\end{array}$ & $\begin{array}{l}-0.386 \\
(0.926)\end{array}$ & $\begin{array}{l}-0.664 \\
(0.686)\end{array}$ & $\begin{array}{c}-0.332 \\
(1.063)\end{array}$ & $\begin{array}{c}-0.838 \\
(0.431)^{*}\end{array}$ & $\begin{array}{c}-0.270 \\
(0.723)\end{array}$ & $\begin{array}{c}-1.087 \\
(0.640)^{*}\end{array}$ \\
\hline $\begin{array}{l}\text { Controls Include } \\
\text { Date \& } \\
\text { Continent } \\
\text { Air \& Enemy }\end{array}$ & $\begin{array}{l}\text { Yes } \\
\text { Yes }\end{array}$ & Yes & $\begin{array}{l}\text { Yes } \\
\text { Yes }\end{array}$ & Yes & $\begin{array}{l}\text { Yes } \\
\text { Yes }\end{array}$ & Yes & $\begin{array}{l}\text { Yes } \\
\text { Yes }\end{array}$ & $\begin{array}{l}\text { Yes } \\
\text { Yes }\end{array}$ & Yes & $\begin{array}{l}\text { Yes } \\
\text { Yes }\end{array}$ & Yes & $\begin{array}{l}\text { Yes } \\
\text { Yes }\end{array}$ & Yes & $\begin{array}{l}\text { Yes } \\
\text { Yes }\end{array}$ \\
\hline Terr \& Weath & Yes & Yes & Yes & Yes & Yes & Yes & Yes & Yes & Yes & Yes & Yes & Yes & Yes & Yes \\
\hline Human Fact & Yes & Yes & Yes & Yes & Yes & Yes & Yes & Yes & Yes & Yes & Yes & Yes & Yes & Yes \\
\hline $\mathrm{R}^{2}$ & -1.001 & -1.487 & -0.734 & -2.031 & -0.529 & -1.184 & -0.986 & -3.980 & -4.969 & -1.657 & -2.085 & -2.734 & -8.832 & -3.421 \\
\hline $\begin{array}{l}\text { Division Days } \\
\text { Engagements }\end{array}$ & $\begin{array}{l}279 \\
152\end{array}$ & $\begin{array}{l}279 \\
152\end{array}$ & $\begin{array}{l}251 \\
140 \\
\end{array}$ & $\begin{array}{l}251 \\
140 \\
\end{array}$ & $\begin{array}{l}234 \\
131 \\
\end{array}$ & $\begin{array}{l}234 \\
131 \\
\end{array}$ & $\begin{array}{l}278 \\
151\end{array}$ & $\begin{array}{l}289 \\
162 \\
\end{array}$ & $\begin{array}{l}289 \\
162 \\
\end{array}$ & $\begin{array}{l}252 \\
141\end{array}$ & $\begin{array}{l}252 \\
141 \\
\end{array}$ & $\begin{array}{l}239 \\
136 \\
\end{array}$ & $\begin{array}{l}239 \\
136 \\
\end{array}$ & $\begin{array}{l}288 \\
161 \\
\end{array}$ \\
\hline
\end{tabular}

Notes to Table A11: This table explores the sensitivity of the results by showing alternative specifications of the regressions in Table 2 . Additional details in the text. 
Table A12: Data Sources for U.S. Military Deaths in Division by Day Panel

\begin{tabular}{|c|c|c|c|c|}
\hline Dataset & Sample & Variables & Source & Citation \\
\hline $\begin{array}{l}\text { Reading } \\
\text { Room Data }\end{array}$ & $\begin{array}{l}\text { Battle dead among } \\
\text { those assigned to } \\
\text { U.S. Army ground } \\
\text { divisions. } \mathrm{N}=146,431\end{array}$ & $\begin{array}{l}\text { Name, serial number, division, } \\
\text { battalion or regiment, rank, broad } \\
\text { military occupational category, type } \\
\text { of death, date of death for } 41 \% \text { of } \\
\text { observations }\end{array}$ & $\begin{array}{l}\text { Hard copy } \\
\text { Xeroxed } \\
\text { from } \\
\text { Archives II } \\
\text { reading } \\
\text { room }\end{array}$ & $\begin{array}{l}\text { U.S. War } \\
\text { Department, } \\
1947\end{array}$ \\
\hline $\begin{array}{l}\text { U.S. } \\
\text { Airborne } \\
\text { Data }\end{array}$ & $\begin{array}{l}\text { Battle and non-battle } \\
\text { dead among those } \\
\text { assigned to U.S. } \\
\text { airborne divisions, } \\
\text { attachments included. } \\
\text { N=9,209 }\end{array}$ & $\begin{array}{l}\text { Name, division, battalion or regiment, } \\
\text { company, rank, type of death, country } \\
\text { of death, date of death, cemetery }\end{array}$ & $\begin{array}{l}\text { Downloaded } \\
\text { from } \\
\text { website. }\end{array}$ & $\begin{array}{l}\text { U.S. Airborne in } \\
\text { WWII, } 2010\end{array}$ \\
\hline $\begin{array}{l}\text { Machine } \\
\text { Records } \\
\text { Data }\end{array}$ & $\begin{array}{l}\text { Dead, wounded, } \\
\text { captured, or missing, } \\
\text { battle or non-battle, } \\
\text { all U.S. military } \\
\text { branches, 1941-1943, } \\
\mathrm{N}=101,353 \\
\end{array}$ & $\begin{array}{l}\text { Name, serial number, home county, } \\
\text { rank, broad category of military } \\
\text { occupation, type of casualty, date of } \\
\text { casualty }\end{array}$ & $\begin{array}{l}\text { Hard copy } \\
\text { Xeroxed } \\
\text { from } \\
\text { Archives II } \\
\text { records }\end{array}$ & $\begin{array}{l}\text { U.S. War } \\
\text { Department, } \\
1944\end{array}$ \\
\hline $\begin{array}{l}\text { WWII } \\
\text { Honor List }\end{array}$ & $\begin{array}{l}\text { All battle and non- } \\
\text { battle dead, all U.S. } \\
\text { military branches, } \\
\mathrm{N}=373,218\end{array}$ & $\begin{array}{l}\text { Name, serial number, rank, branch of } \\
\text { service, type of death, hometown }\end{array}$ & $\begin{array}{l}\text { FOIA } \\
\text { request to } \\
\text { ABMC }\end{array}$ & $\begin{array}{l}\text { U.S. Navy, 1946; } \\
\text { U.S. War } \\
\text { Department, } \\
1946\end{array}$ \\
\hline $\begin{array}{l}\text { ABMC } \\
\text { Cemetery } \\
\text { Files }\end{array}$ & $\begin{array}{l}\text { All battle and non- } \\
\text { battle dead buried in } \\
\text { U.S. military } \\
\text { cemeteries, all U.S. } \\
\text { military branches, } \\
\mathrm{N}=180,735 \\
\end{array}$ & $\begin{array}{l}\text { Name, serial number, branch of } \\
\text { service, divisional and } \\
\text { battalion/regiment affiliation, rank, } \\
\text { type of death, date of death, date of } \\
\text { birth, age, home town, burial plot } \\
\text { location, awards won }\end{array}$ & $\begin{array}{l}\text { Purchased } \\
\text { from ABMC }\end{array}$ & $\begin{array}{l}\text { U.S. American } \\
\text { Battle } \\
\text { Monuments } \\
\text { Commission, } \\
2005\end{array}$ \\
\hline $\begin{array}{l}\text { AGRS } \\
\text { Remains } \\
\text { not } \\
\text { Recovered } \\
\text { File }\end{array}$ & $\begin{array}{l}\text { All dead and missing } \\
\text { whose remains were } \\
\text { not recovered by } \\
1954 \text {, all U.S. } \\
\text { military branches, } \\
\mathrm{N}=79,021\end{array}$ & $\begin{array}{l}\text { Name, serial number, rank, branch of } \\
\text { service, date of loss }\end{array}$ & $\begin{array}{l}\text { FOIA } \\
\text { request to } \\
\text { DPMO }\end{array}$ & $\begin{array}{l}\text { U.S. Army } \\
\text { Graves } \\
\text { Registration } \\
\text { Service, } 1954\end{array}$ \\
\hline $\begin{array}{l}\text { WWII } \\
\text { Serials File }\end{array}$ & $\begin{array}{l}\text { Nearly all enlisted } \\
\text { U.S. Army personnel } \\
\text { who enrolled between } \\
1938 \text { and } 1946, \\
\mathrm{~N}=8,706,394\end{array}$ & $\begin{array}{l}\text { Name, serial number, home state and } \\
\text { county, enlistment location, date of } \\
\text { enlistment, rank, branch of service, } \\
\text { term of enlistment, country of birth, } \\
\text { year of birth, race and citizenship, } \\
\text { education, civilian occupation, marital } \\
\text { status, component of the Army }\end{array}$ & $\begin{array}{l}\text { Purchased } \\
\text { from NARA } \\
\text { Electronic } \\
\text { Records } \\
\text { Division }\end{array}$ & $\begin{array}{l}\text { U.S. National } \\
\text { Archives and } \\
\text { Records } \\
\text { Administration, } \\
2002\end{array}$ \\
\hline $\begin{array}{l}\text { Adjutant } \\
\text { General } \\
\text { Final } \\
\text { Report }\end{array}$ & $\begin{array}{l}\text { U.S. Army battle } \\
\text { casualties (incl. } \\
\text { wounded and } \\
\text { captured) and non- } \\
\text { battle deaths } \\
\mathrm{N}=936,259\end{array}$ & $\begin{array}{l}\text { Two-way tabulations include different } \\
\text { types of casualties and deaths by } \\
\text { division, by theater, and by month of } \\
\text { occurrence }\end{array}$ & $\begin{array}{l}\text { Hard copy } \\
\text { Xeroxed } \\
\text { from } \\
\text { Archives II } \\
\text { reading } \\
\text { room }\end{array}$ & $\begin{array}{c}\text { U.S. Army } \\
\text { Adjutant } \\
\text { General's Office, } \\
1953 .\end{array}$ \\
\hline
\end{tabular}


Table A13: Estimated Costs for a 1942 Organic Infantry and Armored Division

\begin{tabular}{rrrrr}
\hline & \multicolumn{2}{c}{ Infantry } & \multicolumn{2}{c}{ Armored } \\
& Initial & Monthly & Initial & Monthly \\
\hline & \multicolumn{2}{c}{ (expressed in millions of 2009 dollars) } \\
Enlisted \& Officer Pay & $\$ 233.45$ & $\$ 14.71$ & $\$ 236.33$ & $\$ 14.51$ \\
Enlisted \& Officer Training & $\$ 145.13$ & $\$ 0.19$ & $\$ 197.27$ & $\$ 0.31$ \\
& & & & \\
Major Divisional Equipment & $\$ 119.80$ & $\$ 4.30$ & $\$ 1,114.84$ & $\$ 71.00$ \\
& & & & \\
Food & $\$ 82.72$ & $\$ 3.27$ & $\$ 77.05$ & $\$ 3.08$ \\
Clothing & $\$ 58.02$ & $\$ 2.77$ & $\$ 54.35$ & $\$ 2.14$ \\
Additional Equipment & $\$ 36.40$ & $\$ 3.55$ & $\$ 34.17$ & $\$ 3.92$ \\
& & & & \\
Ammunition & $\$ 19.65$ & $\$ 7.98$ & $\$ 22.40$ & $\$ 19.24$ \\
Gasoline & $\$ 2.97$ & $\$ 1.25$ & $\$ 4.29$ & $\$ 3.85$ \\
Transportation & $\$ 280.18$ & $\$ 4.35$ & $\$ 500.10$ & $\$ 11.29$ \\
\hline Total & $\$ 978.34$ & $\$ 42.36$ & $\$ 2,240.78$ & $\$ 129.35$ \\
\hline \hline
\end{tabular}

Notes to Table A13: Compiled from various archival sources. Based on 1942 Tables of Organization and Equipment. In 1942, a standard infantry division included 15,514 troops and 0 tanks. In 1942, a standard armored division included 14,620 troops and 390 tanks.

Transportation includes inter- and intra-continental transport costs for troops and equipment. 